University of Nebraska - Lincoln

DigitalCommons@University of Nebraska - Lincoln

Publications of the US Geological Survey

US Geological Survey

2003

Sediment-Water Interactions Affecting Dissolved-Mercury

Distributions in Camp Far West Reservoir, California

James S. Kuwabara

U.S. Geological Survey, kuwabara@usgs.gov

Charles N. Alpers

U.S. Geological Survey, cnalpers@usgs.gov

Mark Marvin-DiPasquale

U.S. Geological Survey, mmarvin@usgs.gov

Brent R. Topping

U.S. Geological Survey, btopping@usgs.gov

James L. Carter

U.S. Geological Survey, jlcarter@usgs.gov

See next page for additional authors

Follow this and additional works at: https://digitalcommons.unl.edu/usgspubs

Part of the Earth Sciences Commons

Kuwabara, James S.; Alpers, Charles N.; Marvin-DiPasquale, Mark; Topping, Brent R.; Carter, James L.; Stewart, A. Robin; Fend, Steven V.; Parchaso, Francis; Moon, Gerald E.; and Krabbenhoft, David P., "Sediment-Water Interactions Affecting Dissolved-Mercury Distributions in Camp Far West Reservoir, California" (2003). Publications of the US Geological Survey. 53.

https://digitalcommons.unl.edu/usgspubs/53

This Article is brought to you for free and open access by the US Geological Survey at DigitalCommons@University of Nebraska - Lincoln. It has been accepted for inclusion in Publications of the US Geological Survey by an authorized administrator of DigitalCommons@University of Nebraska - Lincoln. 


\section{Authors}

James S. Kuwabara, Charles N. Alpers, Mark Marvin-DiPasquale, Brent R. Topping, James L. Carter, A. Robin Stewart, Steven V. Fend, Francis Parchaso, Gerald E. Moon, and David P. Krabbenhoft 
Sediment-Water Interactions Affecting Dissolved-Mercury Distributions in Camp Far West Reservoir, California

\section{U.S. GEOLOGICAL SURVEY}

Water Resources Investigations Report 03-4140
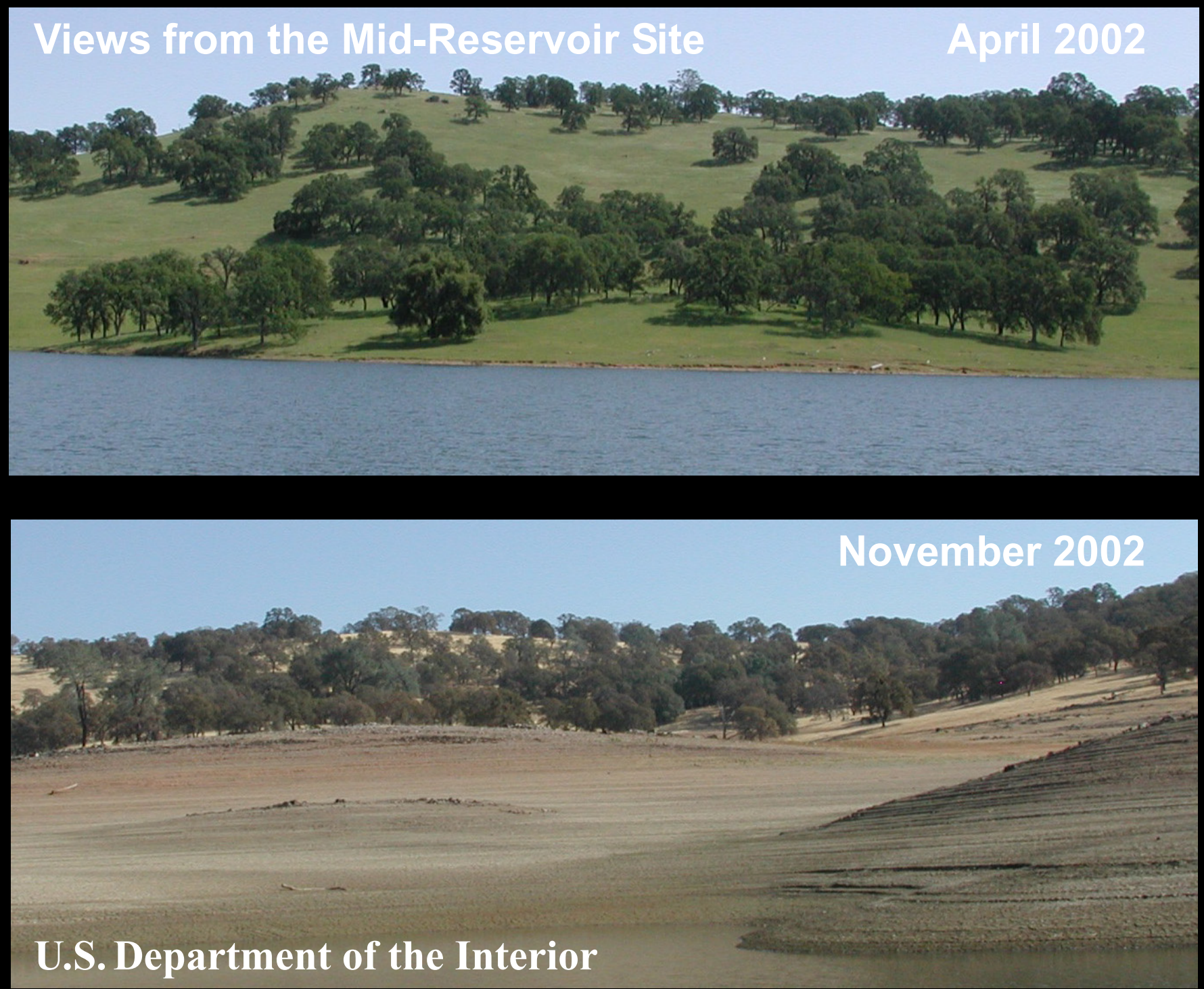

Internet access at: http://pubs.water.usgs.gov/wri03-4140/ 


\section{Sediment-Water Interactions Affecting Dissolved-Mercury Distributions in Camp Far West Reservoir, California}

By James S. Kuwabara ${ }^{1}$, Charles N. Alpers ${ }^{2}$, Mark Marvin-Dipasquale ${ }^{3}$, Brent R.Topping ${ }^{4}$, James L. Carter ${ }^{5}$, A. Robin Stewart ${ }^{6}$, Steven V. Fend ${ }^{7}$, Francis Parchaso ${ }^{8}$, Gerald E. Moon $^{9}$ and David P. Krabbenhoft ${ }^{10}$

\section{U.S. GEOLOGICAL SURVEY}

Water-Resources Investigations Report 03-4140

1 kuwabara@usgs.gov, U.S. Geological Survey, Menlo Park, CA

2 cnalpers@usgs.gov, U.S. Geological Survey, Sacramento, CA

3 mmarvin@usgs.gov, U.S. Geological Survey, Menlo Park, CA

4 btopping@usgs.gov, U.S. Geological Survey, Menlo Park, CA

5 jlcarter@usgs.gov, U.S. Geological Survey, Menlo Park, CA

6 arstewar@usgs.gov, U.S. Geological Survey, Menlo Park, CA

7 svfend@usgs.gov, U.S. Geological Survey, Menlo Park, CA

8 parchaso@usgs.gov, U.S. Geological Survey, Menlo Park, CA

9 gemoon@usgs.gov, U.S. Geological Survey, Menlo Park, CA

10 dpkrabbe@usgs.gov, U.S. Geological Survey, Middleton, WI 


\section{U.S. DEPARTMENT OF THE INTERIOR}

GALE A. NORTON, Secretary

U.S. GEOLOGICAL SURVEY

CHARLES G. GROAT, Director

For Additional Information

Write to:

James S. Kuwabara

U.S. Geological Survey

345 Middlefield Road, MS 439

Menlo Park, CA 94025
Copies of this report may be obtained from the authors or

U.S. Geological Survey Information Center Box 25286, MS 517 Denver Federal Center Denver, CO 80225 


\section{TABLE OF CONTENTS}

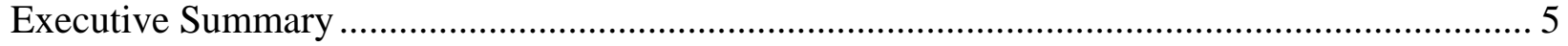

Physical and Biological Characterizations.................................................................... 6

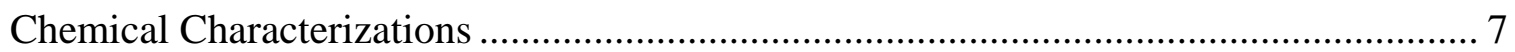

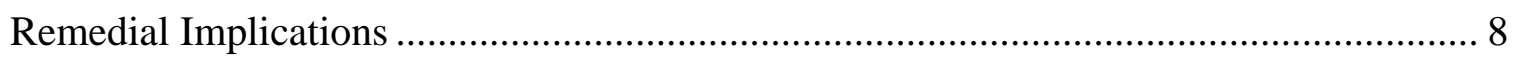

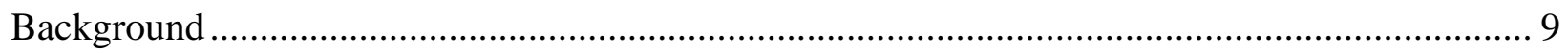

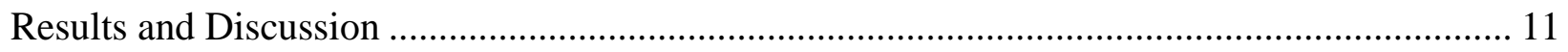

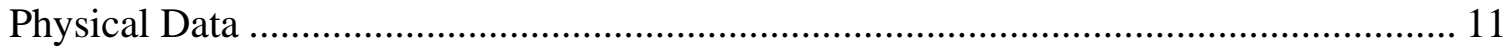

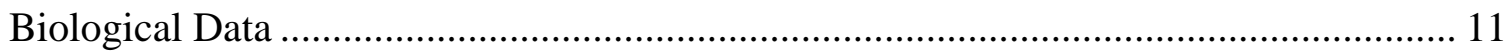

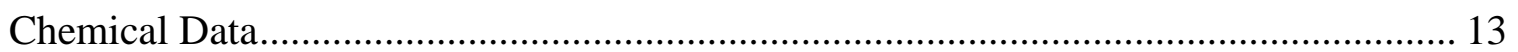

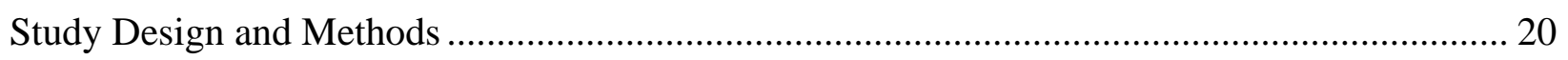

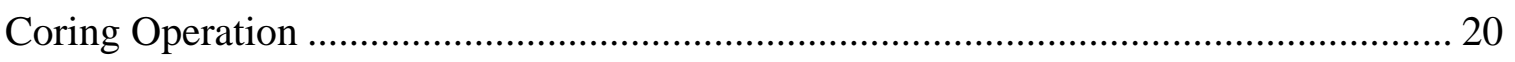

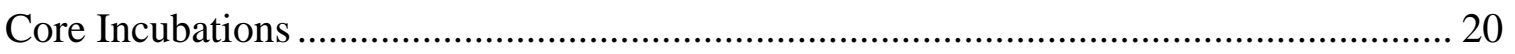

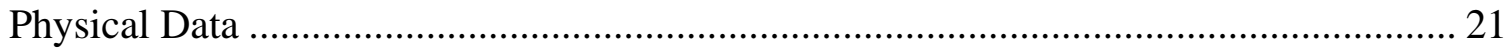

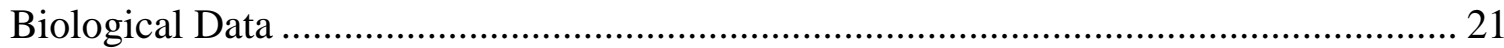

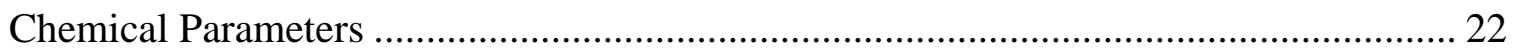

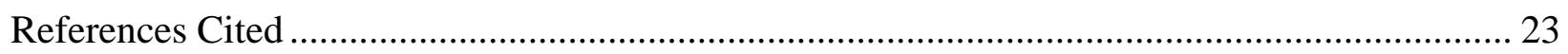

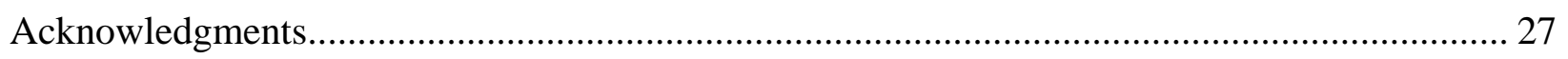

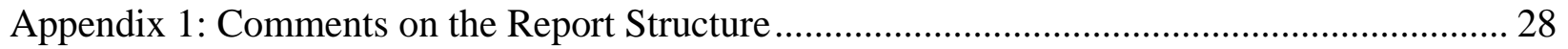

Appendix 2: List of Figures .................................................................................................. 29

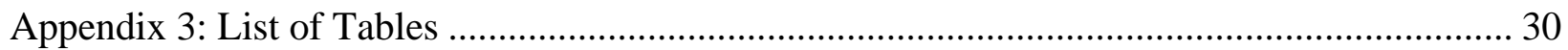




\title{
Sediment-Water Interactions Affecting Dissolved-Mercury Distributions in Camp Far West Reservoir, California
}

\author{
by James S. Kuwabara, Charles N. Alpers, Mark Marvin-Dipasquale, Brent R. Topping, \\ James L. Carter, A. Robin Stewart, Steven V. Fend, Francis Parchaso, \\ Gerald E. Moon and David P. Krabbenhoft
}

\section{Executive Summary}

Field and laboratory studies were conducted in April and November 2002 to provide the first direct measurements of the benthic flux of dissolved (0.2-micrometer filtered) mercury species (total and methylated forms) between the bottom sediment and water column at three sampling locations within Camp Far West Reservoir, California: one near the Bear River inlet to the reservoir, a second at a mid-reservoir site of comparable depth to the inlet site, and the third at the deepest position in the reservoir near the dam (herein referred to as the inlet, midreservoir and near-dam sites, respectively; Background, Fig. 1). Because of interest in the effects of historic hydraulic mining and ore processing in the Sierra Nevada foothills just upstream of the reservoir, dissolved-mercury species and predominant ligands that often control the mercury speciation (represented by dissolved organic carbon, and sulfides) were the solutes of primary interest. Benthic flux, sometimes referred to as internal recycling, represents the transport of dissolved chemical species between the water column and the underlying sediment. Because of the affinity of mercury to adsorb onto particle surfaces and to form insoluble precipitates (particularly with sulfides), the mass transport of mercury in mining-affected watersheds is typically particle dominated. As these enriched particles accumulate at depositional sites such as reservoirs, benthic processes facilitate the repartitioning, transformation, and transport of mercury in dissolved, biologically reactive forms (dissolved methylmercury being the most bioavailable for trophic transfer). These are the forms of mercury examined in this study.

In contrast to typical scientific manuscripts, this report is formatted in a pyramid-like structure to serve the needs of diverse groups who may be interested in reviewing or acquiring information at various levels of technical detail (Appendix 1). The report enables quick transitions between the initial summary information (figuratively at the top of the pyramid) and the later details of methods or results (figuratively towards the base of the pyramid) using hyperlinks to supporting figures and tables, and an electronically linked Table of Contents.

During two sampling events, two replicate sediment cores (Coring methods; Fig. 2) from each of three reservoir locations (Fig. 1) were used in incubation experiments to provide flux estimates and benthic biological characterizations. Incubation of these cores provided "snapshots" of solute flux across the sediment-water interface in the reservoir, under benthic, environmental conditions representative of the time and place of collection. Ancillary data, including nutrient and ligand fluxes, were gathered to provide a water-quality framework from which to compare the results for mercury. The following major observations from interdependent physical, biological, and chemical data were made: 


\section{Physical and Biological Characterizations}

1. Hydrologic Conditions: The sampling associated with this study occurred during one of the driest years on record for the area as depicted by the rapid draw down of the reservoir during our work in 2002 (Fig. 3; U.S. Geological Survey, 2003a). Outflows are regulated to provide for agricultural needs during the summer months, but so are inflows (for example, through Rollins Dam up stream of the reservoir). Historical outflow from the reservoir (represented by Bear River discharge data at Wheatland) before and after the dam construction in 1963 do not indicate marked differences (comparison of blue and green curves in Fig. 3) However, 2002 Wheatland discharge data indicates two pulses of increased flow before our April sampling trip, and an early reduction in discharge relative to historical averages following this trip. By the time of the second coring trip in November 2002, docking facilities for equipment and sample transfer were no longer available because of the 26-meter draw down (Fig. 4, see also the contrasting cover photographs). For example, the water-column depths (in meters) at the coring sites on April 5, 2002 were approximately 45, 25, and 28 for the near-dam, mid-reservoir and inlet sites, respectively. By November, reservoir draw down caused the depth at the near-dam site to decrease to 19 meters, and restricted our coring efforts at the inlet and mid-reservoir sites to positions as close to the April 2002 locations that the research vessel could safely navigate (approximately 2-meter depth; coordinates).

2. Shifts in Redox Gradients: Dissolved-oxygen (DO) and temperature profiles during the coring trips indicate that an increase in bottom-water temperatures between the trips coincided with a decrease in bottom-water dissolved-oxygen concentration at the deep near-dam site (Fig. 4). An oxycline was absent under more turbulent, high-flow spring conditions in April 2002. The water column maintained a distinct oxycline in November 2002 at the near-dam site despite the impressive draw down described in item 1 above.

3. Porosity: Porosity of the surficial sediments at the three coring sites was generally similar on both sampling trips. Cores from the mid-reservoir site exhibited the most substantial change in porosity between April 2002 (0.88 and 0.94) and November 2002 (0.65 and 0.68). Like the mid-reservoir site, elevated porosities were observed at the deep, near-dam site in April 2002 (0.96 and 0.98) relative to November ( 0.83 and 0.87 ). In contrast to the other two sites, the Bear River inlet site provided temporally consistent porosities (range of 0.84 to 0.90 ; Table 1 ).

4. Benthic Biota: Macroinvertebrate populations in the Camp Far West samples were considered to be of low importance to benthic flux (Table 2; Macrobenthos discussion). In other aquatic environments, the presence of certain macroinvertebrate taxa may exponentially increase the solute flux across the sediment-water interface due to biologically enhanced advection (Caffrey and others, 1996; Kuwabara and others, 1999a). In an oligotrophic system like Camp Far West Reservoir, however, densities of benthic macroinvertebrates are typically low relative to mesotrophic and eutrophic environments that have elevated primary (food) production (Brinkhurst, 2002). Macroinvertebrate densities from the Camp Far West Reservoir sites were consistently highest at the near-dam site and appear to be similar to those from other oligotrophic sites where benthic-flux determinations have been previously reported (Kuwabara and others, 2000; Kuwabara and others, 2001) (Fig. 5A). Benthic-chlorophyll concentrations mirrored the spatial pattern of macroinvertebrate densities during both coring trips with the highest concentrations at the near-dam site followed by the inlet site and the mid-reservoir site (Table 3; Fig. 5). 


\section{Chemical Characterizations}

Note: The dissolved-mercury concentrations discussed in this section refer to samples filtered with 0.7 -micrometer quartz-fiber filters pre-combusted at $500{ }^{\circ} \mathrm{C}$.

1. Dissolved mercury in the water column: Elevated bottom-water concentrations relative to the surface at the near-dam site are consistent with a benthic source of solute. For methyl-mercury, elevated bottom-water concentrations relative to the surface were not observed, in part due to the overall tightness in the concentration range as mentioned below (Mercury results).

Observed concentrations ranges for methyl-mercury (less than the detection of 0.20 picomolar to 0.50 picomolar, where picomolar units represent trillionths of a molar concentration) were tighter in magnitude than the range for total dissolved mercury concentrations (2.94 to 18.3 picomolar). The highest methyl-mercury concentrations in April 2002 were observed in the water column at the inlet site $(0.30 \pm 0.01$ picomolar $)$, whereas in November, the highest concentrations were in the bottom waters of the deep, near-dam site ( $0.48 \pm 0.03$ picomolar; Mercury results, Table 4$)$. Dissolved total mercury concentrations in the bottom waters of Camp Far West were significantly lower under the low-flow conditions of November 2002 relative to high flow in April 2002, but spatial trends were not temporally consistent. In terms of management implications, this contrast suggests a potentially important shift between a predominance of upstream sources of methylmercury under high-flow conditions, and internal methyl-mercury sources under low-flow conditions.

2. Benthic flux of dissolved forms of mercury: Estimates of riverine and benthic flux indicate that sediment sources of dissolved total mercury are seasonally variable, but consistently comparable to or greater in magnitude than riverine sources. Transport of dissolved, bioavailable mercury species between the reservoir bed and water column may therefore be a potentially critical process regulating the fate of mercury species in the reservoir water column (Mercury flux discussion).

Benthic fluxes for dissolved methyl mercury were: (1) generally positive in April 2002, (2) negligible at all sites in November 2002, and (3) at least two orders of magnitude lower than totalmercury fluxes, roughly consistent with concentration differences between species.

Similar to methyl-mercury fluxes, dissolved total-mercury fluxes, based on site averages from 2 replicate cores, were generally higher in April than in November 2002 (Table 5; Fig. 6). Fluxes of 36.3 and -28.4 picomoles per square meter per hour were measured in cores from the deep, neardam site which was suboxic in November, contrasting with positive fluxes of 306 and 272 picomoles per square meter per hour at that site in April 2002 when the bottom water was oxic (Fig. 4). All six measurements of total-mercury flux in April 2002 and five of six in November 2002 resulted in positive values (That is, out of the sediment into the overlying water column).

3. Benthic flux of nutrients, and mercury-binding ligands: The reservoir was highly phosphate limited with molar N:P ratios in water column samples ranging from 136 to $>5,000$ (compared to the Redfield N:P molar ratio of 16; Table 6). Minor (that is, submicromolar) changes in water-column concentrations can significantly alter the balance of limiting nutrients in an oligotrophic system like Camp Far West Reservoir. Because the flux of orthophosphate from bed sediments may be regulated by processes that control its adsorption and desorption onto metal-oxide surfaces (nutrient discussion; Kuwabara and others, 2003), sediment-water interactions may constrain orthophosphate flux relative to dissolved nitrogen species and thereby exacerbate phosphatelimiting conditions in the reservoir. 
Sulfide benthic fluxes were predictably highest $(1,180 \pm 50$ nanomoles per square meter per hour; Table 7) at the deep, near-dam site in November 2002 following at least 2 weeks of hypolimnetic anoxia (based on prior water-column monitoring), and lowest at the same near-dam site in April (290 \pm 30 nanomoles per square meter per hour) under high-flow, oxic conditions.

Consistent with sulfide fluxes, the highest benthic fluxes of dissolved organic carbon (DOC) were also observed at the deep, near-dam site in November 2002 (520 \pm 50 micromoles per square meter per hour; Table 8), and were consistently negative (consumed by the sediment) at the midreservoir site.

\section{$\underline{\text { Remedial Implications }}$}

Because the benthic flux of mercury species may represent a dominant transport process, it also suggests an important management implication. Remediation efforts and Total Maximum Daily Load (TMDL) allocations along the Bear River have dual objectives of decreasing concentrations and loads to down-gradient systems and reducing bioaccumulation of mercury in fish consumed by humans and wildlife. Using preliminary mercury-flux estimates into the reservoir from the Bear River, our results indicate that with considerable seasonal variability a significant (and possibly predominant) percentage of dissolved mercury in the water column presently comes from the reservoir bed (Mercury flux discussion). If upstream sources are controlled, which is desirable even apart from reservoir effects, the present inflow loads are likely to be compensated in part by increases in benthic flux (Fig. 7). Concentrations of total mercury in the reservoir should be expected to decrease slowly after inflow loads are controlled. A previously developed management tool (Kuwabara and others, 2003) was applied to estimate a benthic response to regulating the riverine inputs of contaminants to the reservoir. 


\section{Background \\ Why may sediment-water interactions be important factors affecting mercury distributions in Camp Far West Reservoir?}

Many fundamental processes affect the transport of dissolved chemical species (for example, nutrients, metals, ligands) through and within reservoirs and other aquatic systems. A conceptual model of these processes (Fig. 8) illustrates some physically based processes that have been examined and carefully quantified in a number of previous studies (for example, advective transport and point source inputs; Fisher and others, 1979).

There are, however, terms in the conceptual model that have until recently received little attention. A prime example is the benthic flux term where no direct measurements for dissolved mercury species have heretofore been available for the study area or other reservoirs in the Sierra Nevada. Benthic flux (sometimes referred to as internal recycling) represents the transport of dissolved chemical species between the water column and the underlying sediment. Flux of solutes can be either positive (into the water column from the sediment or atmosphere) or negative (out of the water column into the sediment or atmosphere) and can vary over multiple temporal and spatial scales (Kuwabara and others, 2002; Kuwabara and others, 2003).

As a result of physical, chemical, and biological processes operating near the sediment-water interface, geochemical gradients take on a variety of forms that have been previously reported and exemplified (Kuwabara and others, 2000; Fig. 9). Associated gradients in solute concentrations can thereby result in a benthic flux of that solute that may be negative or consumed by the sediment, positive or released from the sediment, or insignificant when the gradient is indistinguishable. When interdependent factors regulate the benthic flux of biologically reactive substances, the vertical gradient for one dissolved species may be dependent on the gradient of another chemical species. For example, an attenutated release may occur when solute concentrations increase below the sedimentwater interface only when another solute is depleted. Redox-sensitive solutes like dissolved iron often behaves in this manner when suboxic conditions reduce it from ferric to ferrous forms, increasing its solubility and releasing adsorbates. Macrofauna can also enhance benthic flux by irrigating, or perturbing surficial sediment layers (bioirrigation, bioturbation, or biologically enhanced advection). Certain productive benthic communities can enhance benthic flux by orders of magnitude beyond diffusive-control (Kuwabara and others, 1999a, Thibodeaux and Bierman, 2003), while other communities are too sparse to generate this magnitude of enhancement (Kuwabara and others, 2003). Therefore, vertical chemical gradients generated by a variety of interdependent biogeochemical processes can induce the transport of dissolved-mercury species across the sediment-water interface in lentic systems.

Scientists and water-quality managers are only beginning to appreciate the importance of benthic flux in many aquatic environments. Within the past decade or two, researchers have gradually realized that there are nonhydrologic processes (for example, benthic flux) that must be incorporated into water-quality models in order to generate physically meaningful information. Unfortunately, benthic-flux determinations are instrument and manpower intensive, because each flux estimate requires a concentration time-series analysis or vertical-profile analysis. Benthic-flux studies have consequently lagged behind studies of other transport processes, but are spurring interest in both the scientific and management communties (Kuwabara and others, 2003).

Water-quality managers often assess and prioritize remediation strategies for aquatic systems that have been adversely affected by anthropogenic activities. In the case of Camp Far West Reservoir along the Bear River, mercury associated with historic gold extraction has been fluvially transported and accumulated in the bottom sediments. Frequent demands have been made by regional managers and the general public to quantify the connections between fluxes of contaminants and the health, abundance, and distribution of biological resources (Kuwabara and others, 1999a). As part of a comprehensive examination of transport processes affecting mercury dynamics in Camp Far West Reservoir, this study focuses on a poorly understood, yet potentially predominant, source of mercury to the reservoir water column: internal recycling, or benthic flux of mercury species and associated ligands. Mobilization, flux, and biological availability of mercury into the water column of the reservoir are affected by physical (for example, advection and diffusion), chemical (that is, oxidation-reduction reactions, 
complexation and repartitioning) and biological processes (for example, bioirrigation and bioturbation)( Flegal and others, 1991; Kuwabara and others, 1996; Grenz and others, 2000, Topping and others, 2001).

The results described herein followed from the integration of current project studies with information needs identified by the California State Water Resources Control Board to provide initial determinations of dissolved total and methyl-mercury fluxes from the sediments into the water column of Camp Far West Reservoir. Recent mercury distribution and bioaccumulation studies at Camp Far West Reservoir and other reservoirs in the Bear River and Yuba River watersheds suggested the potential importance of sediment-water interactions in describing mercury speciation, transport and bioaccumulation (May and others, 2000). Quantifying and understanding the magnitude and variability of these interactions are critical to the accurate assessment of contaminant sources and loads as well as to the development of appropriate water-quality models and remedial programs for this mining-affected system.

With a wide a range of programmatic decisions to be made related to the improvement of water and fisheries resources in the Bear River, the question posed in this study was, "Are sources and sinks of dissolved total mercury and dissolved methyl-mercury associated with the bottom sediment within Camp Far West Reservoir significant relative to major surface-water inputs from the Bear River?” Various factors motivate this question. First, gold extraction upstream of the reservoir during the mid-nineteenth century provide a historic source of elemental mercury that continues to be fluvially transported in dissolved and particulate phases (Alpers and Hunerlach, 2000). Therefore, determining whether some fraction of this sediment-associated mercury can remobilize for transport to the overlying water and subsequently to downstream portions of the Bear River is of considerable environmental and ecological significance. Second, elevated concentrations of mercury species in reservoir water, sediment, and fish have prompted a compilation and comparison of dominant contaminant sources so that appropriate remedial strategies can be designed and implemented. Third, changes in oxidizing or reducing (redox) conditions, in $\mathrm{pH}$, and in nutrient availability near the sediment-water interface (for example, during phytoplankton blooms) can dramatically alter the mobility of metals and ligands associated with the bottom sediment as episodic sources of carbon settle out and accumulate (Thompson and others, 1981; Tessier and others, 1994). Finally, there is a growing body of evidence from other aquatic systems that benthic flux of contaminants and nutrients is an important process to consider in developing appropriate ecosystem water-quality models (Wood and others, 1995; Kuwabara and others, 2000). Thus, the need clearly exists for more refined conceptual and numerical models describing mercury dynamics within the Bear River system. 


\section{Physical Data}

\section{Results and Discussion}

Visually, there were general similarities in sediment texture among the three sampling sites. At all sites, the cores were characterized by a bright orange (iron-oxide like), unconsolidated surficial layer overlying a dark gray to black mud. That surficial layer was most prominent in the April 2002 sample and had a thickness greater than 2 centimeters. Given that core penetration depths were only approximately 10 centimeters to provide core volume for overlying water, sedimentcore retrieval was facilitated by the compacted silts and clays below the surficial layers (Unconsolidated or sandy material below surficial layers tend to cause a greater frequency of core material loss during retrieval). Porosity of the bottom sediment ranged from 0.65 at the midreservoir site in November 2002 to 0.98 at the near-dam site in April 2002 (Table 1). The lowest porosities ( 0.65 and 0.68$)$ at the mid-reservoir site in November were coincident with the gradual filling of the reservoir after significant summer draw down. This generated rewetted, fractured bottom sediment reminiscent of the summer-exposed, compacted bank sediment.

\section{$\underline{\text { Biological Data }}$}

1. Benthic macroinvertebrates: In certain aquatic environments, bioturbation and bioirrigation by benthic macroinvertebrates can significantly affect the benthic flux of solutes (Charbonneau and Hare, 1997; Kuwabara and others, 1999a). At Camp Far West Reservoir, the benthic macroinvertebrates were spatially and temporally dominated by immature tubificid worms (Table 2). Typically, immature tubificids are not quantitatively retained by 500 -micrometer sieving. Reible and others (1996) reported that the flux of hydrophobic organics can be significantly increased when large, laboratory-cultured tubificids are present at densities between 6,000 to 27,000 per square meter. Not only were the densities of tubificids in Camp Far West Reservoir cores typically much lower, but they were also dominated by smaller, immature individuals (Table 2). Biologically enhanced benthic flux through bioirrigation or bioturbation would not be expected from such low biomass of the benthic assemblage at the time of coring.

The average number of individuals in the benthic assemblage was similar between sampling dates

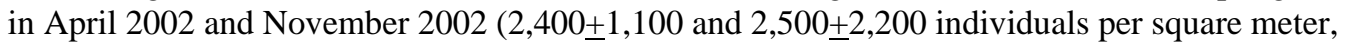
respectively). However, there were significant differences in the densities between sites (Fig. 5A). On both sampling dates, the lowest macroinvertebrate densities were found in the mid-reservoir sites, followed by Bear River inlet site, and highest densities at the deep, near-dam site. It is notable that the highest macroinvertebrate densities were observed at the near-dam site in November 2002 when the highest benthic chlorophylls were also measured, but also when the lowest dissolved-oxygen concentrations were present following at least 2 weeks of hypolimnetic anoxia. Immature tubificids, like those that dominated the benthic assemblage (Table 2), have demonstrated tolerance to extended exposures (of the order of months) of suboxic and anoxic conditions (Jenderedjian, 1994; Rieradevall and Real, 1994; Smith, 2001).

In summary, the low biomass of the benthic community at the coring sites suggest that there were insufficient biota to generate biologically enhanced benthic flux through bioirrigation or bioturbation. Macroinvertebrate communities were dominated by very small immature tubificid worms and nematodes that typically pass through a conventional 500-micrometer mesh sieve. This is consistent with low benthic-chlorophyll concentrations particularly at the inlet and midreservoir sites (see section below and Fig. 5B), and with sulfide-flux determinations. However, other lines of evidence such as bromide injections or radon emanation would be required to confirm that bioturbation effects in the reservoir are negligible (Kuwabara and others, 2003). 
2. Benthic chlorophyll-a: Chlorophyll- $a$ concentrations in surficial sediments ranged from 0.3 to 3.2 micrograms per square centimeter with highest concentrations observed at the near-dam site during the fall sampling (November 2002), and the lowest concentrations at the mid-reservoir site during the spring sampling (April 2002) (Table 3). Benthic biological data from our study and previously published data from other oligotrophic lakes (Fig. 5B; Kuwabara and others, 2002; Kuwabara and others, 2003) clearly indicated that the benthic algal biomass was sparse at all three coring sites and thus indicative of oligotrophic systems. Benthic chlorophylls in Camp Far West Reservoir (overall mean of $1.45 \pm 0.86$ micrograms per square centimeter; Fig. $5 B$ ) are representative of low concentrations expected in an oligotrophic environment (Fig. 5B). The spatial distributions, coincident with those for macroinvertebrate densities, suggest a food limitation in trophic pathways. The concentration ratio of chlorophyll- $a$ to chlorophyll- $a$ plus phaeo-pigments (CCP ratio) is used as a crude indicator of the extent of senescence in an algal population (Thompson and others, 1981; Kuwabara and others, 1990). Ratios greater than 0.5 indicate active growth, and values less than 0.5 suggest enhanced pigment degradation associated with cell senescence or predation pressures that process the chlorophyll- $a$ to degradation products. The overall benthic CCP ratio for this study was $0.12 \pm 0.04(\mathrm{n}=36)$, indicating a predominance of degraded or biologically processed chlorophyll- $a$.

Like Camp Far West Reservoir, sediment quality in San Francisco Bay is also affected by historic mining and ore processing in the Sierra Nevada (Jaffe and others, 1998). However unlike Camp Far West Reservoir, the benthic CCP ratio is much more variable in San Francisco Bay sediments $(0.20 \pm 0.19 ; n=414)$ because ratios greater than 0.3 and as high as 0.9 are associated with phytoplankton bloom periods in the northern and southern components of the estuary (Thompson and others, 1981). Compared to benthic measurements, bottom waters of San Francisco Bay display higher CCP ratios $(0.50 \pm 0.14 ; n=330$ from January 1999 ; water-quality database query at http://sfbay.wr.usgs.gov). The consistently low benthic CCP ratio at Camp Far West suggests a consistently senescent benthic community and therefore perhaps a primary planktonic source at least during our sampling periods.

3. Surface-water chlorophyll-a: Chlorophyll-a concentrations in the surface water (1-meter depth) ranged seasonally from low values of 1.6 to 5.0 micrograms per liter $\left(\mu \mathrm{g}-\mathrm{L}^{-1}\right)$ in the spring and summer (April and August 2002) to the higher values of 4.4 to $30.4 \mu \mathrm{g}^{-\mathrm{L}^{-1}}$ in the fall and winter (October 2001, February and November 2002, January 2003) (Table 9, Figure 10A). Marked differences among stations within the reservoir were observed in the fall of 2001 and 2002 and in January of 2003 with chlorophyll- $a$ concentrations significantly decreasing from the inlet to the near-dam sites, except for January 2003 when concentrations were lowest at the inlet. These chlorophyll- $a$ concentrations are similar to those found in other reservoirs in California and Canada (Paterson and others, 1997; U.S. Geological Survey, 2003b) and surface waters of San Francisco Bay/Delta. Pheophytin pigments, which are markers of chlorophyll degradation, followed a similar seasonal cycle (Table 9, Figure 10B). Ingestion of algal cells by zooplankton and microherbivores results in the decomposition of chlorophyll pigments and the formation of pheophytins (Wetzel, 2001). Planktonic CCP ratios, which have been used as a coarse indicator of grazing by zooplankton, were consistently higher than observed in the benthic-chlorophyll samples (refer to previous section), and increased from 0.75 in the fall of 2001 to 0.90 in April of 2002, then declined to 0.65 in August of 2002 and remained relatively constant through January 2003 (Table 9, Figure 10C). These elevated water-column CCP ratios indicate that zooplankton grazing was not a significant removal mechanism for chlorophyll from the water column. Furthermore, it does not appear that the zooplankton community exerted significant grazing pressure on the phytoplankton stock. 
4. Stable isotope and elemental composition of suspended particulate matter (SPM): Carbon isotopic ratios $\left(\delta^{13} \mathrm{C}\right)$ of the SPM were similar among stations and ranged from $-34 \%$ in February 2002 to $-28 \%$ in April 2002 (Table 9, Figure 11A). Nitrogen isotopic ratios $\left(\delta^{15} \mathrm{~N}\right)$ of the SPM were more variable among stations and ranged from a high of 10.64 in February 2002 to a low of 1.94 in April 2002 (Table 9, Figure 11B). These patterns of enriched nitrogen isotopic values coincident with depleted carbon isotopic values are typical of the water column in freshwater lakes (Vander Zanden and Rasmussen, 1999). The combination of surface-water chlorophyll-a concentrations and elemental and isotopic composition of the SPM suggests that the water column of Camp Far West Reservoir is a dominant source of production for the pelagic food web and possibly the benthic food web.

\section{Chemical Data}

For consistency with previous geochemical studies, mercury flux estimates were determined in mass-flux units, but were also tabulated in molar units.

1. Dissolved oxygen (DO) benthic flux: Dissolved-oxygen fluxes were consistently negative at the deep, near-dam site, indicating benthic consumption, but were variable in direction at the shallower upstream sites. DO flux ranged from -503 micromoles per square meter per hour at the inlet site in April 2002 (average of two measurements, $n=8$ ) to 306 micromoles per square meter per hour at the mid-reservoir site on the same date (Table 10). A comparison of average dissolved-oxygen flux measurements for the three sites indicates that the mid-reservoir site was the only site to display positive fluxes in one of two cores in both April and November 2002. No temporal or spatial variations in oxygen consumption at the inlet or the deep, near-dam sites were observed. With higher bottom-water temperatures (Fig. 4) and lower dissolved oxygen at the near-dam site in November 2002, significantly higher oxygen consumption at this site was expected relative to April 2002, but this was not observed (Table 10). A partial mixing of the water column and transition from hypolimnetic anoxia to suboxia within 2 to 3 weeks of the November 2002 sampling may explain this result. A temporal comparison of water-column profiles for DO and temperature at the inlet and mid-reservoir sites is not applicable here because of the reservoir draw down. At these shallower depths (approximately 2-meter depth) the temperature and DO profiles were uniform. As with mercury-flux measurements, 95-percent confidence intervals were often greater than the mean flux value despite acceptable coefficients of determination because only a single analytical replicate from each of four time intervals was used in the linear-regression for flux determinations and hence the confidence interval is based on only two degrees of freedom (confidence interval discussion). More extensive follow up studies would warrant greater analytical replication, including at least three core replicates per site to better quantify small-scale (within site) variability.

2. Dissolved mercury in reservoir bottom waters: At all three sampling sites, higher dissolved totalmercury concentrations (Table 4; Fig. 12) were observed in April (three-site mean: $16.7 \pm 2.0$ picomolar $\{\mathrm{n}=11\})$ relative to November $(4.6 \pm 2.2\{\mathrm{n}=10\})$. These values include initial concentrations in the core overlying water. This difference may reflect the insolubility of mercury in the presence of elevated sulfide concentrations associated with the hypolimnetic anoxia and suboxia in November. This temporal trend was not observed for methyl-mercury in the bottom waters with overall means for April and November of $0.24 \pm 0.09(n=12)$ and $0.28 \pm 0.13$ picomolar ( $\mathrm{n}=11$ ), respectively. In April, 2002, the inlet site displayed the highest methyl-mercury concentrations for bottom waters $(0.33 \pm 0.06$ picomolar; $\mathrm{n}=4)$ relative to the other two downstream sites $(0.19 \pm 0.06$ picomolar, $n=8)$. In contrast, November 2002 results indicate the 
highest methyl-mercury concentrations in the reservoir bottom waters at the deep, near-dam site $(0.48 \pm 0.03$ picomolar, $\mathrm{n}=3)$ relative to the two other upstream sites (all replicates $<0.20$ picomolar, $\mathrm{n}=8$ ). This contrast and the negligible benthic fluxes for methyl-mercury at all three sites suggest a possible switch between the dominance of allochthonous (external or upstream) methyl-mercury sources during high flow and autochthonous (internal including) sources during low flow. By comparison, higher concentrations for dissolved mercury species were observed in the bottom waters of Lahontan Reservoir in Nevada, another reservoir affected by historic gold mining (range of methyl-mercury from 0.3 to 1.1 picomolar and of total dissolved mercury from 613 to 2,068 picomolar; Kuwabara and others, 2002).

Although available concentration data for dissolved total mercury near the surface of Camp Far West Reservoir are limited, near-surface concentrations were routinely lower than bottom-water concentrations. In April 2002, near-surface (3-meter depth) and bottom-water concentrations at the near-dam site for dissolved total mercury were 4.5 picomolar (with an analytical error of \pm 0.5 picomolar) and $17.5 \pm 1.2$ picomolar ( $\mathrm{n}=2$, Table 4), respectively. Elevated bottom-water concentrations relative to the surface is consistent with a benthic source of solute. Vertical gradients for methyl-mercury in the water column were indistinguishable.

3. Mercury benthic flux: Dissolved total-mercury fluxes were positive (that is, out of the bed sediment) in all six incubated cores in April 2002 and five of six cores in November 2002. Dissolved totalmercury fluxes were greatest at the mid-reservoir site in April 2002. The lowest benthic fluxes were at the deep, near-dam site in November, coincidently when the highest sulfide fluxes were observed (Table 5). Given lower solubility of mercury in the presence of sulfides (Hogfeldt, 1983), a redox barrier to dissolved-mercury benthic flux may have been generated.

In contrast to total-dissolved mercury, none of the three sites generated a significant benthic flux for methyl-Hg in November, and in April 2002, the inlet site actually generated a negative flux (Table 5). Dissolved methyl-mercury fluxes were highest at the mid-reservoir site in April 2002 $(0.6 \pm 0.1$ picomoles per square meter per hour). It should be noted that the imposed shift in the sampling locations for the inlet and mid-reservoir sites (that is, the effects of the draw down) to some extent confound temporal with spatial comparisons at those two upstream sampling locations. Variability in microbial activity and transformation rates for mercury species at these sites may also contribute to observed differences. Measurement of potential mercury transformation (methylation and demethylation) rates were incorporated into the overall study of this reservoir but are not yet available. For both sampling dates, the magnitude of the methylmercury fluxes were at least two orders of magnitude less than the flux estimates for total mercury, roughly consistent with concentration differences between species.

A summary of mercury-flux data from Camp Far West Reservoir and Lahontan Reservoir along the Carson River (Fig. 6), illustrates that flux estimates not only vary over orders of magnitude, but also vary in direction where a positive flux represents solute transport into the water column, and a negative flux indicates solute moving from the water column to the sediment or to the atmosphere. The core-incubations were used to estimate benthic-flux over the projected area of Camp Far West Reservoir for the two sampling dates (2.5 and 1.3 square kilometers in April and November 2002, respectively), and ranged between -1.0 to 0.5 and 3.9 to 300 picomoles mercury per square meter per hour for methyl and total mercury, respectively, using the mean of two replicate cores per site. This corresponds to a mass range of -5 to 3 and 19 to 1,440 nanograms mercury per square meter per day for methyl and total mercury, respectively. Riverine fluxes into the reservoir for the two sampling dates were based on stream-flow data available on the Internet up to October 2002 (USGS, 2003) and provisional data from the Nevada Irrigation District for October through November 2002, the first two months of the 2003 Water Year. In addition, dissolved total and methyl-mercury data near the surface (3-meter depth) from the inlet site was 
used as an estimate of the inflow concentration. For April 24 and November 4, 2002, the riverine fluxes were estimated at 0.9 and 0.4 nanograms methyl mercury per square meter per hour, and 52 and 36 nanograms total dissolved mercury per square meter per hour, respectively. Thus, based on our initial benthic and riverine flux estimates for dissolved mercury species, the reservoir bed appears to represent a significant source of dissolved mercury to the water column, but that importance is at least seasonally and spatially variable. An analysis of total-mercury and methylmercury fluxes into and out of Camp Far West Reservoir, based on monthly water-quality sampling during water years 2000 to 2003 will be published separately. Additional work to quantify flux variability over various spatial and temporal scales would be recommended in order for this benthic source to be quantitatively incorporated into mercury-transport, water-quality models for the reservoir.

Gustin (cited in Kuwabara and others, 2002) estimated an elemental-mercury emission from Lahontan Reservoir, Nevada, within the Carson River SuperFund site, at 4 nanograms mercury per square meter per hour. Corresponding mercury emissions have not been made at Camp Far West Reservoir, but given that total dissolved-mercury concentrations in the water column of Camp Far West Reservoir are two orders of magnitude lower than Lahontan Reservoir, and the surface area is an order of magnitude lower than Lahontan Reservoir (20 to 40 square kilometers; Katzer, 1971), it is reasonable to speculate that mercury release to the atmosphere from Camp Far West Reservoir is also lower than from Lahontan Reservoir in units of flux or load. On the basis of our current comparative information, it would seem prudent to consider benthic processes when trying to quantitatively describe mercury-transport processes within and through this reservoir.

Errors presented in the text and each of the tables represent 95-percent confidence intervals about the mean value unless otherwise specified. In the case of the dissolved-mercury, nutrient and oxygen fluxes, elevated confidence intervals relative to the flux estimate seem inconsistent with the goodness of fit to the linear regression (only one core with a coefficient of determination < 0.79 for total-mercury flux). This inconsistency is due to the limitation of a single, qualitycontrolled concentration from each of four time intervals being used for the linear regression to determine benthic flux from each core. Therefore, only two degrees of freedom remain after the slope and mean are determined. The confidence interval is therefore elevated above the standard deviation because a value from the t-distribution in the numerator increases nonlinearly as the degrees of freedom decrease. Because these results represent the first estimates of mercury benthic flux from Camp Far West Reservoir, cost efficiency in replication of mercury analytical data relative to spatial and temporal coverage was a primary consideration. In future studies, greater replication of mercury-speciation data at each time interval during the core incubation would be required to decrease the confidence limits. However, the high coefficients of determination and general consistency between cores from this study reflect positively on the reported fluxes.

\section{Dissolved trace metals in the water column (Application of a management tool): Increased}

concentrations at depth relative to surface waters may indicate a positive flux of a solute from the sediment into the water column. Dissolved-metal concentrations for cadmium (Cd), cobalt (Co), copper $(\mathrm{Cu})$, iron $(\mathrm{Fe})$, lead $(\mathrm{Pb})$, manganese $(\mathrm{Mn})$, nickel $(\mathrm{Ni})$, vanadium $(\mathrm{V})$, and zinc $(\mathrm{Zn})$ in the water column were determined as ancillary parameters to investigate the potential for significant benthic flux (Fig. 13, Table 11). As previously discussed, the shallow November 2002 depths precluded any water-column profiling for the mid-reservoir and inlet stations, and thus any temporal comparisons for these two sites. At the near-dam site, concentrations for most metals increased throughout the water column between the sampling dates. This general increase may be explained by: (1) evaporation leading to concentration of the solutes, or (2) seasonal changes in inflow controlled upstream (for example, at Rollins Dam). However, the variability in the magnitude of the increases between individual metals suggests that repartitioning dynamics (for 
example anoxia-induced reducing conditions) might be controlling some concentrations. For $\mathrm{Zn}$ and $\mathrm{Pb}$, bottom water concentrations in November were an order of magnitude greater than bottom water concentrations in April (Table 11). Also, the ratio of bottom water to surface water concentrations (labeled "temporal ratio" in Table 11) rose significantly ( $>8$ times) for $\mathrm{Zn}$ and $\mathrm{Pb}$ between sampling dates. Considering the near-anoxic bottom water at the near-dam site in November, it is likely that reducing conditions caused these trends for $\mathrm{Zn}$ and $\mathrm{Pb}$. Some metals ( $\mathrm{Cd}, \mathrm{V}, \mathrm{Fe}$ ) showed smaller increases in this ratio ( 1.5 times), while others ( $\mathrm{Cu}$ and $\mathrm{Ni}$ ) showed temporal decreases in both this ratio and bottom-water concentrations. Also, the November data shows that the maximum concentration for most metals was observed at the depth just above the oxycline. These data indicate that further water-column profiling and benthic flux experiments would be needed to determine the potential significance of benthic flux in determining trace metal distributions in the reservoir.

The consistent increase in dissolved-zinc concentrations near the sediment-water interface of Camp Far West Reservoir (as mentioned above, and similar to those observed for dissolvedmercury species) suggests a benthic source of zinc and poses an interesting management implication. Assuming that the observed water-column gradients for dissolved zinc resulted from diffusion from the reservoir-bed, a benthic flux for zinc can be estimated for April 2002, in the absence of an oxycline, and for November 2002, under dissolved-oxygen stratification. The zinc benthic flux (0.04 and 21 micromoles per square meter per hour, respectively; Table 12) is based on the eddy diffusivity of zinc near the reservoir bed, as reflected in the zinc concentrations of the lentic water column (Kuwabara and others, 1999b). Applying those estimates for zinc benthic flux with an assumed diffusion coefficient $\left(1 \times 10^{-5}\right.$ square centimeters per second; Li and Gregory, 1974) and a diffusion-layer thickness of 2 centimeters (Kuwabara and others, 2002), pore-water zinc concentrations for April and November can be "back calculated" ( 0.25 and 120 micromolar, respectively; Table 12) using the standard expression for diffusion as described and applied by Berelson and others (1982). Kuwabara and others (2003) described a management tool to examine the effects of regulating upstream fluvial loads of contaminants. If the bottom-water and estimated pore-water concentrations for dissolved zinc are plotted relative to other mining-affected sites that have been previously examined, it would appear, at least for this zinc example, that April 2002 results would not motivate upstream remedial action because both pore-water and bottomwater concentrations were low relative to the other lake and reservoir environments. The November 2002 results highlight the need to consider benthic flux of contaminants under these conditions in order to appropriately evaluate the effectiveness of upstream remediation, because benthic flux remains a dominant transport process with or without implemented remediation (Fig. 14). Although desirable, data are not currently available to make analogous site comparisons for mercury to examine the indirect effects of upstream remediation.

5. Nutrients in the water-column (The concept of a limiting nutrient): In an oligotrophic system like Camp Far West Reservoir, ostensibly subtle shifts in solute concentrations can alter the balance of nutrients that regulate phytoplankton growth (that is, primary production in the water column). The molar nitrogen to phosphorus (N:P) ratio for assimilation by primary producers like phytoplankton is approximately 16 (often referred to as the Redfield N:P ratio; Wetzel, 2001). Dissolved-nutrient concentrations in the water column strongly indicate phosphate limiting conditions in the reservoir with dissolved N:P molar ratios ranging from 136 to 5,191, with nine of ten values of the ratio at least an order of magnitude greater than the Redfield ratio (Table 6). Molar carbon to nitrogen (C:N) ratios of the suspended particulate matter declined from approximately 8 in October 2001 to 6.4 in February of 2002 and increased back to 8 in April of 2002 (Table 9, Figure 11C) following seasonal trends in phytoplankton abundance. These C:N molar ratios are typical of phytoplankton-dominated suspended particulate matter (that is, similar to the Redfield C:N molar ratio of 6.7) and consistent with the notion that neither carbon nor nitrogen was limiting phytoplankton growth in the reservoir. Furthermore, Wetzel (2001) 
summarized that a molar $\mathrm{C}: \mathrm{N}$ ratios less than 8.3 indicate no nitrogen limitation, an observation that supports measured phosphate-limiting conditions in the reservoir water column (Table 6).

Because orthophosphate has a high affinity to repartition to metal-oxide surfaces and algal cells (Goldberg, 1985; Kuwabara and others, 1986), one might hypothesize that sediment-water interactions may play a significant role in regulating these nutrient limitations (see item 5 below). As reducing conditions facilitate the reduction of iron from ferric to ferrous form which has greater solubility, the dissolution of hydrous iron oxides releases adsorbed orthophosphate. During our two sampling dates, suboxic bottom-water conditions were only observed at the deep, near-dam site in November 2002. It is therefore notable that for that location and time, the oxic surface-water N:P molar ratio was at the highest observed value of 5,191, but the near-anoxic bottom water (approximately 1 milligram dissolved oxygen per liter), displayed an N:P molar ratio that was an order of magnitude lower at 569. This order-of-magnitude difference above and below the oxycline was generated by increased bottom-water orthophosphate, not a water-column gradient in dissolved nitrogen concentration (Table 6).

6. Nutrient benthic flux: Forms of dissolved inorganic nitrogen (ammonia, nitrate, and nitrite) had a consistently positive flux in the reservoir (i.e., out of the sediment into the overlying water column) except at the mid-reservoir site in April 2002 (Table 6). The overall average for dissolved inorganic nitrogen flux for April and November 2002 was 74 and $143 \mu \mathrm{moles}-\mathrm{m}^{-2}-\mathrm{h}^{-1}$, respectively. The corresponding averages for orthophosphate for April and November 2002 were -0.16 and $0.29 \mu$ moles $-\mathrm{m}^{-2}-\mathrm{h}^{-1}$. These average fluxes generate $\mathrm{N}: \mathrm{P}$ ratios of -470 and 486 for April and November 2002, respectively (both conditions lead to absolute values that are an order of magnitude greater than the Redfield ratio described above). The flux of orthophosphate from bed sediments may be regulated by processes that control its adsorption and desorption onto metal-oxide surfaces (Kuwabara and others, 2003). For both April and November, sediment-water interactions may therefore constrain orthophosphate flux relative to dissolved nitrogen species and thereby exacerbate phosphate-limiting conditions in the reservoir, as discussed in item 5 above.

In aquatic systems where phytoplankton assemblages are dominated by diatoms, benthic fluxes of silica are used to estimate the dissolution of biogenic bed material. Silica fluxes determined for Camp Far West Reservoir were anomalous because they exhibited fluxes that were not consistently positive (that is, sediment consumption of dissolved silica was measured in certain cores during both incubation experiments; Table 6). The conventional assumption that diatom frustules are the major silica source to the surficial bed sediment may be incorrect for Camp Far West Reservoir. Nutrient data also indicated anomalous results for Core 5 from the mid-reservoir site in April 2002, reflected in the highly nonlinear time series for all solutes except silica. There were no visual indications of irregular characteristics in that core or in the core's incubation that explained the disparate response. It would be strongly recommended that the incubation of at least three cores per site be used in subsequent studies for more quantitative understanding of smallscale (within site) variability (Kuwabara and others, 2003). As with mercury-flux measurements, 95-percent confidence intervals about mean values were often greater than the mean despite acceptable coefficients of determination because only a single analytical replicate from each of four time intervals was used in the linear-regression for flux determinations (confidence interval discussion).

7. Dissolved organic carbon (DOC): DOC concentrations serve as an indicator of the presence of organic ligands that can complex and enhance the solubility of trace metals including mercury. The partitioning and speciation of certain metals in aquatic systems are significantly affected by organic complexation (Mantoura and others, 1978; McKnight and others, 1983), and this effect is particularly important for mercury. Ligands represented by dissolved organic carbon can compete with sulfide to regulate mercury solubility (see section 8 below, Ravichandran and others, 1998) 
and can also decrease the bioavailability of mercury to certain aquatic biota (Sjoblom and others, 2000). In April 2002, water-column DOC concentrations were highest at the near-dam site and were uniform with depth (184.3 to 185.8 micromolar; Table 8). At both upstream sites, a middepth minimum in DOC was observed with the lowest concentration at the inlet site $(126.2 \pm 2.5$ micromolar). In contrast to the April 2002 results, the lowest DOC concentration in November 2002 was observed in bottom waters of the near-dam site $(187.0 \pm 2.6)$, yet that lowest concentration was higher than concentrations from April 2002. Higher DOC at all sites in November relative to April 2002 is consistent with temporal trends observed at Lahontan Reservoir in Nevada, another mining affected reservoir (Kuwabara and others 2001). This temporal increase in the fall was probably caused by one or more of the following: snow-melt dilution (leading to lower DOC levels during April), a source of DOC available during the fall within the watershed, temporal changes in mass transport through the reservoir, or evaporation. In contrast to our observed seasonal-scale trends, Yan and others (1996) hypothesized that long-term (decadal) drought conditions and associated draw down at Swan Lake on the Canadian Precambrian shield caused reoxidation of exposed bank-sediment sulfur, resulting in acidification and decreased DOC concentrations in the lake water column. In April 2002, total dissolved mercury concentration in the oxic bottom waters of Camp Far West Reservoir was highest at the deep near-dam site (17.5 \pm 1.2 picomolar) coincident with the highest bottom-water DOC concentration (184.3 \pm 0.7 micromolar; Table 8$)$. This solute interdependency is also consistent with concentration trends observed at Lahontan Reservoir (Kuwabara and others 2001). DOC serves as a ligand to enhance the dissolution of cinnabar (mercury sulfide, HgS), and hence increase mercury solubility and mobility (Ravichandran and others, 1998). It should be noted, however, that the direct relationship between bottom-water mercury and DOC did not hold at the deep, near-dam site in November 2002, when the bottom water was suboxic (following weeks of hypolimnetic anoxia).

The benthic flux of DOC ranged from -169 micromoles per square meter per hour at the midreservoir site in April 2002 (average of two flux measurements, $n=32$ analytical measurements) to 518 micromoles per square meter per hour at the deep, near-dam site in November 2002 (Table 8). Negative DOC fluxes (that is DOC consumed by the sediment) has been reported, but is atypical (Caffrey and others, 1996). For both sampling dates, the highest measured DOC fluxes out of the sediment were at the near-dam site, followed by the Bear River inlet site. DOC benthic flux at the mid-reservoir site was consistently negative (consumed by the sediment).

8. Dissolved Sulfide: Sulfide flux was consistently positive (that is, from the sediment to the overlying water column) and ranged from 290 to 1,180 nanomoles per square meter per hour (average of two replicates per site per date; Table 7). A spatial comparison of dissolved-sulfide benthic fluxes indicates the highest fluxes at the deep, near-dam site in November 2002 relative to the other two upstream sites. Given anoxic or suboxic conditions prior to and during our November 2002 sampling, this observation is not surprising (Fig. 4). Conversely in April 2002, sulfide flux at the deep site was lowest among the three sites. As with porosities, the sulfide fluxes at the most upstream Bear River inlet sites were temporally consistent. At the mid-reservoir sites, higher sulfide flux in November 2002 relative to April 2002 was coincident with bed sediment in November of lower surficial porosity (albeit fractured from rewetting).

Using dissolved-sulfide concentrations from the bottom water and surficial porewater, a diffusive flux from the benthos was calculated with a diffusion coefficient of $1 \times 10^{-5}$ square centimeters per second (Li and Gregory, 1974). The calculated diffusive-flux estimates were consistently lower than directly measured sulfide-fluxes and 4 out of 6 diffusive-flux measurements were an order of magnitude or more lower (Table 7). These differences between measured and calculated fluxes are curious and in need of further study because benthic biological measurements indicate that the reservoir had insufficient biomass of critical macroinvertebrate species to impose bioturbation or 
bioirrigation effects. Benthic macroinvertebrate densities have been linked to relative enhancement of benthic flux in other mining-affect aquatic systems (Caffrey and others, 1996; Kuwabara and others, 1999a; Kuwabara and others 2001; Kuwabara and others 2003; Thibodeaux and Bierman, 2003).

Dissolved sulfide represents a metastable ligand in most surficial environments which has a high affinity to complex most divalent metals. This sulfide-complexing effect is particularly strong for mercury, which has a logarithmic mercuric-sulfide solubility product of approximately -50 (Hogfeldt, 1983). At thermodynamic equilibrium, the product of the molar concentrations of uncomplexed mercury and uncomplexed sulfide ions is therefore expected to be very low (of the order of $10^{-50}$ ) due to the formation of mercuric sulfide. As the presence of DOC facilitates the dissolution or desorption of particle-associated mercury, and subsequent flux of dissolved mercury species, the presence of sulfides can conversely facilitate precipitation and decreased solubility of mercury, inhibiting benthic flux. 


\section{Study Design and Methods}

The protocol described in this section focuses on method applications in this series of two core-incubation experiments. Details (for example, quality control specifications) for each analysis have been previously documented (Woods and others, 1999; Praskins and others, 2001; Kuwabara and others, 2003). Sampling was performed at three sites: a near inlet site (Fig. 1) (Map index 1, 39 degrees 2.039 minutes north latitude by 121 degrees 16.409 minutes west longitude), a mid-reservoir site (Map index 2; 39 degrees 2.677 minutes $\mathrm{N}$ by 121 degrees 17.433 minutes $W$ ), and site near the dam at the deepest position in the reservoir (Map index 3;39 degrees 3.140 minutes $\mathrm{N}$ by 121 degrees 18.687 minutes $\mathrm{W}$ ). Because of significant draw down in the reservoir during the summer (Fig. 4), the inlet and mid-reservoir sites were sampled as close to the April 2002 sites as safely accessible by the sampling vessel (2 meter depth). These adjusted coordinates for the upstream sites in November 2002 were 39 degrees 2.124 minutes $\mathrm{N}$ by 121 degrees 16.939 minutes $\mathrm{W}$, and 39 degrees 2.525 minutes $\mathrm{N}$ by 121 degrees 17.498 minutes $\mathrm{W}$ for the inlet and mid-reservoir sites, respectively. Horizontal coordinate information is referenced to the North American Datum of 1983 (NAD 83). Cores were taken during the morning to avoid the effects of wind on core retrieval and sediment resuspension, and to facilitate the transport of cores to the incubation site. The site map (Fig. 1) also depicts reservoir outflow regulated at the Camp Far West Dam and regulated inflow from the Bear River inlet to the east.

As porosity measurements indicate (Table 1), the interface between the reservoir bed and the overlying water column is characteristically a layer of extremely soft (unconsolidated) sediment $1-10$ centimeters thick that contains 65 to 95 percent water by volume. This intimate mixture of solid and liquid facilitates chemical and biological processes that move chemicals between solid and solution. Particularly under spring, high-flow conditions, this unconsolidated surficial layer (overlying more compacted silts and clays) can be readily resuspended and transported to depositional areas near the dam. Similar materials are found in other lentic settings (Kuwabara and others, 2000).

\section{Coring Operation}

On both sampling days (April 24 and November 4, 2002), three cores were collected at each of three sites using a 28-kilogram coring device fabricated from non-metallic parts (ig. 2, Savillex Corporation, Minnetonka, Minnesota). To avoid sample contamination, wetted surfaces of the coring device and core tubes were acid-washed polypropylene or fluoroethylene polymer. Cores were collected in 10-centimeter diameter fluoroethylene polymer tubes 28-centimeters long. A tube, mounted on the coring device, was dropped onto the sediment by gravity, impacting the surface at about 0.2 meters per second and penetrating about 10 centimeters (depending on the porosity). Excessive penetration by the core was mitigated by four radially positioned, cylindrical weights that acted as stabilizers (or feet) for the device. This sampling protocol was designed to provide minimal disturbance or compression of soft sediments as visually verified by: (1) the presence oxic sediment $(<3$ centimeters in thickness, often of brown or orange color) overlying gray to black anoxic sediment, (2) the presence of macroinvertebrates and their tubes, and (3) minimal resuspension of surficial sediment in the overlying water when the core was retrieved. If the sampler captured at least 2 centimeters of compacted silt or clay below the surficial layer, the sampler generally could be retrieved with the core and overlying water intact. Some samples were lost during retrieval, probably because the lowest sampled material was sandy or otherwise unconsolidated.

Immediately after retrieval, the bottom and top of the sample tube were capped with an insert on the bottom and a screw cap on the top (both made of fluoroethylene polymer). The tubes were stored upright in a padded plastic container containing ice.

\section{Core Incubations}

After cores were collected, samples were taken to Menlo Park, California for processing. Cores were left overnight to equilibrate with wetted surfaces. Core incubations then began with the replacement of overlying water with bottom water that had been pumped from each site. Disturbance of the cores during handling was monitored by comparison of the chemical composition of the overlying water at the beginning of the incubation with bottom 
waters. Significant deviations in the composition of these water samples would indicate significant disturbance of the core during processing.

Bottom water was aerobic on both sampling dates at the inlet and mid-reservoir sites. The twelve cores taken at those sites were aerated overnight to condition wetted surfaces before the incubation period (Topping and others, 2001). Although bottom water at the deep near-dam site was also aerobic in April, 2002, it was clearly suboxic (that is, less than 5 micromolar dissolved oxygen) in November, 2002. The April cores from this site were processed as described above for the other two sites, but the November samples from near-dam site were placed in argon-purged and argon-filled bags during transport and incubation to avoid inadvertent aeration of the overlying

water. Two of the three cores per site were selected for incubation on the basis of visual inspection of the sedimentwater interface for any disturbances. Water overlying the sediment in the selected cores was sampled at four time intervals during a12-hour incubation at the bottom-water temperature. Overlying water sampled from the cores was replaced by pumped bottom water from the site where the core was collected. A linear regression of the time series of solute concentrations was used to determine the benthic flux (slope of the time series) from each of the incubated cores.

\section{Physical Data}

Sediment Porosity: After core incubations, approximately 10 milliliters of surficial sediment was collected from each core (top 3 centimeters) using a modified 10-cubic centimeter syringe. Wet weight and dry weight after lyophilization were measured to calculate porosity (Table 1).

\section{Biological Data}

1. Benthic Macroinvertebrates: After core incubations, each core was sieved (500-micrometer mesh). The sieved samples were fixed with 10-percent buffered formalin, later transferred to 70-percent ethanol, then sorted at 10× magnification and identified to the lowest practicable taxonomic level (Fig. 15). Samples were stained with rose bengal to facilitate sorting. No subsampling was used.

2. Benthic Chlorophyll-a: Each incubated core was sub-sampled in triplicate for benthic chlorophyll-a. Surficial sediment (top 0.5 centimeters) was collected on a glass-fiber filter and buffered with magnesium carbonate. Samples were then frozen in darkness for preservation until spectrophotometrically analyzed by methods described in Thompson and others (1981) and Franson (1985) (Fig. 16).

3. Stable isotope and elemental composition of suspended particulate matter (SPM): Water samples for chlorophyll-a, suspended particulate material (SPM), and elemental and stable isotopic carbon $(\mathrm{C})$ and nitrogen $(\mathrm{N})$ analyses were collected 1 meter below the surface using a van Dorn water sampler and filtered through a 210-micron plastic (Nitex) mesh to remove coarse particulates. Replicate water samples $(\mathrm{n}=2)$ were filtered within 2 hours of collection onto 25-millimeterdiameter and precombusted 13-millimeter-diameter glass-fiber filters and frozen on dry ice. SPM on 13-millimeter-diameter filters were fumed in a desiccator with $\mathrm{HCl}$ to remove carbonates, and filters were placed in tin capsules and held in a desiccator until analyzed for carbon and nitrogen isotopes. Chlorophyll-a concentrations were determined on 25-millimeter-diameter filters fluorometrically (Eaton and others, 1995) within 6 months of collection.

Isotope ratios and $\mathrm{C}$ and $\mathrm{N}$ concentrations of the SPM was determined at the Stable Isotope facility, Department of Agronomy and Range Science, University of California, Davis, using a Europa Scientific Hydra 20/20 continuous flow isotope ratio mass spectrometer and Europa ANCA-SL elemental analyzer to convert organic $\mathrm{C}$ and $\mathrm{N}$ into $\mathrm{CO}_{2}$ and $\mathrm{N}_{2}$ gas. All samples were standardized against Pee Dee Belemnite (C) or $\mathrm{N}_{2}$ in air. The following example (for nitrogen) indicates how an isotopic ratio is calculated:

$$
\delta^{15} \mathrm{~N} \% \text { o }=\left[\left(\mathrm{R}_{\text {sample }} / \mathrm{R}_{\text {standard }}\right)-1\right] \times 1000
$$


where $\mathrm{R}={ }^{15} \mathrm{~N} /{ }^{14} \mathrm{~N}$. Instrument precision was 0.1 percent for carbon and 0.3 percent for nitrogen on a per mil basis, based on replicate analyses of standard reference materials.

\section{Chemical Parameters}

1. Bottom-water sampling: Prior to coring at each sampling site, bottom-water samples (approximately 1 meter above the sediment-water interface) were collected for subsequent analysis of dissolvedmercury speciation by cold-vapor atomic fluorescence spectroscopy (CVAFS) using a highdisplacement peristaltic pump and a tethered length of rigid fluoroethylene polymer tubing. These samples were also used to replace overlying water in cores collected from each site for incubation.

2. Dissolved Oxygen (DO): Concentrations of dissolved oxygen were monitored for each incubated core using a micro-Winkler titration method (Fig. 17; Kuwabara and others, 2000).

3. Dissolved Mercury and Methyl Mercury: Dissolved-mercury and methyl mercury samples were processed in a Class-100 laminar-flow hood. Samples from water-column sampling, and core incubations were filtered with 0.7 -micrometer quartz membranes that had been baked for 6 hours at 500 degrees centigrade to remove residual organics. Filtered samples were acidified with quartz-distilled nitric acid ( $\mathrm{pH}$ less than 2), and refrigerated in darkness until analyzed by CVAFS (Fig. 18, Krabbenhoft and others, 1998). Methodological details were reported by DeWild and others (2002).

4. Dissolved Trace Metals by ICP-MS: Water-column samples were also collected, filtered (0.2micrometer polycarbonate membrane) and acidified to provide dissolved trace-metal information for the reservoir by inductively coupled plasma mass spectrometry (Creed and others, 1994; Fig. 19)

5. Dissolved nutrients: Nutrient samples were filtered ( 0.2 micron polycarbonate membranes) and immediately refrigerated in darkness. Unlike trace-metal samples, nutrient samples were not acidified. Concentrations for dissolved (0.2-micron filtered) nitrate, ammonia, orthophosphate and silica were determined by automated spectrophotometry (ig. 20).

6. Dissolved organic carbon (DOC): Dissolved organic carbon was determined by high-temperature, noncatalytic combustion (Qian and Mopper, 1997). Potassium phthalate was used as the standard. Low-DOC water (blanks $<40$ micrograms-organic carbon per liter) was generated from a doubledeionization unit with additional ultraviolet treatment (Milli-Q Gradient, Millipore Corporation) (Fig. 21).

7. Sulfide: Dissolved sulfides in overlying-water samples were analyzed by square-wave voltammetry (Fig. 22; Kuwabara and Luther, 1993). 


\section{References Cited}

Alpers, C.N., and Hunerlach, M.P., 2000, Mercury contamination from historic gold mining in California: U.S. Geological Survey Fact Sheet FS-061-00, 6 p. (Internet access at: http://ca.water.usgs.gov/mercury/fs06100.html).

Bass, D., 1992, Colonization and succession of benthic macroinvertebrates in Arcadia Lake, a South-Central USA reservoir: Hydrobiologia, v. 242, no. 2, p. 123-131.

Berelson, W. M., Hammond, D. E., and Fuller, C.C., 1982, Radon-222 as a tracer for mixing in the water column and benthic exchange in the southern California borderland: Earth and Planetary Science Letters, v. 61, p. 41-54.

Brinkhurst, R.O., 2002, The Benthos of Lakes, The Blackburn Press, Caldwell, New Jersey, 190 p.

Caffrey, J.M., Hammond, D.E., Kuwabara, J.S., Miller, L.G., and Twilley, R.R., 1996, Benthic processes in San Francisco Bay: the role of organic inputs and bioturbation, in Hollibaugh, J.T., ed., San Francisco Bay: the Ecosystem: American Association for the Advancement of Science, Pacific Division, San Francisco, p. 425-442.

Carroll, R.W.H., and Warwick, J.J., 2001, Uncertainty analysis of the Carson River mercury transport model: Ecological Modelling, v. 137, p. 211-224.

Carroll, R.W.H., Warwick, J.J., Heim, K.J., Bonzongo, J.C., Miller, J.R., and Lyons, W.B., 2000, Simulation of mercury transport and fate in the Carson River, Nevada: Ecological Modelling, v. 125, no. 2-3, p. 255-278.

Charbonneau, P., Hare, L., and Carignan, R., 1997, Use of X-ray images and a contrasting agent to study the behavior of animals in soft sediments: Limnology and Oceanography, v. 42, p. 1823-1828.

Creed, J.T., Brockhoff, C.A., and Martin, T.D., 1994, Determination of trace elements in waters and wastes by inductively coupled plasma-mass spectrometry, Method 200.8, Revision 5.4: U. S. Environmental Protection Agency, 61 p. (Internet access at: http://www.epa.gov/oamcinc1/0112125/200-8.pdf)

DeWild, J.F., Olson, M.L., and Olund, S.D., 2002, Determination of Methyl Mercury by Aqueous Phase Ethylation, Followed by Gas Chromatographic Separation with Cold Vapor Atomic Fluorescence Detection: Open-File Report 01-445 (Internet access at: http://wi.water.usgs.gov/pubs/ofr-01-445/ofr-01-445.pdf).

Eaton, A.D., Clesceri, L.S., and Greenberg, A.E. 1995. Standard methods for the examination of water and wastewater. American Public Health Association.

Fischer, H.B., List, E.J., Koh, R.C.Y., Imberger, J., and Brooks, N.H., 1979, Mixing in Inland and Coastal Waters: Academic Press, Inc., Orlando, Florida, 483, p.

Flegal, A.R., Smith G.J., Gill, G.A., Sanudo-Wilhelmy, S.A., Scelfo, G.M., and Anderson, L.C.D., 1991, Dissolved trace element cycles in the San Francisco Bay estuary: Marine Chemistry, v. 36, p. 329-363.

Franson, M.A.H., 1995, Standard methods for the examination of water and wastewater, Sixteenth Edition, Method 1003C.6: American Public Health Association, American Water Works Association, Water Pollution Control Federation, Washington, D.C., 1268 p.

Goldberg, S.A., 1985, Chemical modeling of anion competition on goethite using the constant capacitance model: Soil Science of America Journal, v. 49, p. 851-856.

Grenz, C., Cloern, J.E., Hager, S.W., and Cole, B.E., 2000, Dynamics of nutrient cycling and related benthic nutrient and oxygen fluxes during a spring phytoplankton bloom in South San Francisco Bay (USA): Marine Ecology Progress Series, v. 197, p. 67-80.

Hoffman, R.J., and Taylor, R.L., 1998, Mercury and suspended sediment, Carson River Basin, Nevada, - Loads to and from Lahontan Reservoir in flood year 1997 and deposition in reservoir prior to 1983: U. S. Geological Survey Fact Sheet FS-001-98, 6 p.

Hogfeldt, E., 1983, Stability constants of metal-ion complexes. Part A, Inorganic ligands. Pergamon Press, Oxford. $310 \mathrm{p}$.

Imberger, J., 1998, Flux paths in a stratified lake: A review, in Imberger, J., ed., Coastal and Estuarine Studies: Physical Processes in Lakes and Oceans: American Geophysical Union, v. 54, p. 1-17.

Jaffe, B.E., Smith, R.E., and Torresan, L.L., 1998, Sedimentation and bathymetric change in San Pablo Bay, 18561983: U.S. Geological Survey Open-File Report 98-759 (Internet access at: http://geopubs.wr.usgs.gov/open-file/of98-759/). 
Jenderedjian, K., 1994, Population dynamics of Potamothrix alatus paravanicus Poddubnaya and Partaridze (Tubificidae) in different areas of Lake Swan: Hydrobiologia, v. 278, p. 281-286.

Katzer, T.L., 1971, Reconnaissance bathymetric map and general hydrology of Lahontan Reservoir, Nevada: U.S. Geological Survey and U.S. Bureau of Reclamation Water Resources Information Series, Report 9.

Krabbenhoft, D.P., Gilmour, C.C., Benoit, J.M., Babiarz, C.L., Andren, A.W., and Hurley, J.P., 1998, Methyl mercury dynamics in littoral sediments of a temperate seepage lake: Canadian Journal of Fisheries and Aquatic Sciences, v. 55, p. 835-844.

Kuwabara, J.S., Davis, J.A., and Chang, C.C.Y., 1986, Algal growth response to particle-bound orthophosphate and zinc: Limnology and Oceanography, v. 31, p. 503-511.

Kuwabara, J.S., Chang, C.C.Y., and Pasilis, S.P., 1990, Effects of benthic flora on arsenic transport: Journal of Environmental Engineering, v. 116, p. 394-409.

Kuwabara, J.S., and Luther, G.W., III, 1993, Dissolved sulfides in the oxic water column of San Francisco Bay, California: Estuaries, v. 16, p. 567-573.

Kuwabara, J.S., Chang, C.C.Y., Khechfe, A.I., and Hunter, Y.R., 1996, Implications of dissolved sulfides and organic substances for the chemical speciation of trace contaminants in the water column of San Francisco Bay, California, in Hollibaugh, J.T., ed., San Francisco Bay: the Ecosystem: American Association for the Advancement of Science, Pacific Division, San Francisco, p. 157-172.

Kuwabara, J.S., Topping, B.R. Coale, K.H., and Berelson, W.M., 1999a, Processes affecting the benthic flux of trace metals into the water column of San Francisco Bay, In Morganwalp, D.W., and Buxton, H.T., eds., U.S. Geological Survey Toxic Substances Hydrology Program--Proceedings of the Technical Meeting, Charleston, South Carolina, March 8-12, 1999--Volume 2--Contamination of Hydrologic Systems and Related Ecosystems: U.S. Geological Survey Water-Resources Investigations Report 99-4018B, p. 115119 (Internet access at: http://toxics.usgs.gov/pubs/wri994018/Volume2/sectionA/2214_Kuwabara/index.html).

Kuwabara, J.S., van Geen, A., McCorkle, D.C., and Bernhard, J.M., 1999b, Dissolved sulfide distributions in the water column and sediment pore waters of the Santa Barbara Basin: Geochimica et Cosmochimica Acta, v. 63, no. 15, p. 2199-2209.

Kuwabara, J.S., Berelson, W.M., Balistrieri, L.S., Woods, P.F., Topping, B.R., Steding, D. J., and Krabbenhoft, D.P., 2000, Benthic flux of metals and nutrients into the water column of lake Coeur d'Alene, Idaho: Report of an August, 1999 Pilot Study: USGS Water-Resources Investigations Report 00-4132, 74 p. (Internet access at: http://water.usgs.gov/pubs/wri/wri004132/).

Kuwabara, J.S., Marvin-Dipasquale, M.M., Praskins, W., Byron, E., Topping, B.R., Carter, J.L., Fend, S.V., Parchaso, F., and Krabbenhoft, D.P., 2002, Flux of dissolved forms of mercury across the sediment-water interface in Lahontan Reservoir, Nevada: U.S. Geological Survey Water Resources Investigations Report 02-4138, 48 p. (Internet access at: http://water.usgs.gov/pubs/wri/wri024138/).

Kuwabara, J.S., Woods, P.F., Berelson, W.M., Balistrieri, L.S., Carter, J.L., Topping, B.R., and Fend, S.V., 2003, Importance of sediment-water interactions in Coeur d'Alene Lake, Idaho: Management Implications: Environmental Management, v. 32, in press.

Lewis, W.M., Jr., 1982, Vertical eddy diffusivities in a large tropical lake: Limnology and Oceanography, v. 27, p. 161-163.

Li, Y.H., and Gregory, S., 1974, Diffusion of ions in sea water and in deep-sea sediments: Geochimica et Cosmochimica Acta, v. 38, p. 703-714.

Mantoura, R.F.C., Dixon, A., and Riley, J.P., 1978, The complexation of metals with humic materials in natural waters: Estuarine and Coastal Marine Sciences, v. 6, p. 387-408.

Marvin-DiPasquale, M.M., and Oremland, R.S., 2001, Methyl-mercury formation and degradation in sediments of the Carson River system: U.S. Geological Survey Administrative Report to U.S. Environmental Protection Agency, Region IX, 69 p.

May, J.T., Hothem, R.L., Alpers, C.N., and Law, M.A., 2000, Mercury bioaccumulation in fish in a region affected by historic gold mining: The South Yuba River, Deer Creek, and Bear River Watersheds, California, 1999: U.S. Geological Survey Open-File Report 00-367, 30 p. (Internet access at: http://ca.water.usgs.gov/archive/reports/ofr00367/index.html). 
McKnight, D.M., Feder, G.L., Thurman, E.M., Wershaw, R.L., and Westall, J.C., 1983, Complexation of copper by aquatic humic substances from different environments: Science of the Total Environment, v. 28, p. 65-76.

Miller, D.C., 1984, Mechanical post-capture particle selection by suspension- and deposit-feeding Corophium: Journal of Experimental Biology and Ecology, v. 82, p. 59-76.

Mortimer, C.H., 1942, The exchange of dissolved substances between mud and water in lakes: Journal of Ecology, v. 30, p. 147-201.

Paterson, M. J., Findlay, D., Beaty, K. G., Findlay, W., Schindler, E. U., Stainton, M. P., and McCullough, G., 1997, Changes in the planktonic food web of a new experimental reservoir: Canadian Journal of Fisheries and Aquatic Sciences, v. 54, p. 1088-1102.

Popp, A., and Hoagland, K.D., 1995, Changes in benthic community composition in response to reservoir aging: Hydrobiologia, v. 306, no. 1, p. 159-171.

Qian, J.-G., and Mopper, K., 1996, Automated high-performance, high-temperature combustion total organic carbon analyzer: Analytical Chemistry, v. 68, p. 3090-3097.

Ravichandran, M., Aiken, G.R., Reddy, M.M., and Ryan J.N., 1998, Enhanced dissolution of cinnabar (mercuric sulfide) by dissolved organic matter isolated from the Florida Everglades: Environmental Science and Technology, v. 32, p. 3305-3311.

Reible, D.D., Popov, V., Valsaraj, K.T., Thibodeaux, L.J., Lin, F., Dikshit, M., Todaro, M.A., and Fleeger, J.W., 1996, Contaminant fluxes from sediment due to tubificid oligochaete bioturbation: Water Research, v. 30, no. 3, p. 704-714.

Rieradevall, M., and Real, M., 1994, On the distribution patterns and population dynamics of sublittoral and profundal oligochaeta fauna from Lake Banyoles (Catalonia, NE Spain): Hydrobiologia, v. 278, p. 139149.

Smith, D.G., 2001, Pennak's Freshwater Invertebrates of the United States: Porifera to Crustacea: John Wiley and Sons, New York, New York, 638 p.

Sjöblom, Å., Meili, M., and Sundbom, M., 2000, The influence of humic substances on the speciation and bioavailability of dissolved mercury and methyl-mercury, measured as uptake by Chaoborus larvae and loss by volatilization: The Science of the Total Environment, v. 261, p. 115-124.

Tessier, A., Carignan, R., and Belzile, N., 1994, Processes occurring at the sediment-water interface: Emphasis on trace elements, In Buffle, J. and DeVitre, R.R., eds., Chemical and Biological Regulation of Aquatic Systems: Lewis Publishers, Boca Raton, Florida, p. 137-173.

Thibodeaux, J.L., and Bierman, V.J., 2003, The bioturbation-driven chemical release process: Environmental Science and Technology, v. 37, no. 13, p. 251A-261A.

Thompson, J.K., Nichols, F.H., and Wienke, S.M., 1981, Distribution of benthic chlorophyll in San Francisco Bay, California, February 1980 - February 1981: U.S. Geological Survey Open File Report 81-1134, 55 p.

Topping, B.R., Kuwabara, J.S., Parchaso, F., Hager, S.W., Arnsberg, A.J., and Murphy, F., 2001, Benthic flux of dissolved nickel into the water column of South San Francisco Bay: U.S. Geological Survey Open-file Report 01-89, 50 p. (Internet access at: http://pubs.water.usgs.gov/ofr01089/).

U.S. Geological Survey, 2003, National Water Information System (NWIS),

a. Bear River near Rollins Dam near Colfax, California and Bear River near Wheatland, California, http://water.usgs.gov/ca/nwis (discharge data for Sites 11422500 and 11424000).

b. Biological data for California Lakes and Reservoirs, http://waterdata.usgs.gov/ca/nwis/qwdata.

Vander Zanden, M. J., and Rasmussen, J. B., 1999, Primary consumer $\mathrm{d}^{13} \mathrm{C}$ and $\mathrm{d}^{15} \mathrm{~N}$ and the trophic position of aquatic consumers: Ecology, v. 80, p. 1395-1404.

Wetzel, R.G., 2001, Limnology ( $3^{\text {rd }}$ ed) Academic Press, London, 1006 p.

Wood, T.M., Baptista, A.M., Kuwabara, J.S., and Flegal, A.R., 1995, Diagnostic modeling of trace metal partitioning in south San Francisco Bay: Limnology and Oceanography, v. 40, p. 345-358.

Woods, P.F., Nearman, M.J., and Barton, G.J., 1999, Quality assurance project plan for U.S. Geological Survey studies in support of Spokane River Basin RI/FS.: U.S. Environmental Protection Agency, Seattle, Washington, and U.S. Geological Survey, Boise, Idaho, 153 p. 
Word, J.Q., 1980, Classification of benthic invertebrates into infaunal trophic index feeding groups, Bascom, W., ed., Biennial Report: Southern California Coastal Research Project, Long Beach, CA, p. 103-121.

Yan, N.D., Keller, W., Scully, N.M., Lean, D.R.S., and Dillon, P.J., 1996, Increased UV-B penetration in a lake owing to drought-induced acidification: Letter to Nature, v. 381, p. 141-143. 


\section{Acknowledgments}

The authors thank M. Olson, J. DeWild, and S. Olund (USGS, Madison, WI) for mercury-speciation analyses, C. Lopez for benthic-chlorophyll analyses, and S. Hager for dissolved-nutrient analyses. Logistical and facilities support by M .Hunerlach and K. Rider is much appreciated. We are also grateful for discharge data and statistics by P. Shiffer (USGS, Sacramento, CA) and J. Erickson (Nevada Irrigation District, Colfax, CA). The California State Water Resources Control Board (Joint-funding Agreement 00-218-250-0) and in particular R. Humphreys are gratefully acknowledged for support of this work, as is the U.S. Geological Survey Toxic Substances Hydrology Program for long-term support of this area of research.

Product names are provided for identification purposes only and do not constitute endorsement by the U.S. Geological Survey. 


\section{Appendix 1: Comments on the Report Structure}

A major objective of this electronic document is to provide a structure that is easily accessible to a wide range of interest groups. Therefore, pathways within this document have been constructed to be both logical and intuitive. In addition to hyperlinks within the document to supporting figures and tables, links in Appendices 2 and 3 provide a quick way to directly review and examine all figures and tables.

Although hard copies of this report are available on request, the advantages of the electronic version relative to the hard copy are substantial in many respects, but particularly in the rapid access of information at multiple levels of detail.

Your comments about how this type of Web-based product may be improved to better serve readers are most welcome and may be directed to the major author (kuwabara@usgs.gov) so that they may be compiled for future revisions and reports. 


\section{Appendix 2: List of Figures}

Fig. 1 - Site map of the study area

Fig. $2-$ Photos of the coring operation

Fig. 3 - Hydrological conditions during the study period

Fig. $4-$ Temperature and dissolved-oxygen trends in the water-column

Fig. 5 - Comparison of the ranges for benthic indices

Fig. 6 - Methyl-Hg and total-Hg flux comparisons

Fig. 7 - Upstream remediation efforts potentially affect lake gradients

Fig. 8 - Conceptual model of solute transport through a reservoir

Fig. 9 - Processes regulating benthic flux of solutes

Fig. $10-$ Water-column chlorophyll and pheophytin pigment

Fig. 11 - Water-column carbon and nitrogen isotopes and elemental concentrations

Fig. 12 - Water-column total- and methyl-mercury

Fig. $13-$ Water-column trace-metal concentrations

Fig. $14-$ Benthic response to upstream remediation (zinc)

Fig. 15 - Photo of macroinvertebrate taxonomy methods

Fig. 16 - Photo of benthic-chlorophyll analyses

Fig. 17 - Photo of dissolved-oxygen analyses

Fig. $18-$ Photo of dissolved-mercury analyses

Fig. 19 - Photo of dissolved-metal analyses

Fig. 20 - Photo of dissolved-nutrient analyses

Fig. 21 - Photo of dissolved organic-carbon (DOC) analyses

Fig. $22-$ Photo of dissolved-sulfide analyses 


\section{Appendix 3: List of Tables}

\begin{tabular}{|c|c|}
\hline Table 1 & - Surficial-sediment porosities \\
\hline Table 2 & - Benthic-invertebrate taxonomy \\
\hline Table 3 & - Benthic-chlorophyll analyses \\
\hline Table 4 & - Water-column concentrations for mercury species in Camp Far West Reservoir. \\
\hline$\underline{\text { Table } 5}$ & - Dissolved-mercury fluxes \\
\hline$\underline{\text { Table } 6}$ & - Dissolved-nutrient fluxes and water-column concentrations \\
\hline Table 7 & - Dissolved-sulfide fluxes \\
\hline Table 8 & - Dissolved organic carbon (DOC) fluxes and water-column concentrations \\
\hline$\underline{\text { Table } 9}$ & - Photosynthetic pigments and stable isotopes in suspended particles \\
\hline Table 10 & - Dissolved oxygen consumption \\
\hline Table 11 & - Dissolved-trace-metal water-column concentrations \\
\hline Table 12 & - Implications for upstream management \\
\hline
\end{tabular}


Fig. 1. Coring Sites at Camp Far West Reservoir

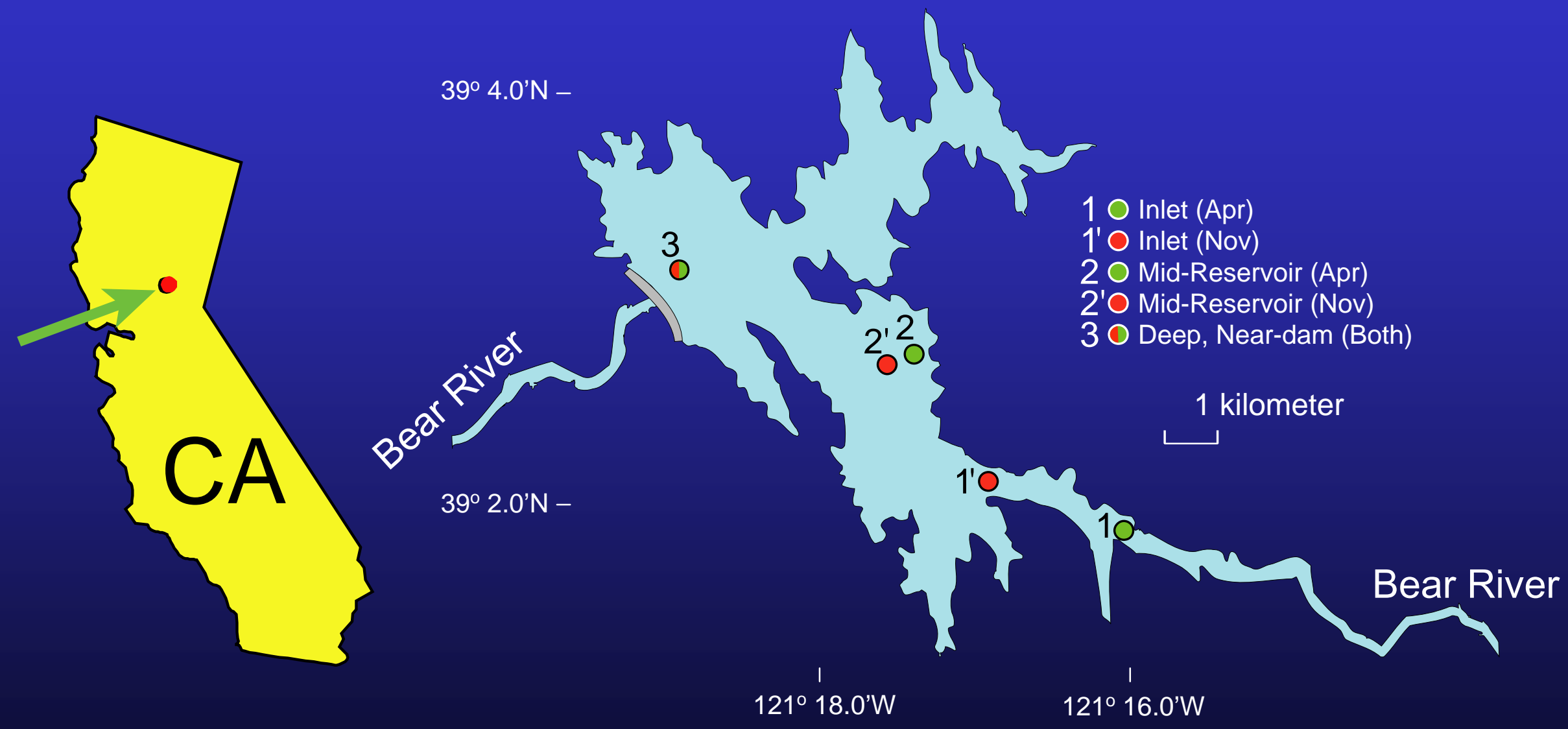

\section{\#USGS}


Fig. 2. Coring Operation

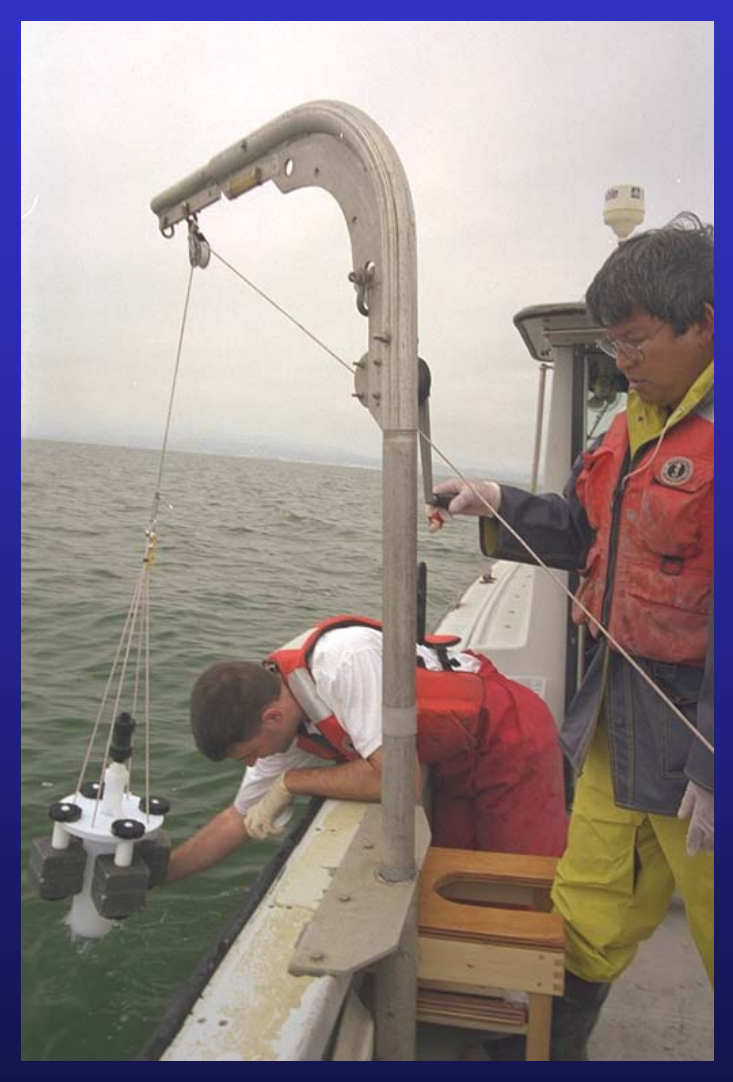

Release

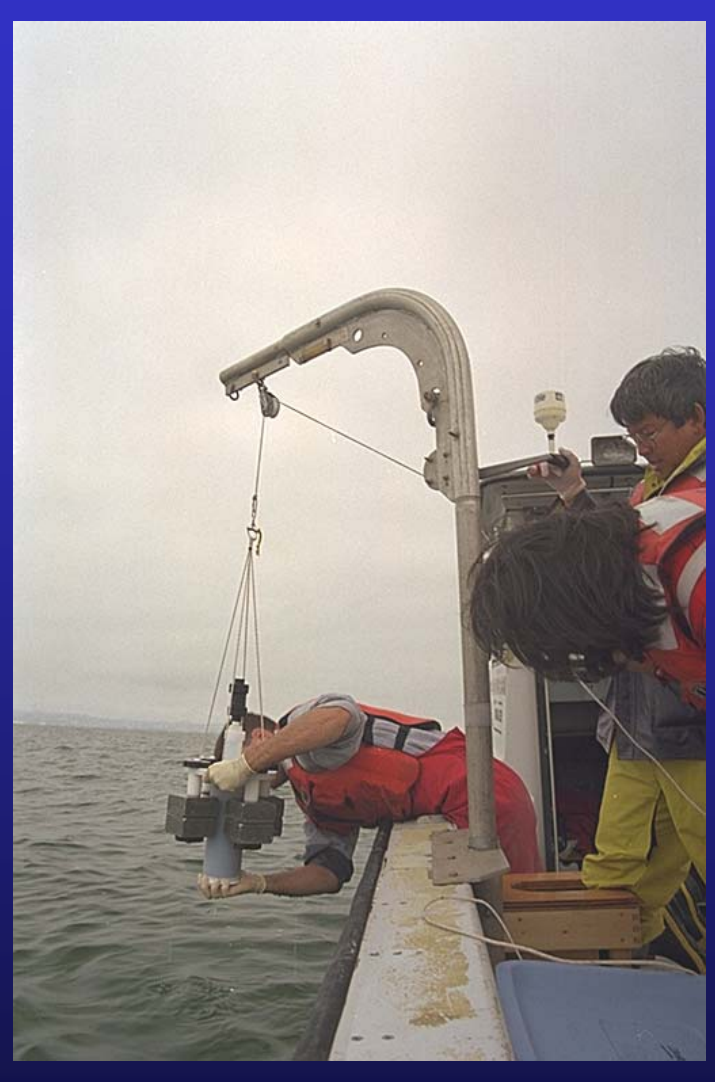

Retrieval

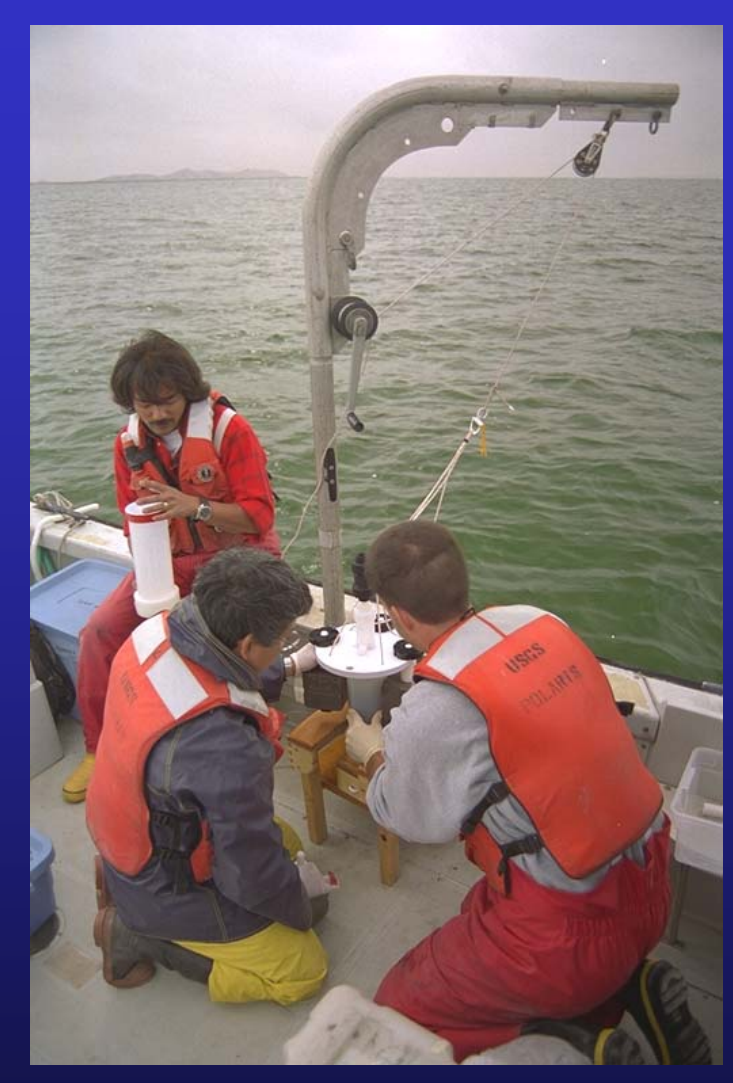

Removal 
Fig. 3. Hydrologic Conditions

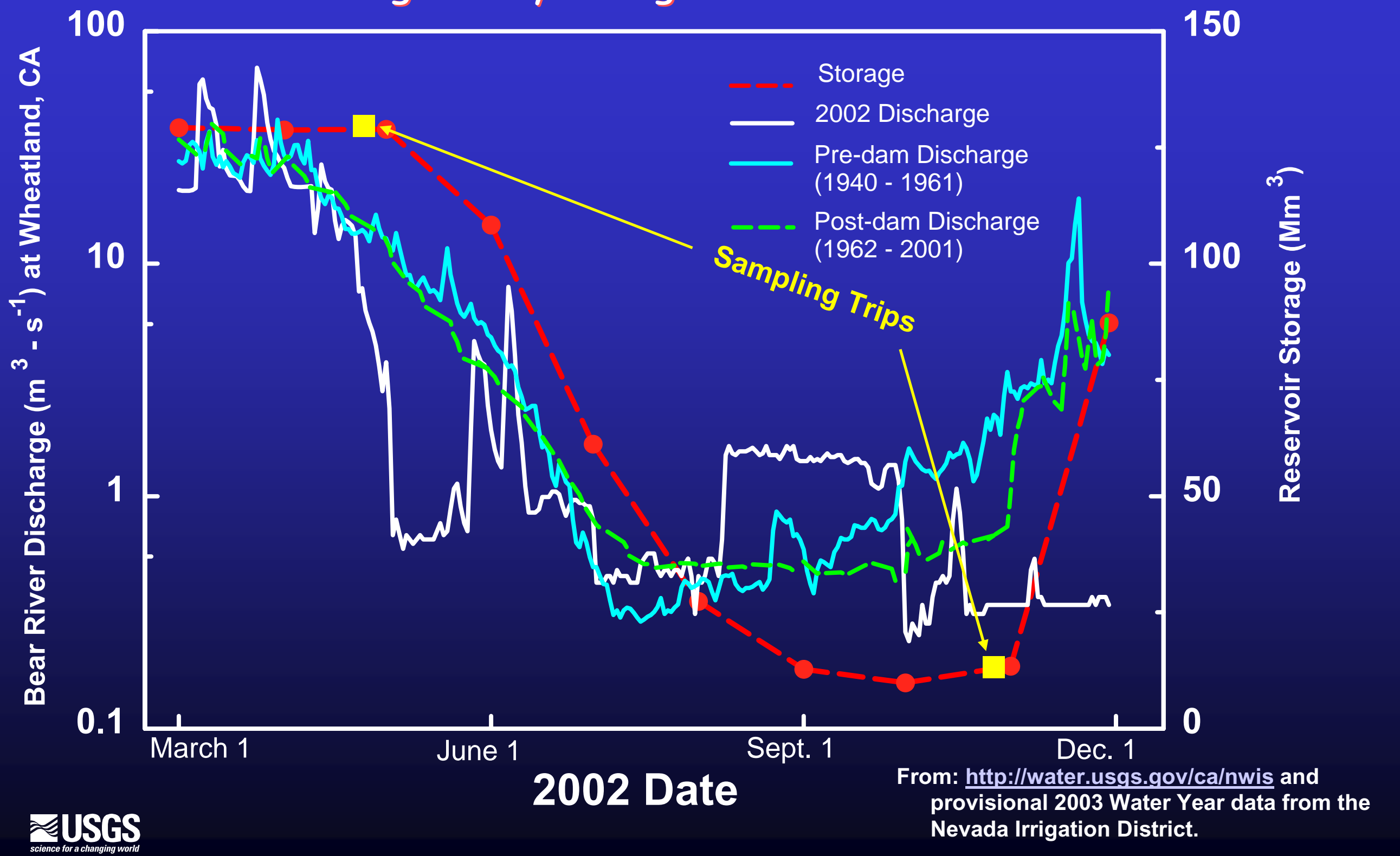


Fig. 4. Temporal Shifts in Water-column Conditions at the Near-dam Site

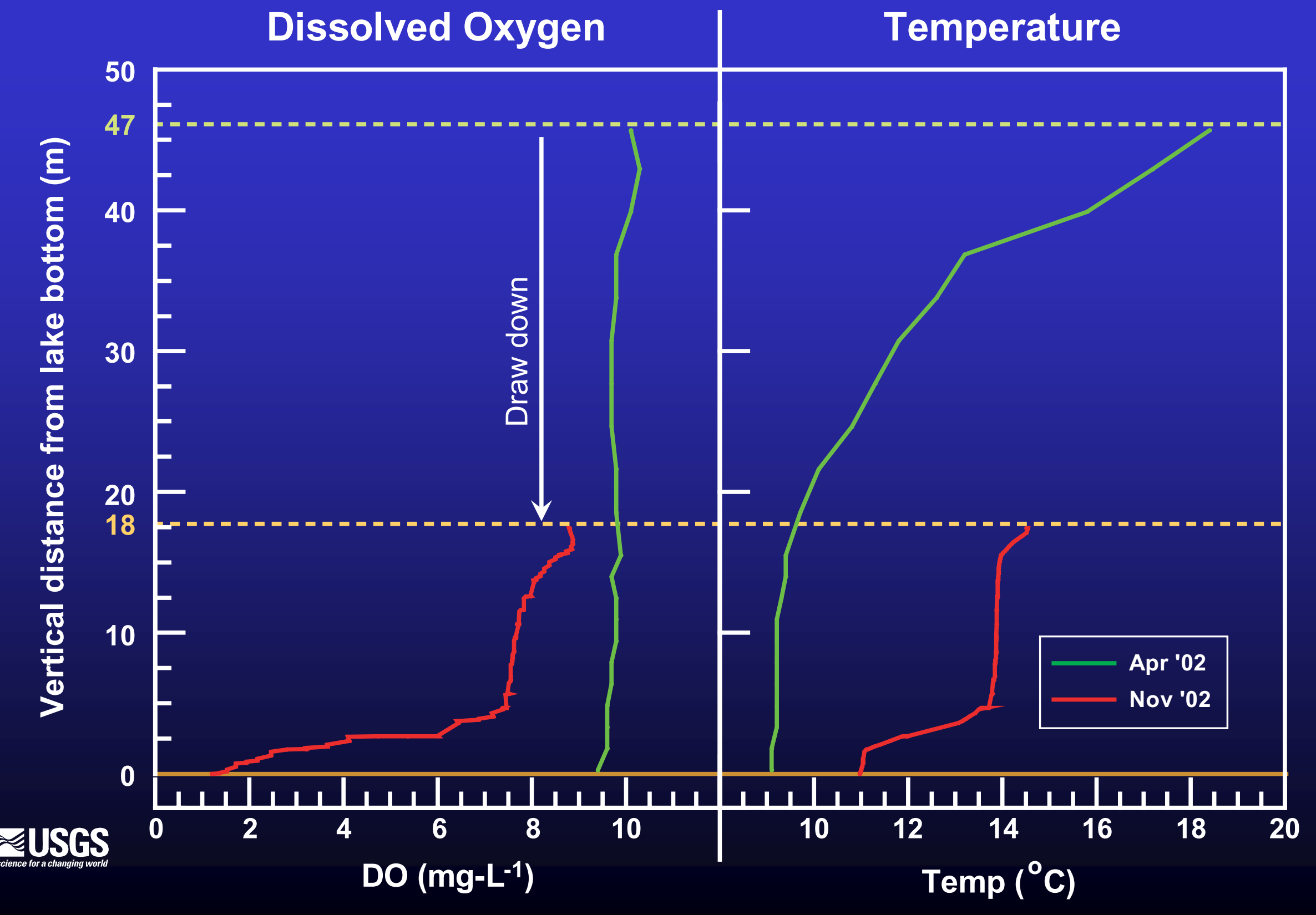




\section{Fig. 5. Benthic Community Characterization}
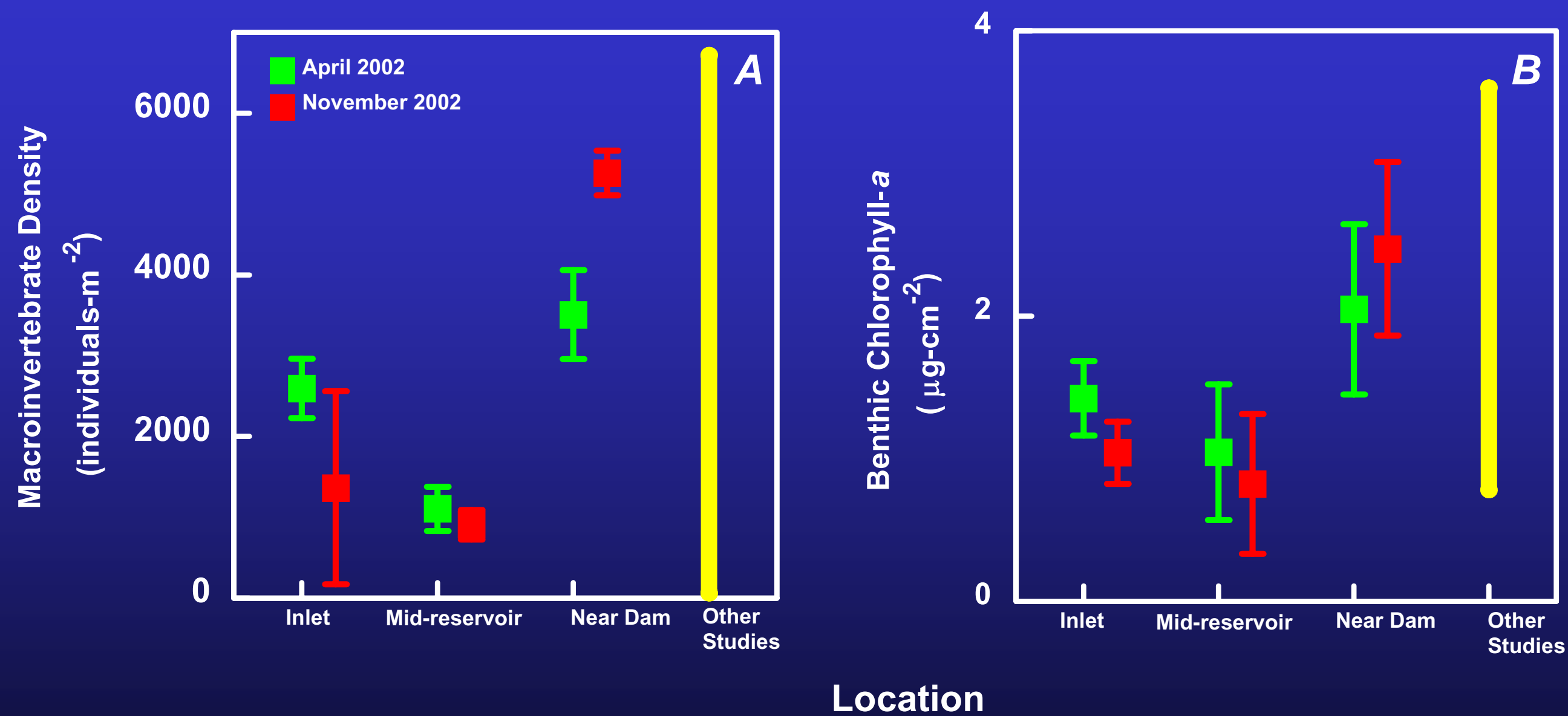
Fig. 6. Hg-flux

Comparisons between Mining-affected Reservoirs

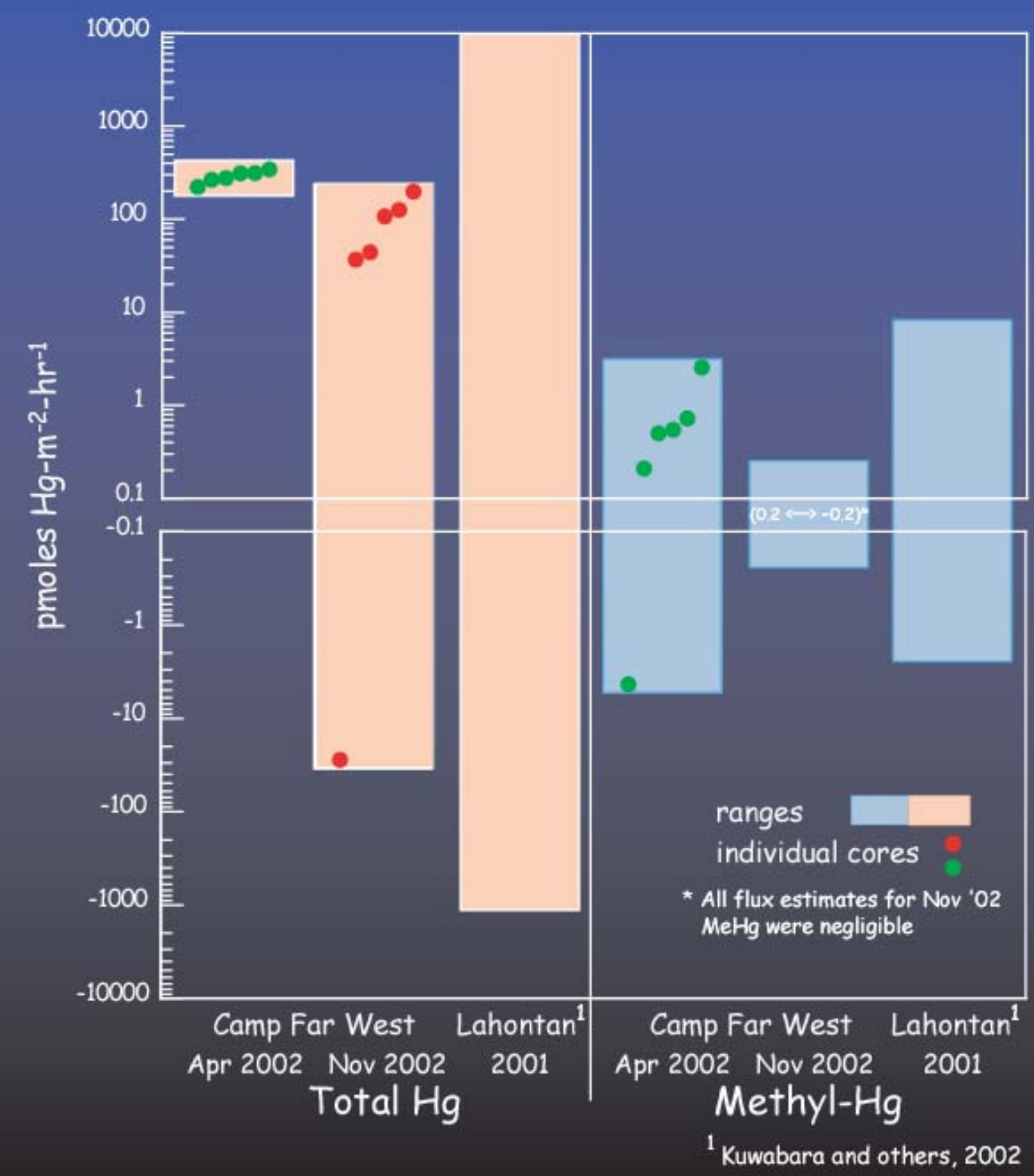




\section{Fig. 7. Remediation efforts in the river can affect concentration gradients in the reservoir}

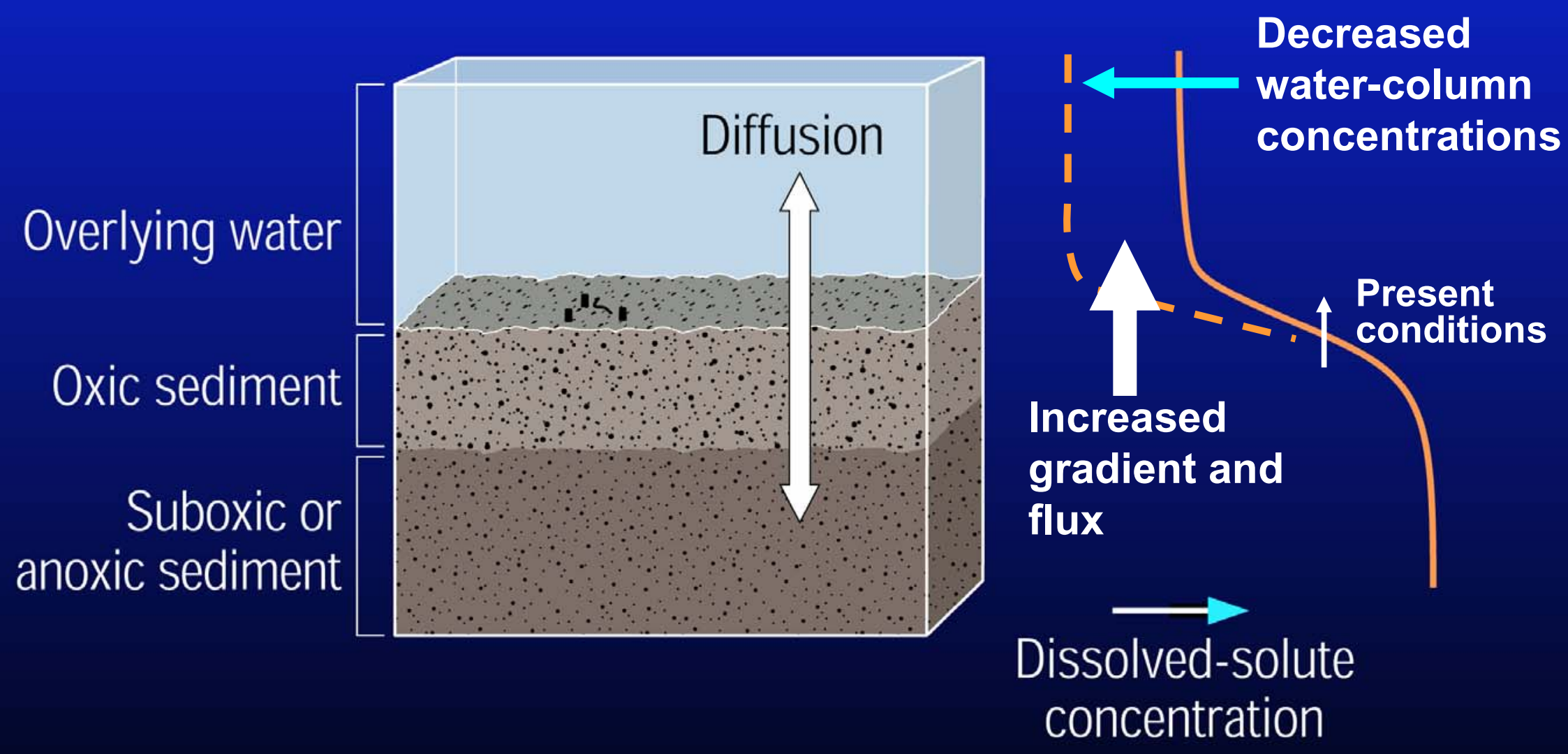




\section{Fig. 8. Conceptual Model of Solute Transport}

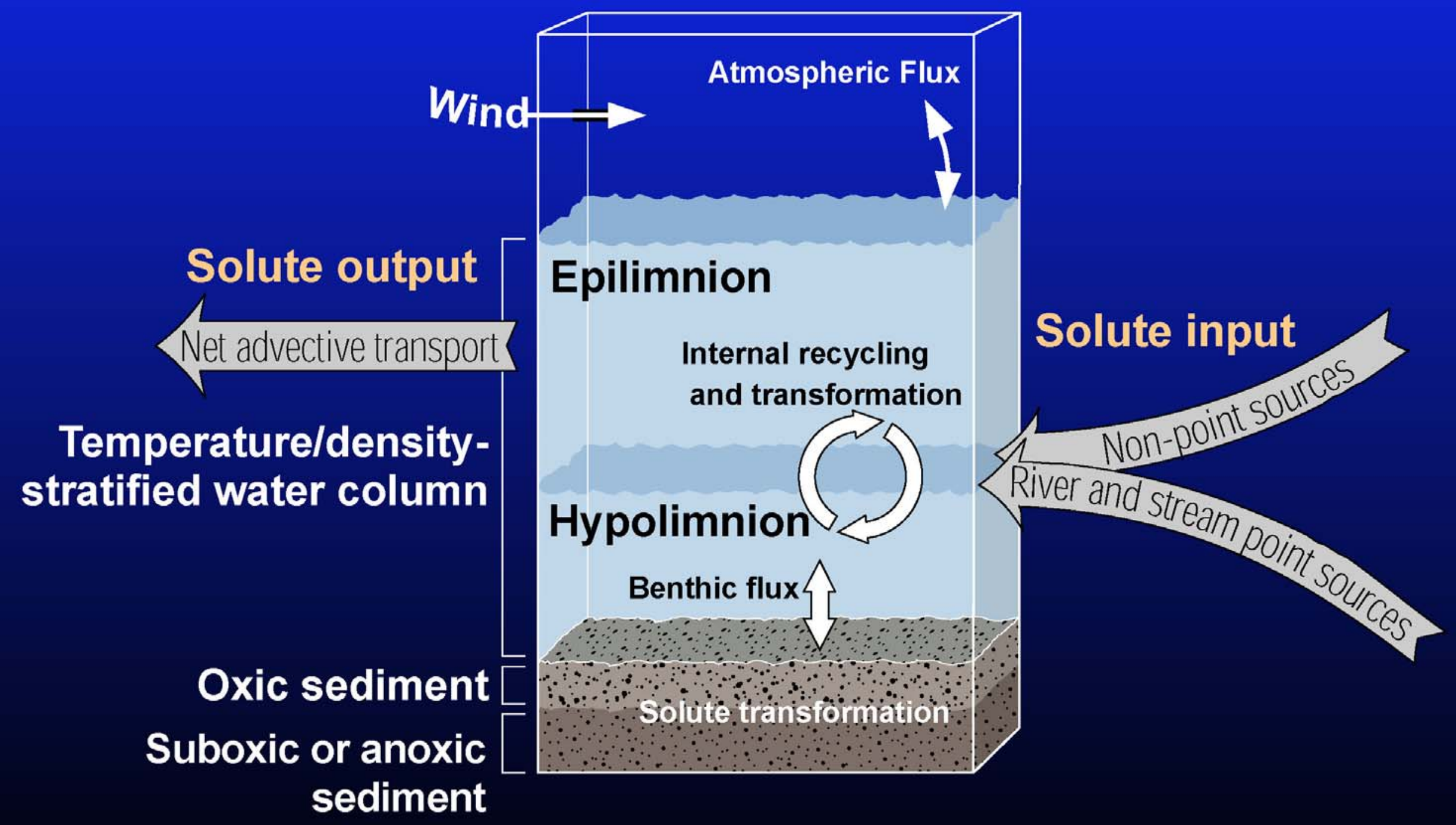


Fig. 9. Processes Regulating Benthic Flux

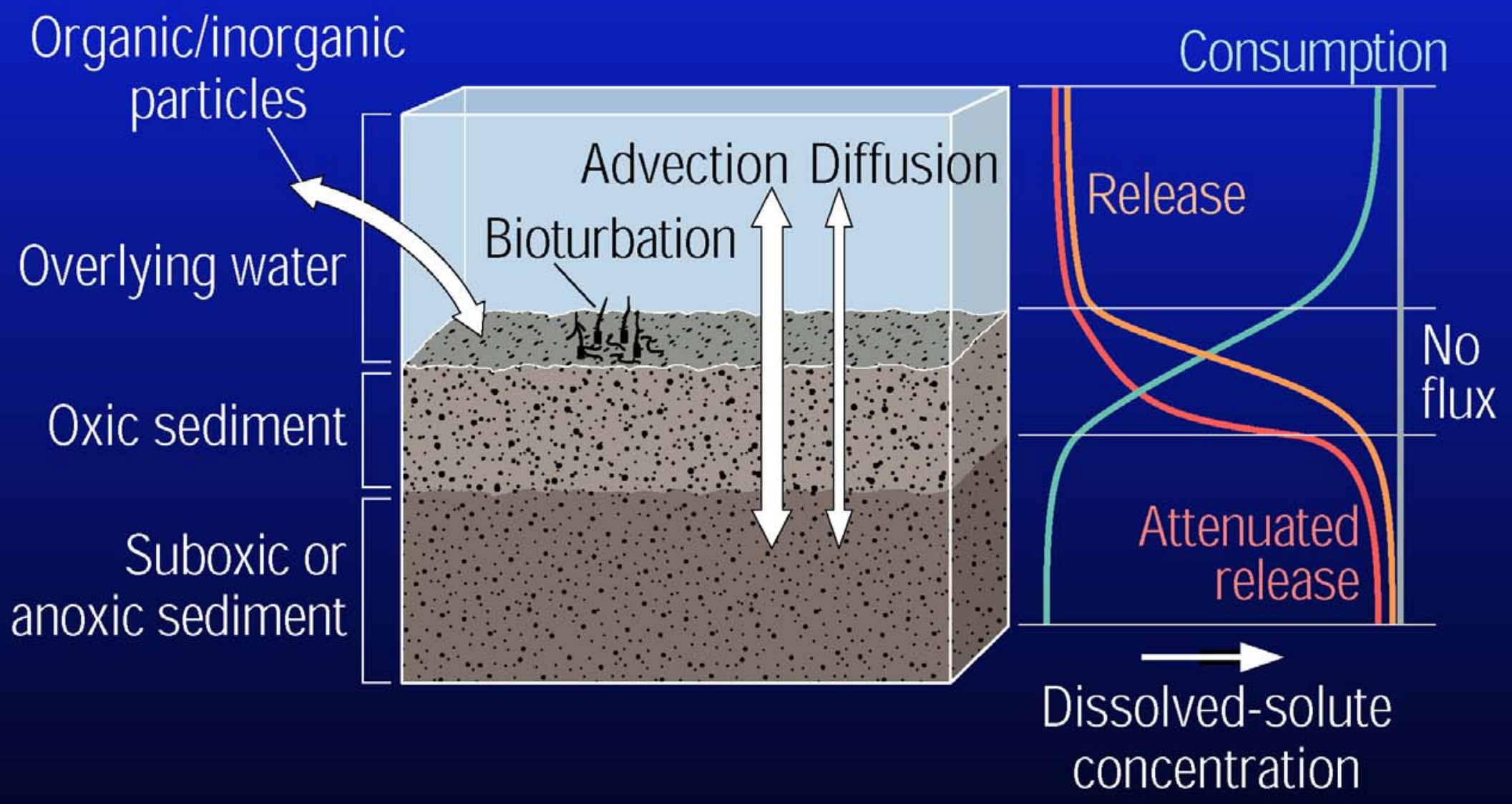


Figure 10. Seasonal dynamics of chlorophyll and pheophytin pigments in Camp Far West Reservoir.

A. Chlorophyll-a concentration $\left(\mu g-L^{-1}\right)$.

B. Pheophytin concentration $\left(\mu g^{-L^{-1}}\right)$.

C. Proportion of chlorophyll to pheophytin pigment.

Values are means \pm deviation $(n=2)$.
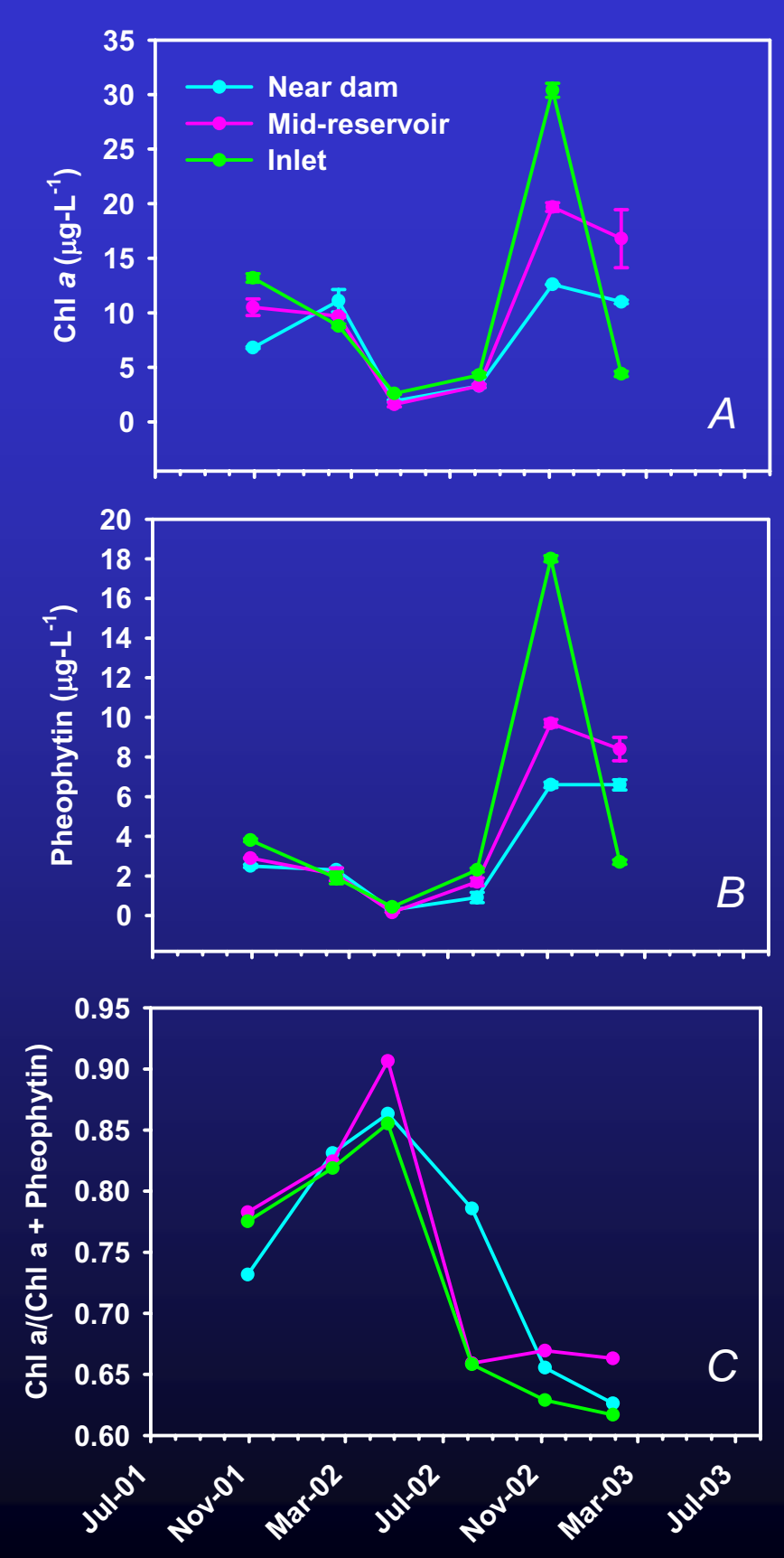
Figure 11. Seasonal trends in the elemental and isotopic composition of suspended particulate material (SPM) in Camp Far West Reservoir.

A. $\delta^{13} C$ of SPM.

B. $\delta^{15} \mathrm{~N}$ of SPM.

C. Molar ratio of carbon to nitrogen in SPM relative to the molar Redfield ratio (6.7).

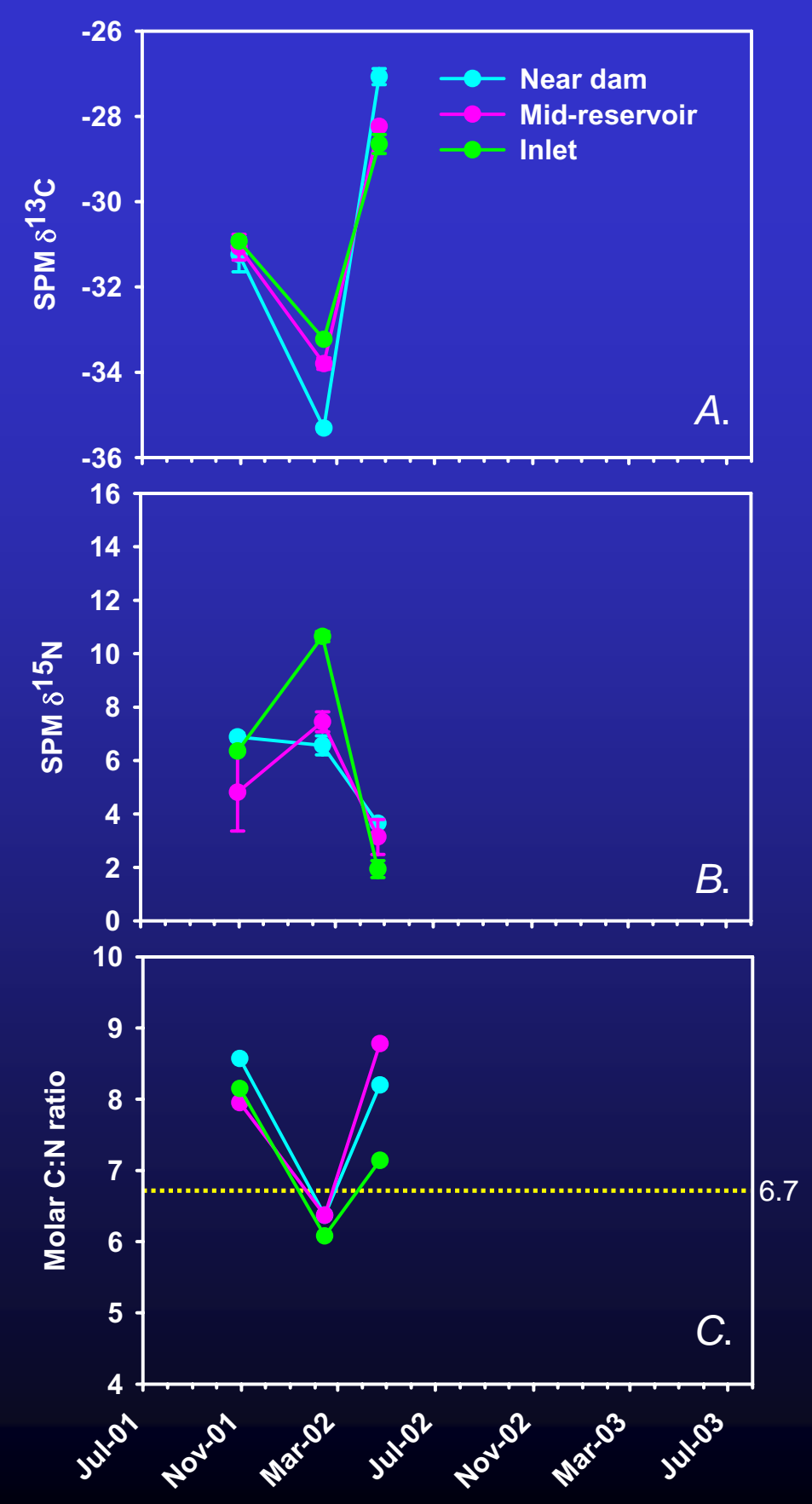


Fig. 12. Water-column concentrations of mercury species

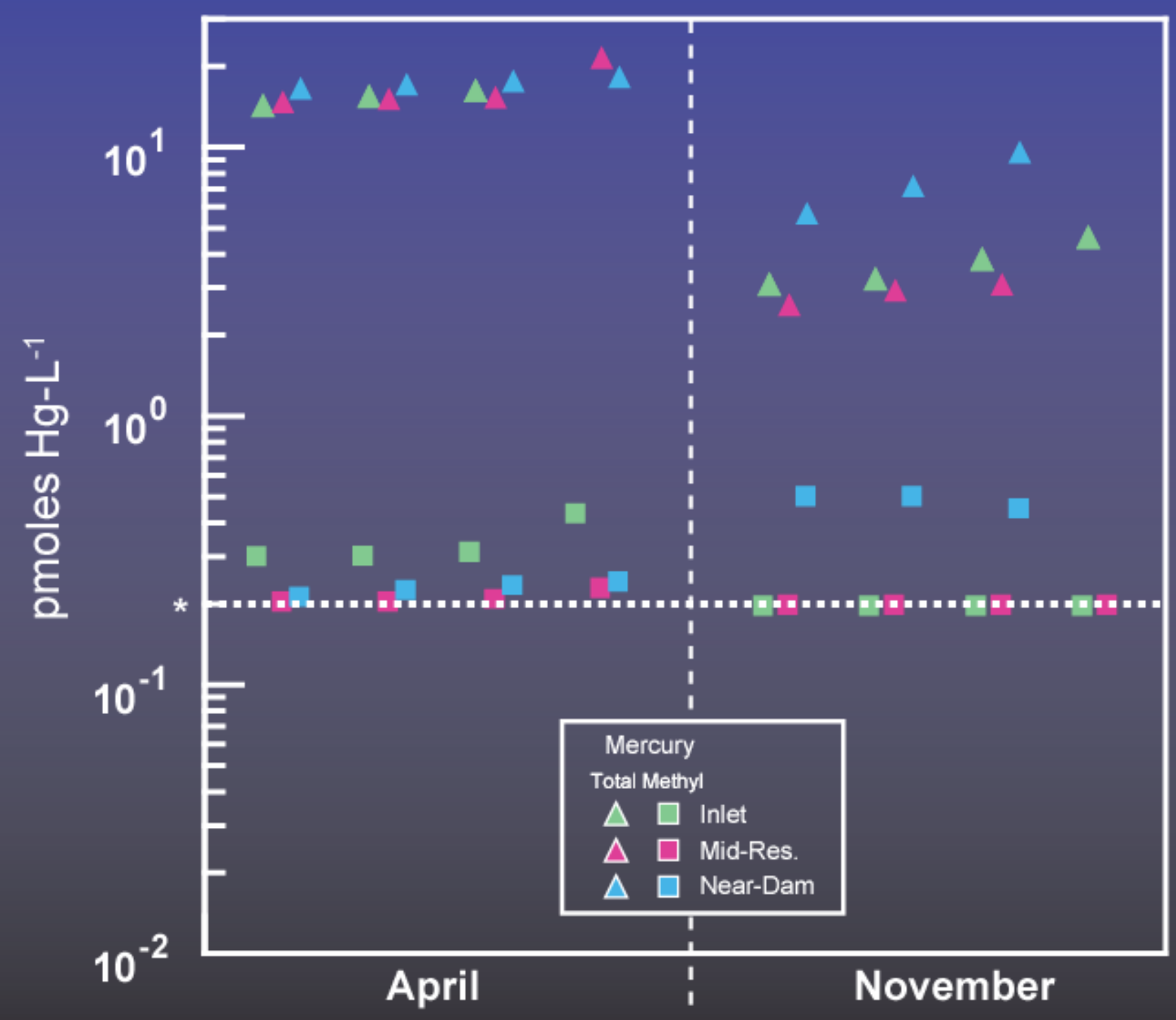


Fig. 13. Water-column trace-metal concentrations at Deep, near-dam site

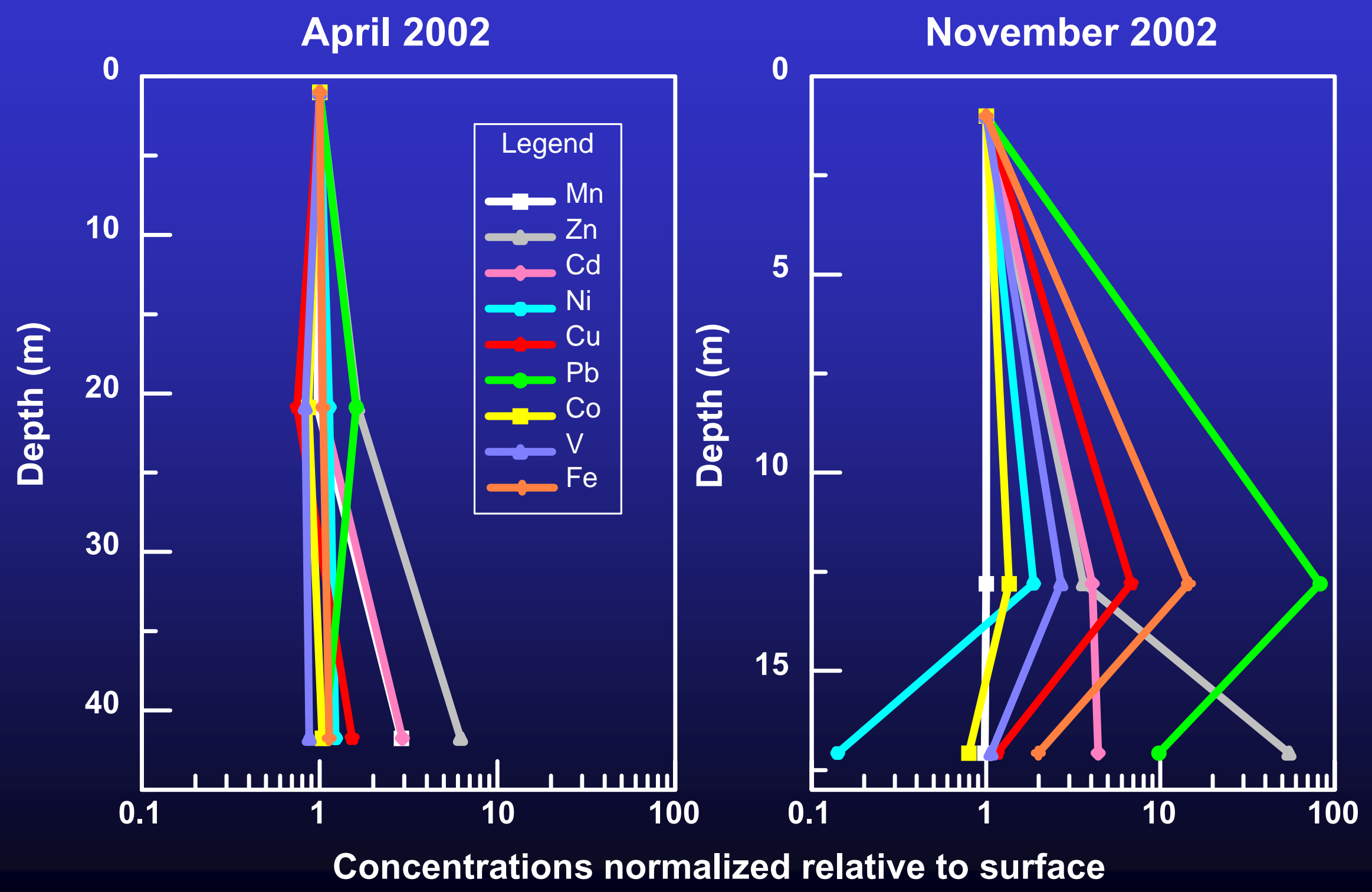




\section{Fig. 14. Benthic response to upstream remediation or load reductions (An extended example for zinc)*}

* Data points indicate calculated changes in diffusion-controlled benthic flux resulting from a hypothetical $50 \%$ decrease in dissolved-zinc concentration in the reservoir.

Curves represent changes in benthic flux for lake environments that reflect contrasting pore-water quality (modified from Kuwabara and others, 2003).

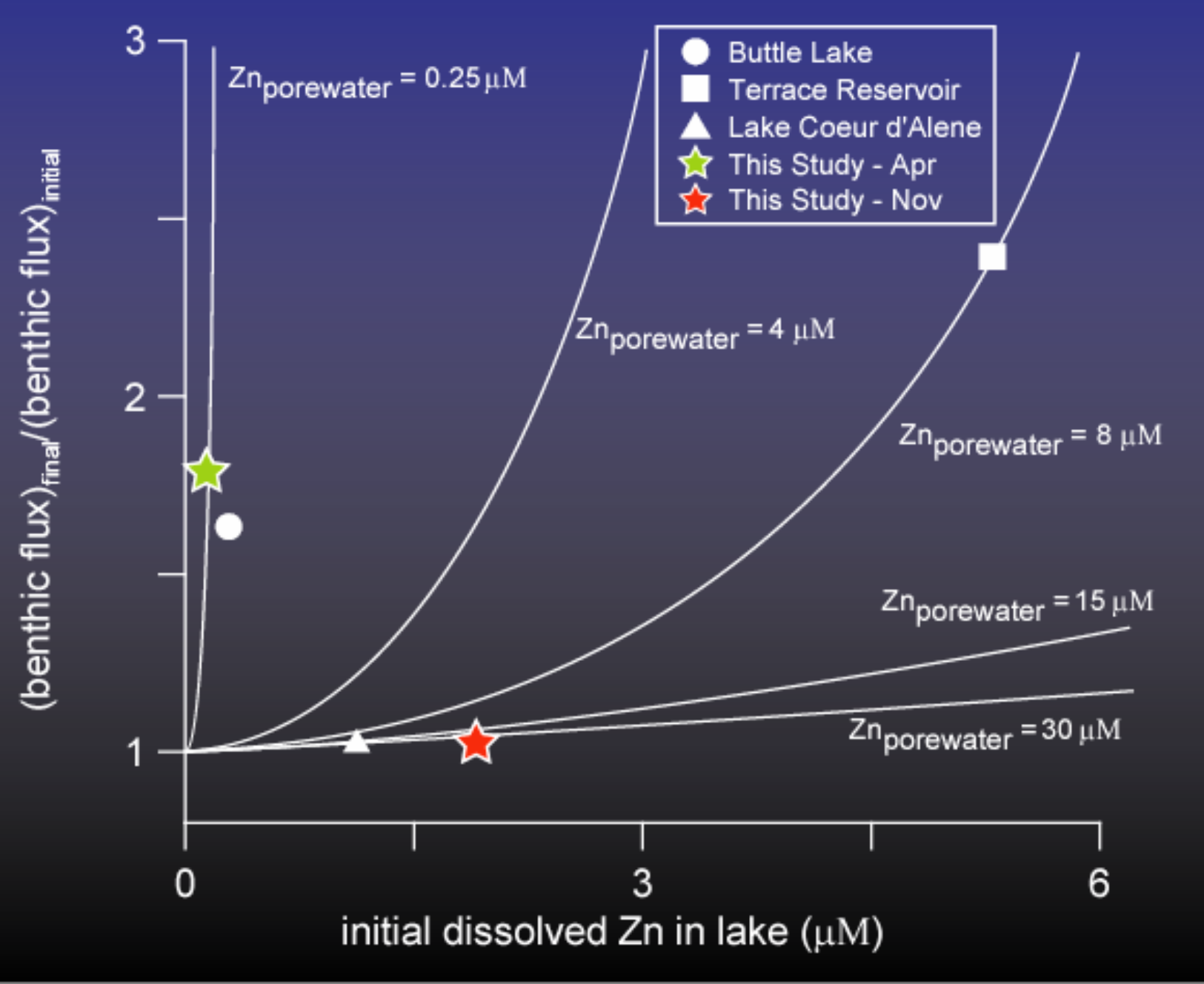


Fig. 15. Benthic Macroinvertebrate Taxonomy

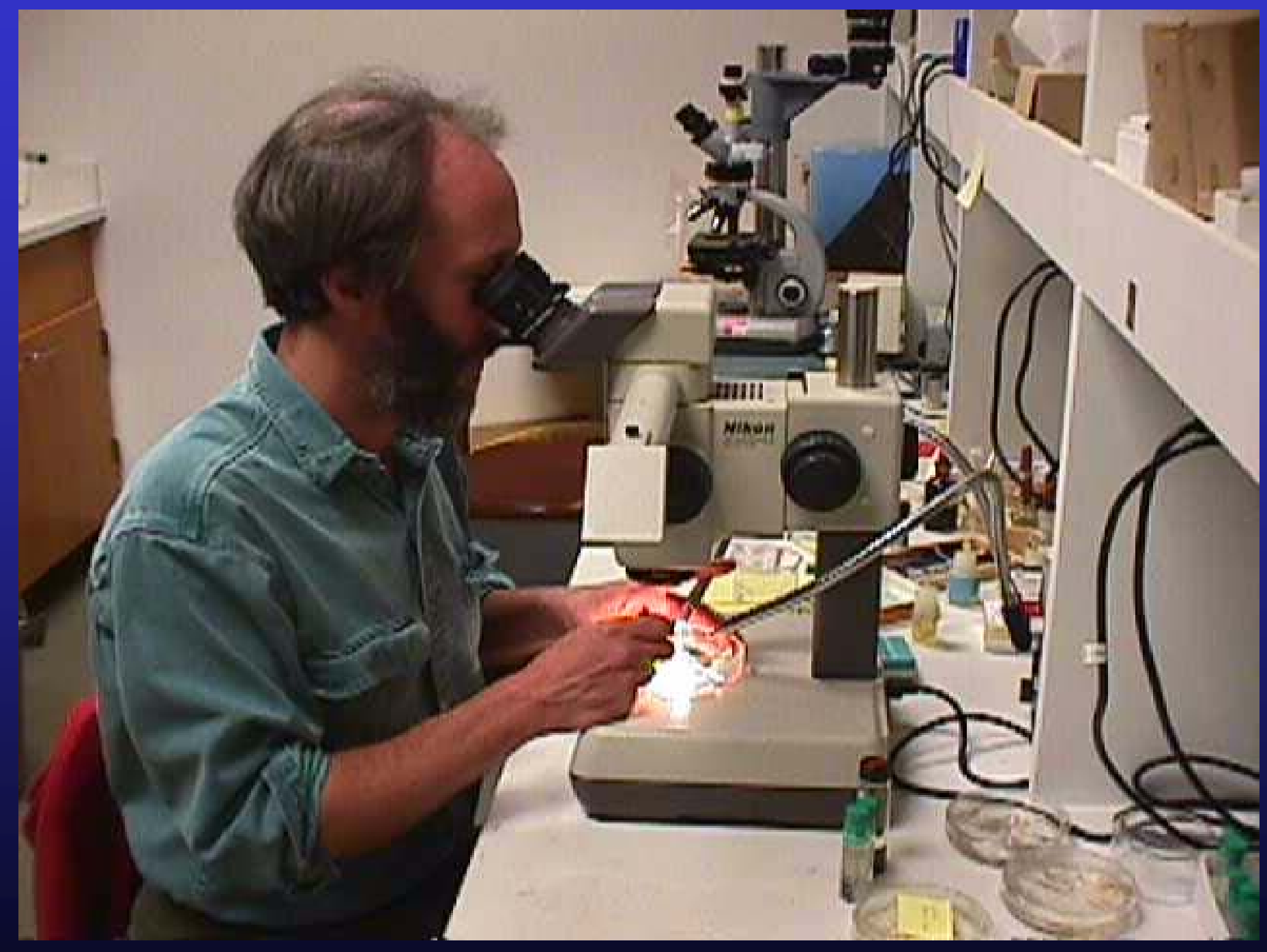


Fig. 16. Benthic Chlorophyll Analyses

\section{ZUSES}

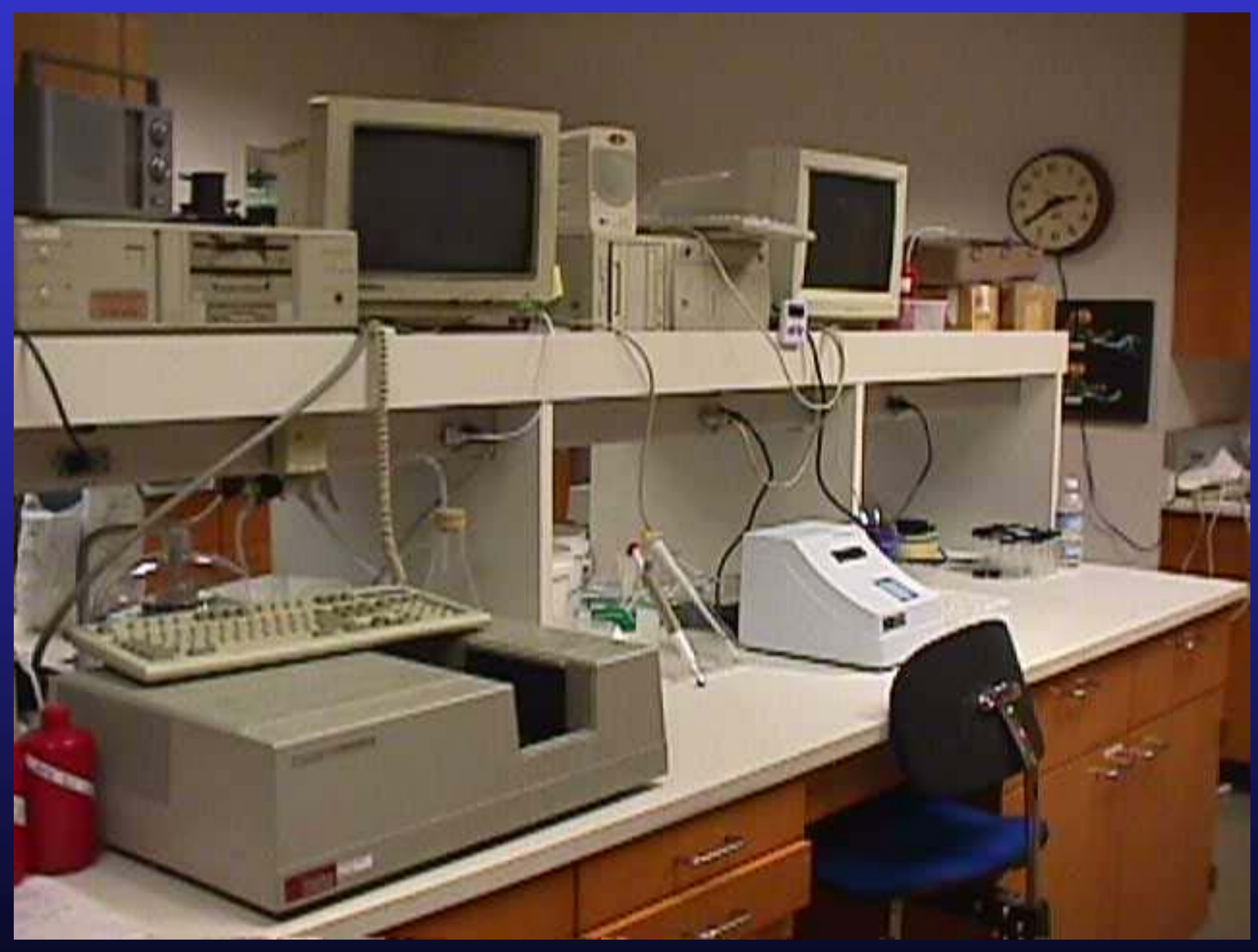

Modified from Kuwabara and others (2000) 
Fig. 17. Dissolved-oxygen Analyses by Micro-Winkler Titration

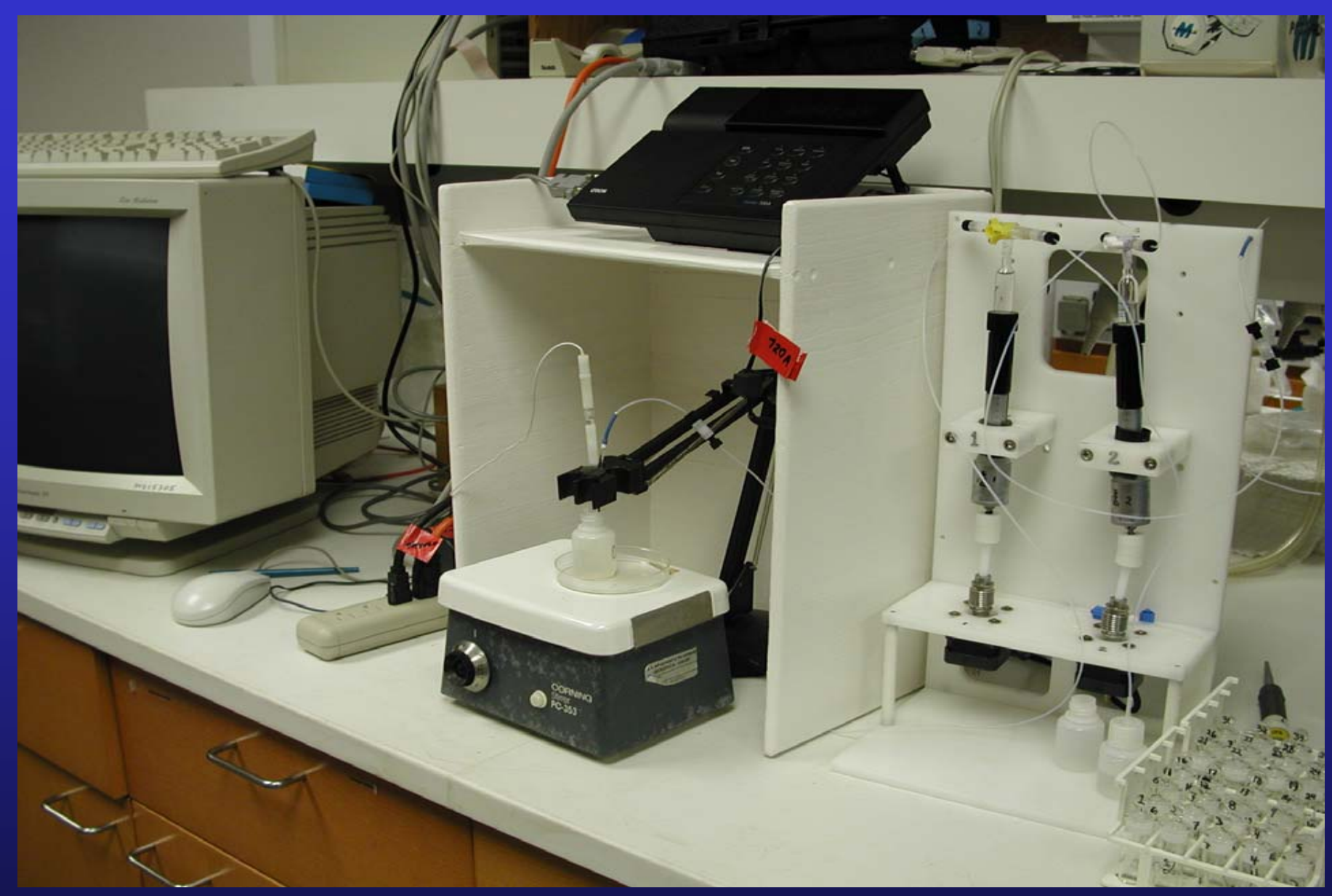

Figures of merit for dissolved oxygen

$$
\text { Detection limit }
$$


Fig. 18. Cold-vapor Atomic Fluorescence Spectroscopy (CVAFS)

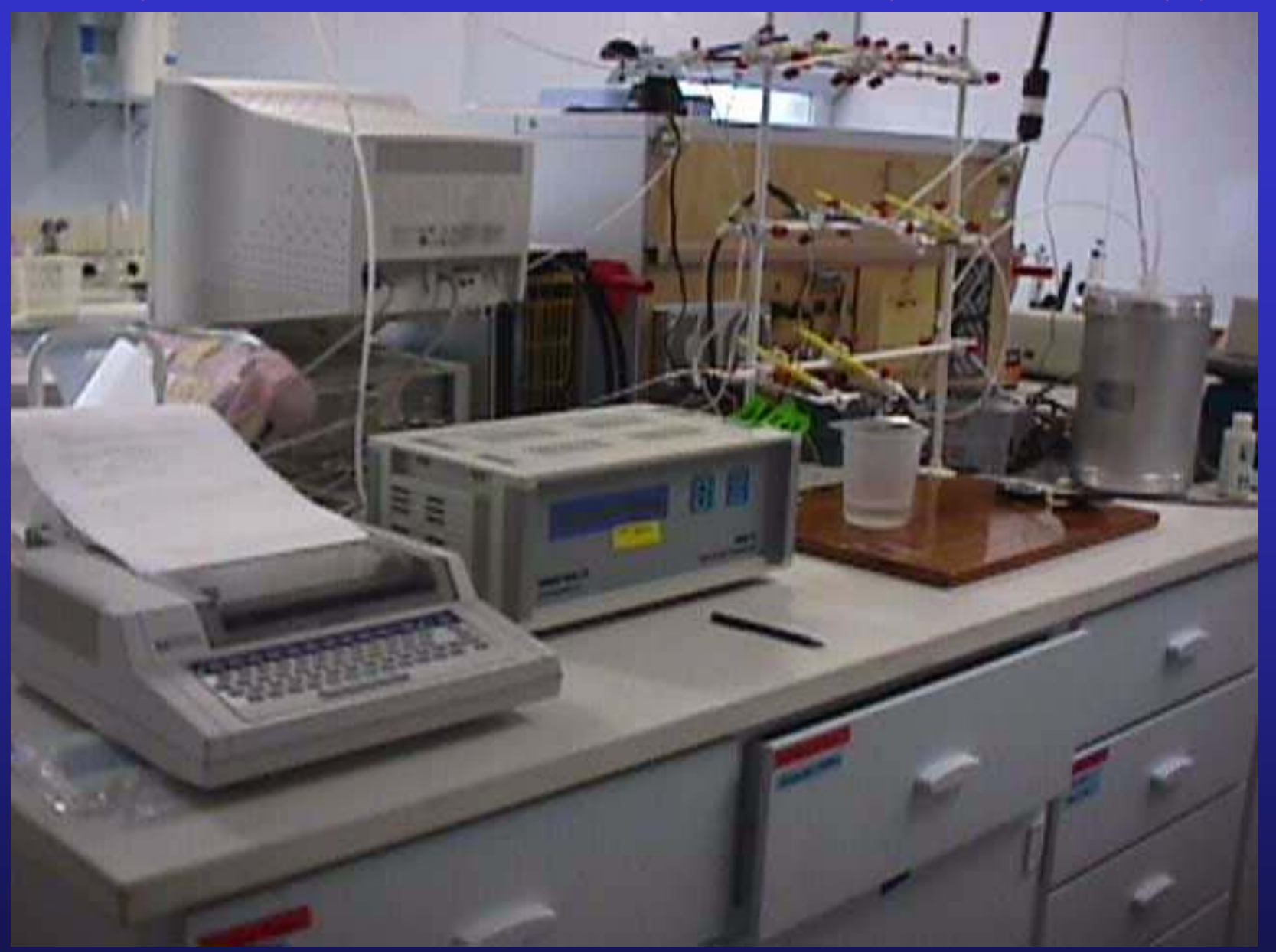

Figures of merit for mercury analysis

Detection limit 
Fig. 19. Dissolved Trace-Metal Analyses by Inductively Coupled Plasma Mass Spectrometry (ICP-MS)

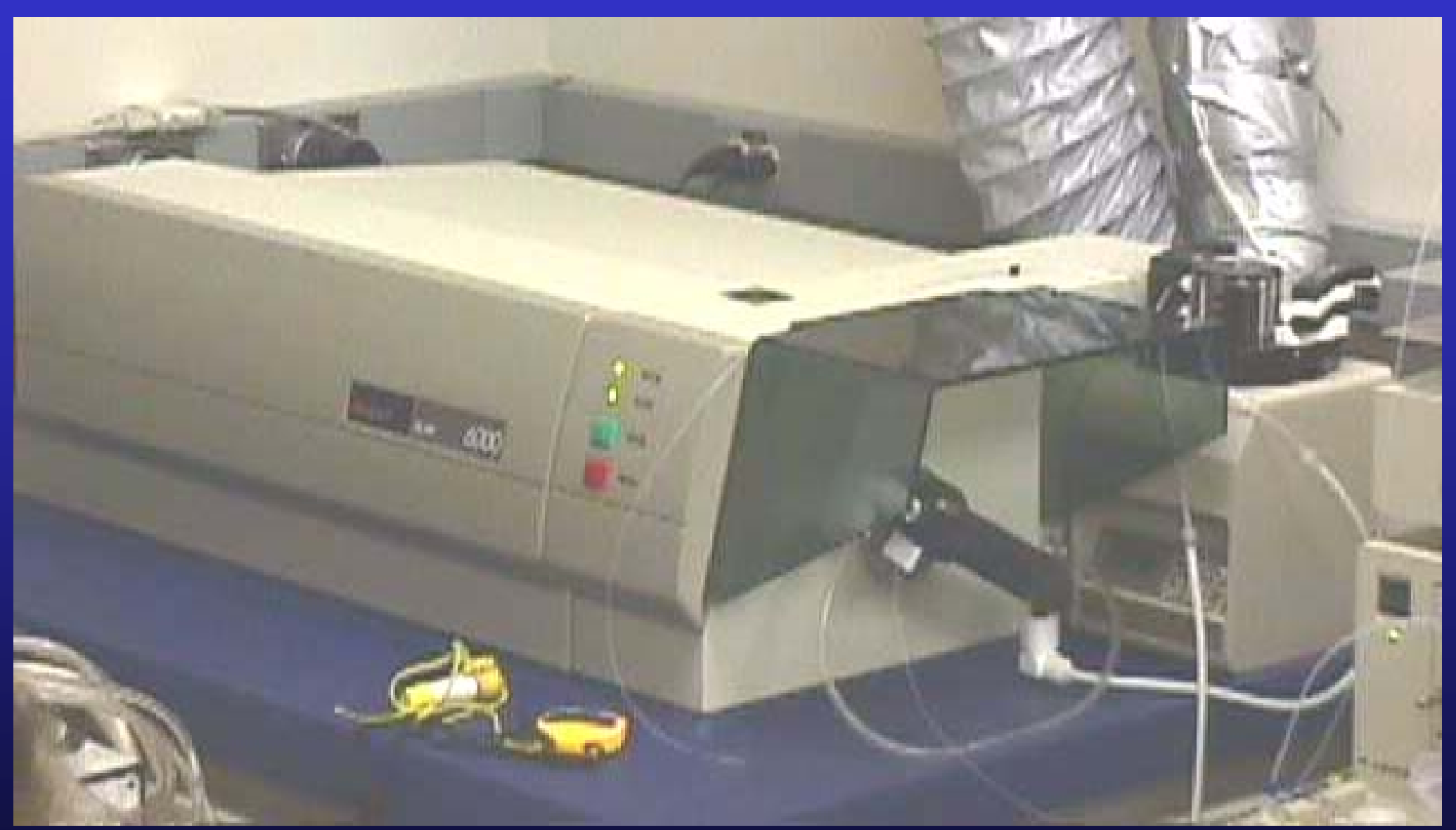

Figures of merit for metal analyses

Detection limit

Zn $0.1 \mu \mathrm{g} / \mathrm{L}$

$\mathrm{Cu} 0.01 \mu \mathrm{g} / \mathrm{L}$

Cd $0.01 \mu \mathrm{g} / \mathrm{L}$

$\mathrm{V} 0.01 \mu \mathrm{g} / \mathrm{L}$

Ni $0.05 \mu \mathrm{g} / \mathrm{L}$

$\mathrm{Mn} 0.1 \mu \mathrm{g} / \mathrm{L}$

$\mathrm{Pb} 0.01 \mu \mathrm{g} / \mathrm{L}$

Co $0.01 \mu \mathrm{g} / \mathrm{L}$

Fe $5 \mu \mathrm{g} / \mathrm{L}$ 
Fig. 20. Dissolved Nutrient Analyses by Automated Spectrophotometry

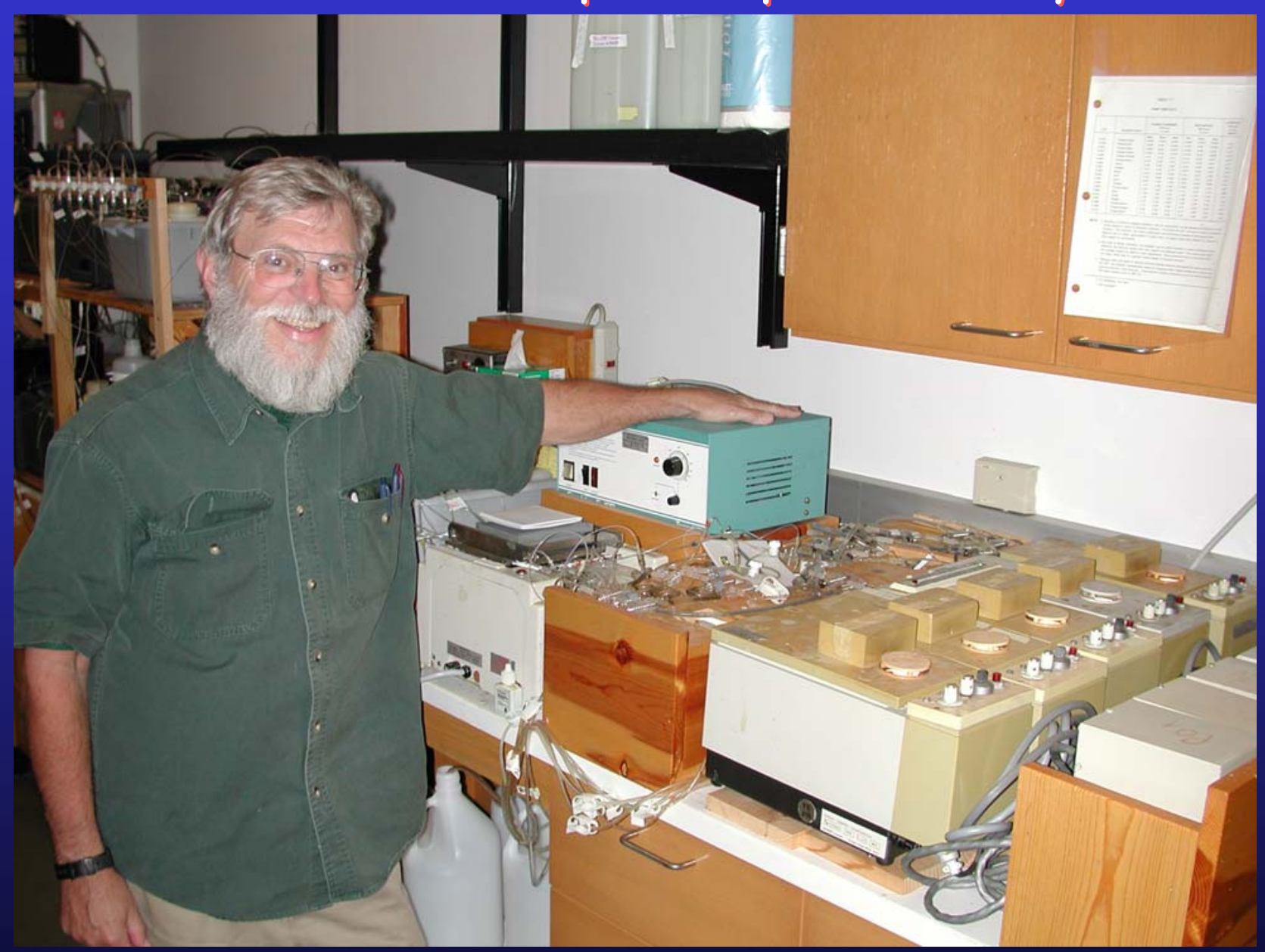

Figures of merit for nutrient analysis 
Fig. 21. Dissolved Organic Carbon (DOC) Analyses by High-Temperature Non-Catalytic Oxidation

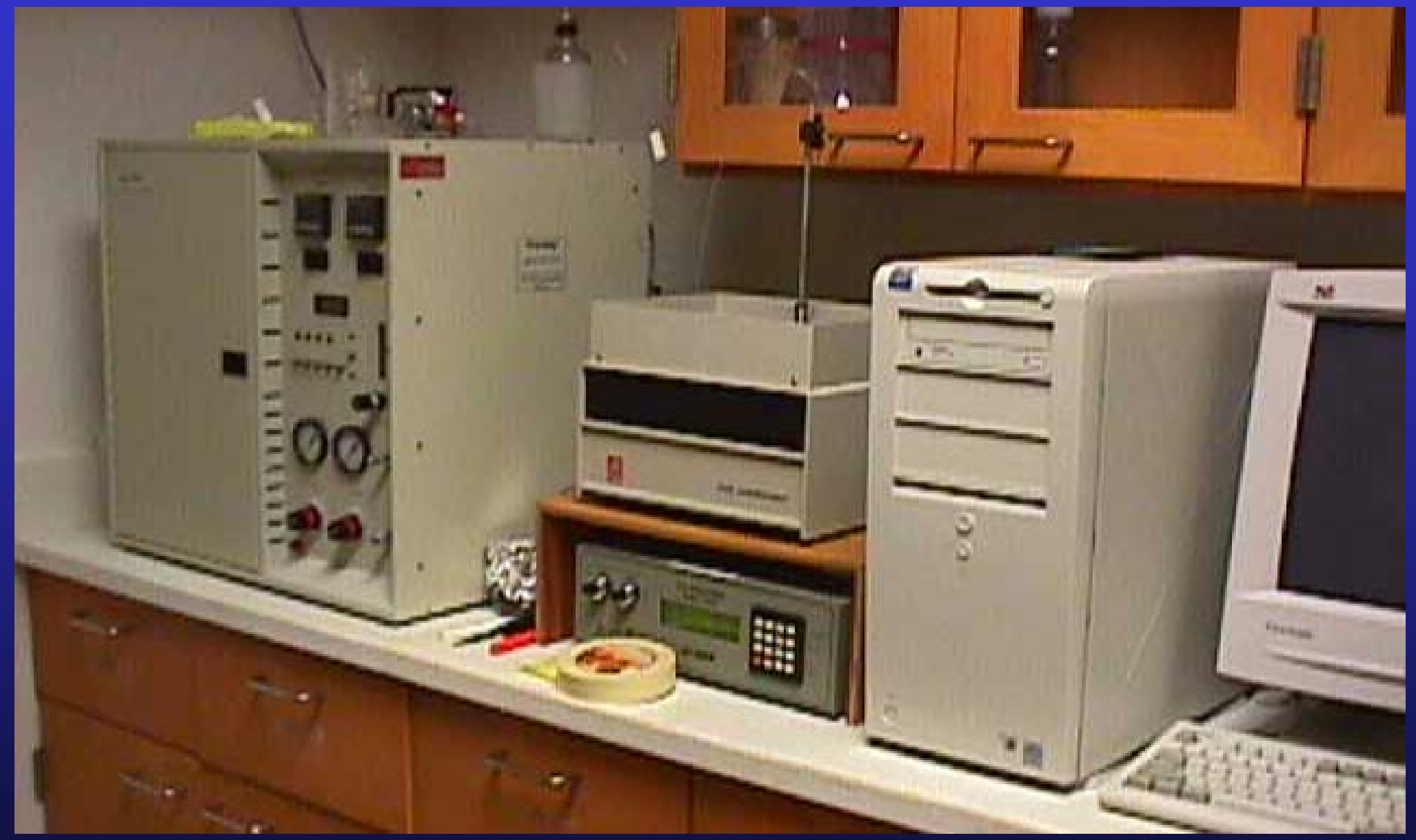

Figures of merit for DOC analysis 
Fig. 22. Dissolved-sulfide Analyses by Square-wave Voltammetry

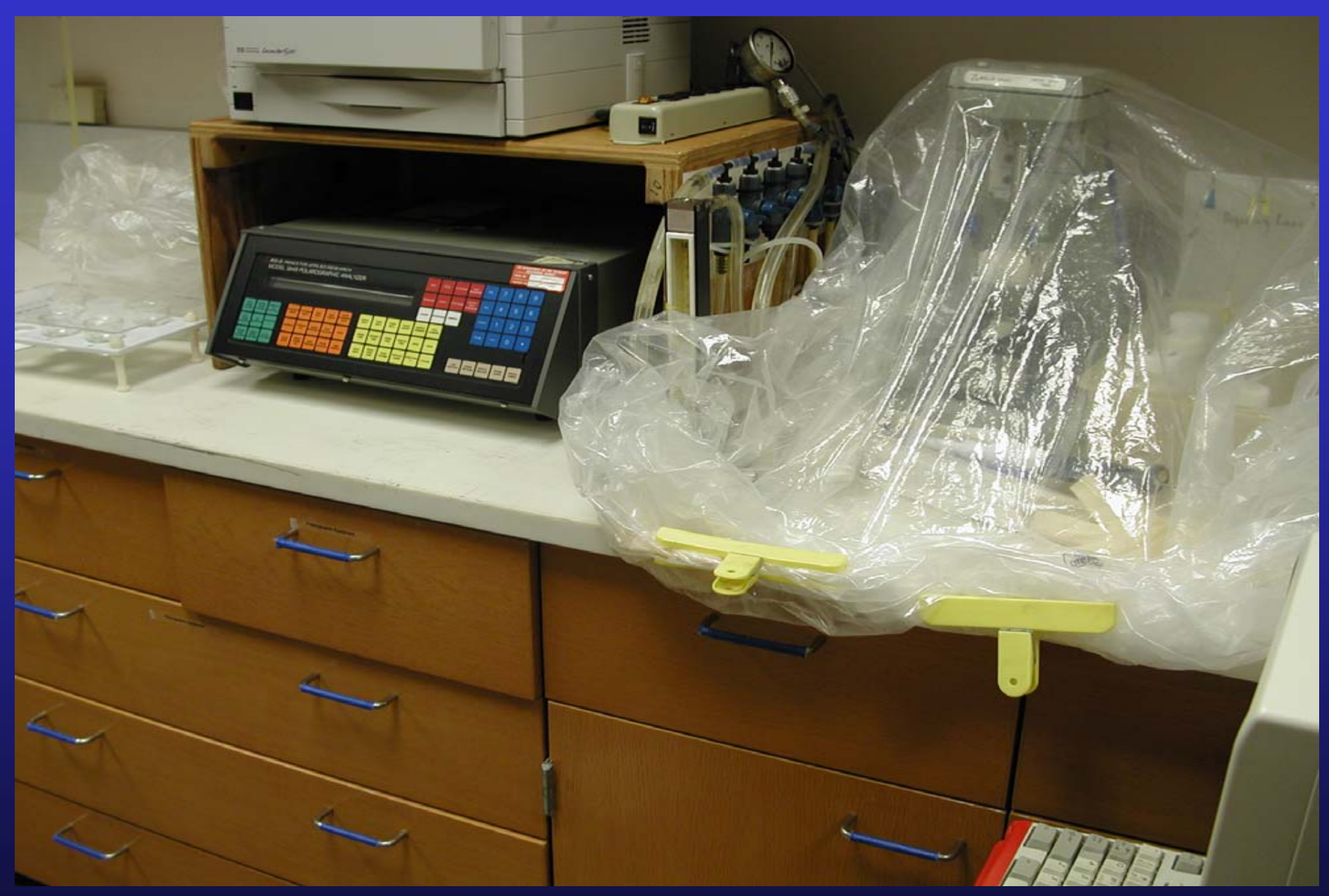

Figures of merit for sulfide analysis

Detection limit 
Table 1. Surficial sediment porosities for Camp Far West Reservoir, 2002

April 24, 2002

\begin{tabular}{|lrr|}
\hline & \multicolumn{2}{c|}{ Core } \\
Site & Number & Porosity \\
\hline Inlet & 2 & 0.84 \\
Inlet & 4 & 0.87 \\
Mid-reservoir & 5 & 0.94 \\
Mid-reservoir & 6 & 0.88 \\
Near dam & 10 & 0.98 \\
Near dam & 11 & 0.96 \\
\hline
\end{tabular}

November 4, 2002

\begin{tabular}{|lrr|}
\hline Site & Core & \\
Number & Porosity \\
\hline Inlet & 2 & 0.85 \\
Inlet & 3 & 0.90 \\
Mid-reservoir & 6 & 0.65 \\
Mid-reservoir & 7 & 0.68 \\
Near dam & 9 & 0.87 \\
Near dam & 10 & 0.83 \\
\hline
\end{tabular}

${ }^{1}$ Definitions for abbreviations used in this table:

Inlet $=$

Mid-reservoir $=$

Near dam $=$
Bear River inlet site

mid-reservoir site

deep, near-dam site 
Table 2. Macroinvertebrate analysis of benthic-flux cores taken from Camp Far West Reservoir

\begin{tabular}{|c|c|c|c|c|c|c|c|c|c|c|c|}
\hline \multirow[t]{2}{*}{ Processed with 500 -micrometer sieve ${ }^{1}$} & \multicolumn{5}{|c|}{ April 24, 2002} & \multicolumn{6}{|c|}{ November 4, 2002} \\
\hline & $\begin{array}{cc}\text { Inlet } & \text { Inlet } \\
2 & 4\end{array}$ & $\begin{array}{l}\text { Mid } \\
5\end{array}$ & $\begin{array}{l}\text { Mid } \\
6\end{array}$ & $\begin{array}{c}\text { Dam } \\
10\end{array}$ & $\begin{array}{c}\text { Dam } \\
11\end{array}$ & $\begin{array}{c}\text { Inlet } \\
2\end{array}$ & $\begin{array}{c}\text { Inlet } \\
3\end{array}$ & $\begin{array}{c}\text { Mid } \\
6\end{array}$ & $\begin{array}{c}\text { Mid } \\
7\end{array}$ & $\begin{array}{c}\text { Dam } \\
9\end{array}$ & $\begin{array}{c}\text { Dam } \\
10\end{array}$ \\
\hline $\begin{array}{l}\text { Phylum Nematoda } \\
\qquad \begin{array}{r}\text { Family Mermithidae } \\
\text { undet. mermithid }\end{array}\end{array}$ & & & & & & & & & & 1 & \\
\hline $\begin{array}{l}\text { Phylum Annelida } \\
\text { Class Oligochaeta } \\
\text { Order Tubificida } \\
\text { Family Naididae } \\
\text { Dero digitata } \\
\text { Uncinais uncinata } \\
\text { Family Tubificidae } \\
\text { Bothrioneurum vejdovskyanum } \\
\text { Limnodrilus hoffmeisteri } \\
\text { immature tubificids cf. Limnodrilus } \\
\text { llyodrilus templetoni } \\
\text { immature tubificids cf. I. templetoni }\end{array}$ & $\begin{array}{ll}1 & 2 \\
1 & \\
1 & \end{array}$ & $\begin{array}{l}1 \\
7\end{array}$ & 5 & $\begin{array}{r}3 \\
19 \\
1\end{array}$ & $\begin{array}{r}1 \\
27 \\
1\end{array}$ & 3 & 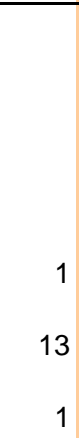 & $\begin{array}{l}3 \\
4\end{array}$ & $\begin{array}{l}1 \\
4\end{array}$ & $\begin{array}{r}1 \\
37\end{array}$ & $\begin{array}{r}39 \\
1\end{array}$ \\
\hline 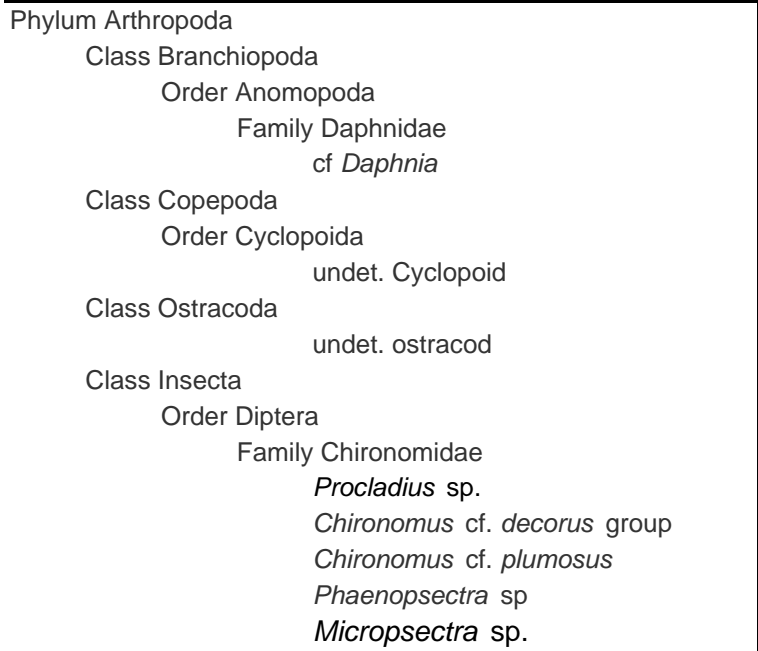 & $\begin{array}{l}1 \\
1 \\
1 \\
1\end{array}$ & 2 & 1 & 1 & 1 & 1 & $\begin{array}{l}1 \\
1\end{array}$ & 1 & 1 & & 2 \\
\hline $\begin{array}{l}\text { Totals } \\
\text { Density (ind-m-2) }\end{array}$ & $\begin{array}{rr}18 & 22 \\
2338 & 2857\end{array}$ & $\begin{array}{r}10 \\
1290\end{array}$ & 7 & 24 & 30 & & & 8 & $\begin{array}{r}6 \\
779\end{array}$ & 39 & $\begin{array}{r}42 \\
5455\end{array}$ \\
\hline $\begin{array}{l}\text { Site Mean Density (ind- }{ }^{-2} \text { ) } \\
\text { Site STD (ind-m }{ }^{-2} \text { ) } \\
\text { Overall Mean Density (ind }-m^{-2} \text { ) } \\
\text { S.D. (ind- } \mathrm{m}^{-2} \text { ) }\end{array}$ & $\begin{array}{r}2597 \\
367 \\
2403 \\
1131\end{array}$ & $\begin{array}{r}1104 \\
275\end{array}$ & 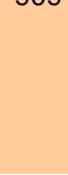 & $\begin{array}{r}3506 \\
551\end{array}$ & 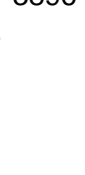 & $\begin{array}{l}1364 \\
1194 \\
2511 \\
2210\end{array}$ & . & $\begin{array}{r}909 \\
184\end{array}$ & 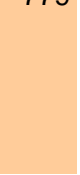 & $\begin{array}{r}5260 \\
275\end{array}$ & 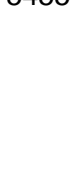 \\
\hline
\end{tabular}

${ }^{1}$ Additional taxa present as inactive stages in all samples, but not counted

Phylum Ectoprocta Pectinatella magnifica (statoblasts)

Phylum Arthropoda Daphnidea spp. (epihippia)

${ }^{2}$ Definitions for abbreviations used in this table:

$\begin{array}{ll}\text { Inlet }= & \text { Bear River inlet site } \\ \text { Mid }= & \text { mid-reservoir site } \\ \text { Dam }= & \text { deep, near-dam site } \\ \text { ind }= & \text { individual macroinvertebrates } \\ \mathrm{m}^{-2}= & \text { per square meter } \\ \text { S.D. }= & \text { standard deviation }\end{array}$


Table 3. Benthic Chlorophyll concentrations for Camp Far West Reservoir, 2002

\begin{tabular}{|ccrr|}
\hline April 24, 2002 & & \multicolumn{2}{c|}{ Chlorophyll-a } \\
\cline { 2 - 3 } Site & $\begin{array}{c}\text { Core } \\
\text { Number }\end{array}$ & $\begin{array}{c}\text { Mean } \\
\left(\mu \mathrm{g}^{-2}\right)\end{array}$ & $\begin{array}{c}\text { S.D. }^{1}{ }^{1} \\
\left(\mu \mathrm{g}^{-\mathrm{cm}^{-2}}\right)\end{array}$ \\
\hline Inlet & 2 & $\mathbf{1 . 5 6}$ & 0.33 \\
Inlet & 4 & $\mathbf{1 . 2 9}$ & 0.05 \\
Mid-reservoir & 5 & $\mathbf{1 . 0 8}$ & 0.72 \\
Mid-reservoir & 6 & $\mathbf{1 . 0 1}$ & 0.20 \\
Near dam & 10 & $\mathbf{1 . 6 3}$ & 0.54 \\
Near dam & 11 & $\mathbf{2 . 4 6}$ & 0.29 \\
\hline
\end{tabular}

\begin{tabular}{|c|c|c|c|}
\hline \multicolumn{2}{|c|}{ November 4, 2002} & \multicolumn{2}{|c|}{ Chlorophyll-a } \\
\hline Site & $\begin{array}{c}\text { Core } \\
\text { Number }\end{array}$ & $\begin{array}{c}\text { Mean } \\
\left(\mu \mathrm{g}-\mathrm{cm}^{-2}\right)\end{array}$ & $\begin{array}{c}\text { S.D. } \\
\left(\mu \mathrm{g}-\mathrm{cm}^{-2}\right)\end{array}$ \\
\hline Inlet & 2 & 1.12 & 0.14 \\
\hline Inlet & 3 & 0.96 & 0.28 \\
\hline Mid-reservoir & 6 & 0.44 & 0.22 \\
\hline Mid-reservoir & 7 & 1.21 & 0.31 \\
\hline Near dam & 9 & 2.38 & 0.79 \\
\hline Near dam & 10 & 2.56 & 0.54 \\
\hline
\end{tabular}

${ }^{1}$ Definitions for abbreviations used in this table:

$\begin{array}{ll}\text { Inlet }= & \text { Bear River inlet site } \\ \text { Mid-reservoir }= & \text { mid-reservoir site } \\ \text { Near dam }= & \text { deep, near-dam site } \\ \text { S.D. }= & \text { standard deviation } \\ \mu \mathrm{g}-\mathrm{cm}^{-2}= & \text { micrograms per square centimeter }\end{array}$


Table 4. Filtered (0.7-micrometer quartz membrane) bottom-water concentrations of mercury species at Camp Far West Reservoir

April 24, 2002

\begin{tabular}{|c|c|c|c|c|c|c|}
\hline \multirow[b]{2}{*}{ Site } & \multicolumn{3}{|c|}{ Methyl-Hg (pM) ${ }^{1}$} & \multicolumn{3}{|c|}{ Total-Hg (pM) } \\
\hline & Ind. Rep. & Site ave. & S.D. & Ind. Rep. & Site ave. & S.D. \\
\hline \multirow[t]{4}{*}{ Inlet } & 0.30 & 0.33 & 0.06 & 14.3 & 15.3 & 1.0 \\
\hline & 0.30 & & & 15.5 & & \\
\hline & 0.31 & & & 16.3 & & \\
\hline & 0.43 & & & & & \\
\hline \multirow[t]{4}{*}{ Mid-reservoir } & $<0.20$ & $<0.20$ & $\mathrm{n} / \mathrm{a}$ & 14.8 & 16.7 & 3.3 \\
\hline & $<0.20$ & & & 15.1 & & \\
\hline & 0.21 & & & 15.3 & & \\
\hline & 0.23 & & & 21.6 & & \\
\hline \multirow[t]{4}{*}{ Near-dam } & 0.21 & 0.23 & 0.01 & 16.6 & 17.4 & 0.7 \\
\hline & 0.22 & & & 17.1 & & \\
\hline & 0.23 & & & 17.7 & & \\
\hline & 0.24 & & & 18.3 & & \\
\hline \multirow[t]{2}{*}{ Near-dam shallow } & $<0.20^{2}$ & 0.20 & $\mathrm{n} / \mathrm{a}$ & 4.5 & & \\
\hline & $<0.20$ & & & $\mathrm{n} / \mathrm{a}$ & & \\
\hline
\end{tabular}

November 4, 2002

\begin{tabular}{|c|c|c|c|c|c|c|}
\hline \multirow[b]{2}{*}{ Site } & \multicolumn{3}{|c|}{ Methyl-Hg (pM) } & \multicolumn{3}{|c|}{ Total-Hg (pM) } \\
\hline & Ind. Rep. & Site ave. & S.D. & Ind. Rep. & Site ave. & S.D. \\
\hline \multirow[t]{4}{*}{ Inlet } & $<0.20$ & $<0.20$ & $\mathrm{n} / \mathrm{a}$ & 3.1 & 3.7 & 0.7 \\
\hline & $<0.20$ & & & 3.2 & & \\
\hline & $<0.20$ & & & 3.8 & & \\
\hline & $<0.20$ & & & 4.6 & & \\
\hline \multirow[t]{4}{*}{ Mid-reservoir } & $<0.20$ & $<0.20$ & $n / a$ & 2.9 & 2.9 & 0.3 \\
\hline & $<0.20$ & & & 3.1 & & \\
\hline & $<0.20$ & & & 2.6 & & \\
\hline & $<0.20$ & & & $n / a$ & & \\
\hline \multirow[t]{3}{*}{ Near dam } & 0.50 & 0.48 & 0.03 & 7.2 & 7.5 & 2.0 \\
\hline & 0.50 & & & 9.6 & & \\
\hline & 0.45 & & & 5.7 & & \\
\hline
\end{tabular}

${ }^{1}$ Definitions for abbreviations used in this table:
Inlet $=$
Mid-reservoir =
Bear River inlet site
Near dam $=$
$\mathrm{pM}=$
mid-reservoir site
deep, near-dam site
Ind. Rep. =
picomolar
ave. $=$
individual sample replicates
S.D. $=$
average
$\mathrm{n} / \mathrm{a}=$
standard deviation
not applicable or not available ${ }^{2}$ The detection limit for the dissolved total-mercury and dissolved
methyl-mercury analysis was $0.20 \mathrm{pM}$. 
Table 5. Flux of mercury species into the water-column of Camp Far West Reservoir

April 24, 2002

\begin{tabular}{|c|c|c|c|c|}
\hline $\begin{array}{l}\text { Methyl-H } \\
\text { Core } \\
\text { Number }\end{array}$ & Station $^{1}$ & $\begin{array}{l}\text { Mercury Flux } \\
\left(\text { pmoles }-\mathrm{m}^{-2}-\mathrm{h}^{-1}\right)\end{array}$ & $\left(n g-m^{-2}-d^{-1}\right)$ & $\begin{array}{l}\text { Site ave. } \\
\left(n g-m^{-2}-d^{-1}\right)\end{array}$ \\
\hline & Inlet & 2.5 & 12.1 & \\
\hline & Inlet & -4.4 & -21.3 & -4.6 \\
\hline & Mid-Res & 0.7 & 3.4 & \\
\hline & Mid-Res & 0.5 & 2.4 & 2.9 \\
\hline & Near dam & 0.5 & 2.6 & \\
\hline & Near Dam & 0.2 & 1.0 & 1.8 \\
\hline
\end{tabular}

\begin{tabular}{|c|c|c|c|c|c|c|c|}
\hline $\begin{array}{l}\text { Total Mercury } \\
\text { Core }\end{array}$ & \multicolumn{5}{|c|}{ Mercury Flux $\left(\right.$ pmoles $\left.-\mathrm{m}^{-2}-\mathrm{h}^{-1}\right)$} & $\begin{array}{l}\text { Mercury Flux } \\
\left(\text { ng }-m^{-2}-d^{-1}\right)\end{array}$ & $\begin{array}{l}\text { Site ave. } \\
\left(n g-m^{-2}-d^{-1}\right)\end{array}$ \\
\hline 2 Inlet & 260 & $+/-$ & 273 & 0.85 & 4 & 1254 & \\
\hline 4 Inlet & 337 & $+/-$ & 394 & 0.82 & 4 & 1623 & 1439 \\
\hline 5 Mid-Res & 308 & $+/-$ & 149 & 0.96 & 4 & 1481 & \\
\hline 6 Mid-Res & $210^{2}$ & $+/-$ & 368 & 0.99 & 3 & 1010 & 1245 \\
\hline 10 Near dam & 306 & $+/-$ & 372 & 0.81 & 4 & 1475 & \\
\hline 11 Near Dam & 272 & $+/-$ & 316 & 0.83 & 4 & 1311 & 1393 \\
\hline
\end{tabular}

November 4, 2002

\begin{tabular}{|cccc|}
\hline $\begin{array}{l}\text { Methyl-Hg } \\
\begin{array}{l}\text { Core } \\
\text { Number }\end{array} \text { Station }\end{array}$ & $\begin{array}{l}\text { Mercury Flux } \\
\left(\text { pmoles- } \mathrm{m}^{-2}-\mathrm{h}^{-1}\right)\end{array}$ & $\begin{array}{l}\text { Site ave. } \\
\left(\mathrm{ng}-\mathrm{nm}^{-2}-\mathrm{d}^{-1}\right)\end{array}$ & $\left.<\mathrm{d}^{-1}\right)$ \\
\hline 2 Inlet & $<0.2$ & $<0.9$ & \\
3 Inlet & $<0.2$ & $<0.9$ & $<0.9$ \\
6 Mid-Res & $<0.2$ & $<0.9$ & \\
7 Mid-Res & $<0.2$ & $<0.9$ & $<0.9$ \\
9 Near dam & $<0.2$ & $<0.9$ & $<0.9$ \\
10 Near Dam & $<0.2$ & $<0.9$ & $<$ \\
\hline
\end{tabular}

\begin{tabular}{|c|c|c|c|c|c|c|c|}
\hline $\begin{array}{l}\text { Total Mercury } \\
\text { Core }\end{array}$ & \multicolumn{5}{|c|}{ Mercury Flux $\left(\right.$ pmoles $\left.-\mathrm{m}^{-2}-\mathrm{h}^{-1}\right)$} & $\begin{array}{l}\text { Mercury Flux } \\
\left(\text { ng }-m^{-2}-d^{-1}\right)\end{array}$ & $\begin{array}{l}\text { Site ave. } \\
\left(n g-m^{-2}-d^{-1}\right)\end{array}$ \\
\hline 2 Inlet & 43 & $+/-$ & 19 & 0.97 & 4 & 209 & \\
\hline 3 Inlet & 106 & $+/-$ & 52 & 0.96 & 4 & 508 & 359 \\
\hline 6 Mid-Res & 124 & $+/-$ & 161 & 0.79 & 4 & 597 & \\
\hline 7 Mid-Res & 195 & $+/-$ & 158 & 0.91 & 4 & 938 & 767 \\
\hline 9 Near dam & 36 & $+/-$ & 163 & 0.24 & 4 & 175 & \\
\hline 10 Near Dam & -28 & $+/-$ & 13 & 0.97 & 4 & -137 & 19 \\
\hline
\end{tabular}

${ }^{1}$ Definitions for abbreviations used in this table:

$\begin{array}{ll}\text { Inlet }= & \text { Bear River inlet site } \\ \text { Mid-Res }= & \text { mid-reservoir site } \\ \text { Near dam }= & \text { deep, near-dam site } \\ \text { Site ave. }= & \text { site average } \\ \mathrm{ci}= & \text { 95-percent confidence interval } \\ \mathrm{r} \text {-squared }= & \text { coefficient of determination for flux regression } \\ \text { pmoles- } \mathrm{m}^{-2}-\mathrm{h}^{-1}= & \text { picomoles per square meter per hour } \\ \mathrm{ng}-\mathrm{m}^{-2}-\mathrm{d}^{-1}= & \text { nanograms per square meter per day }\end{array}$

2 The flux calculation did not include the concentration at the final increment because it was approximately 10 standard deviations greater than the mean for the final time increment from the other April cores. With this outlier included, the flux was 1,217 $+/-16,940$ pmoles $-\mathrm{m}^{-2}-\mathrm{h}^{-1}$. 


\section{Benthic-Flux of Dissolved Nutrients}

\section{April 24, 2002}

\begin{tabular}{|c|c|c|c|c|c|c|}
\hline \multicolumn{7}{|l|}{ Nitrite } \\
\hline \multicolumn{2}{|l|}{ Core } & \multicolumn{5}{|c|}{$\mathrm{NO}_{2}$ Flux $\left(\mu\right.$ moles $\left.-\mathrm{m}^{-2} \mathrm{~h}^{-1}\right)$} \\
\hline Number & Site & mean & & $\mathrm{ci}$ & $r^{2}$ & $\mathrm{n}$ \\
\hline 2 & Inlet & 1.4 & $+1-$ & 1.6 & 0.69 & 5 \\
\hline 4 & Inlet & 2.3 & $+1-$ & 2.0 & 0.79 & 5 \\
\hline $5^{2}$ & Mid-Res & 1.3 & $+1-$ & 2.0 & 0.36 & 5 \\
\hline 6 & Mid-Res & 2.3 & + +- & 3.0 & 0.63 & 4 \\
\hline 10 & Near dam & 6.1 & +- & 2.3 & 0.95 & 4 \\
\hline 11 & Near dam & 5.1 & $+1-$ & 2.6 & 0.92 & 4 \\
\hline
\end{tabular}

\begin{tabular}{|c|c|c|c|c|c|c|}
\hline \multicolumn{7}{|c|}{ Nitrate plus Nitrite } \\
\hline \multirow{2}{*}{$\begin{array}{l}\text { Core } \\
\text { Number }\end{array}$} & \multicolumn{6}{|c|}{$\mathrm{NO}_{3}$ Flux $\left(\mu\right.$ moles $\left.-m^{-2} h^{-1}\right)$} \\
\hline & Site & mean & & $\mathrm{ci}$ & $r^{2}$ & $\mathrm{n}$ \\
\hline 2 & Inlet & -66.6 & $+1-$ & 107.1 & 0.53 & 5 \\
\hline 4 & Inlet & -34.7 & $+/-$ & 55.4 & 0.53 & 5 \\
\hline $5^{2}$ & Mid-Res & -0.7 & $+1-$ & 4.4 & 0.03 & 5 \\
\hline 6 & Mid-Res & -78.0 & $+1-$ & 34.9 & 0.94 & 4 \\
\hline 10 & Near dam & -64.0 & $+/-$ & 88.8 & 0.60 & 4 \\
\hline 11 & Near dam & 64.6 & $+1-$ & 28.7 & 0.97 & 4 \\
\hline
\end{tabular}

\begin{tabular}{|c|c|c|c|c|c|c|}
\hline \multicolumn{7}{|c|}{ Ammonia } \\
\hline \multirow{2}{*}{$\begin{array}{l}\text { Core } \\
\text { Number }\end{array}$} & \multicolumn{6}{|c|}{$\mathrm{NH}_{4}$ Flux $\left(\mu\right.$ moles $\left.-\mathrm{m}^{-2} \mathrm{~h}^{-1}\right)$} \\
\hline & Site & mean & & $\mathrm{ci}$ & $r^{2}$ & $\mathrm{n}$ \\
\hline 2 & Inlet & 92 & $+1-$ & 32 & 0.96 & 5 \\
\hline 4 & Inlet & 92 & $+1-$ & 86 & 0.77 & 5 \\
\hline $5^{2}$ & Mid-Res & 8 & $+1-$ & 70 & 0.02 & 5 \\
\hline 6 & Mid-Res & 38 & $+1-$ & 20 & 0.92 & 4 \\
\hline 10 & Near dam & 184 & $+1-$ & 59 & 0.97 & 4 \\
\hline 11 & Near dam & 241 & $+1-$ & 84 & 0.96 & 4 \\
\hline
\end{tabular}

\begin{tabular}{|c|c|c|c|c|c|c|}
\hline \multicolumn{7}{|c|}{ Dissolved Inorganic Nitrogen (DIN) } \\
\hline \multirow{2}{*}{$\begin{array}{l}\text { Core } \\
\text { Number }\end{array}$} & \multicolumn{6}{|c|}{ DIN Flux $\left(\mu\right.$ moles $\left.-m^{-2}-h^{-1}\right)$} \\
\hline & Site & mean & & $\mathrm{ci}$ & $r^{2}$ & $\mathrm{n}$ \\
\hline 2 & Inlet & 57 & $+1-$ & 29 & 0.92 & 5 \\
\hline 4 & Inlet & 57 & $+1-$ & 137 & 0.34 & 5 \\
\hline $5^{2}$ & Mid-Res & -57 & $+1-$ & 270 & 0.06 & 5 \\
\hline 6 & Mid-Res & -40 & $+1-$ & 16 & 0.95 & 4 \\
\hline 10 & Near dam & 120 & $+1-$ & 118 & 0.75 & 4 \\
\hline 11 & Near dam & 305 & $+1-$ & 108 & 0.96 & 4 \\
\hline
\end{tabular}

\begin{tabular}{|c|c|c|c|c|c|c|}
\hline \multicolumn{7}{|c|}{ Orthophosphate } \\
\hline \multirow{2}{*}{$\begin{array}{l}\text { Core } \\
\text { Number }\end{array}$} & & \multicolumn{5}{|c|}{$\mathrm{PO}_{4}$ Flux $\left(\mu\right.$ moles $\left.-\mathrm{m}^{-2}-\mathrm{h}^{-1}\right)$} \\
\hline & Site & mean & & ci & $r^{2}$ & $\mathrm{n}$ \\
\hline 2 & Inlet & -0.43 & $+1-$ & 0.25 & 0.90 & 5 \\
\hline 4 & Inlet & 0.29 & $+/-$ & 0.63 & 0.38 & 5 \\
\hline $5^{2}$ & Mid-Res & 0.07 & $+1-$ & 1.45 & 0.01 & 5 \\
\hline 6 & Mid-Res & -0.21 & $+1-$ & 0.68 & 0.22 & 4 \\
\hline 10 & Near dam & -0.42 & $+/-$ & 0.13 & 0.97 & 4 \\
\hline 11 & Near dam & -0.23 & $+1-$ & 0.91 & 0.16 & 4 \\
\hline
\end{tabular}

\begin{tabular}{|c|c|c|c|c|c|c|}
\hline \multicolumn{7}{|l|}{ Silica } \\
\hline \multirow{2}{*}{$\begin{array}{l}\text { Core } \\
\text { Number }\end{array}$} & \multicolumn{6}{|c|}{ Si Flux $\left(\mu\right.$ moles $\left.-m^{-2} h^{-1}\right)$} \\
\hline & Site & mean & & $\mathrm{ci}$ & $r^{2}$ & $\mathrm{n}$ \\
\hline 2 & Inlet & 799 & $+1-$ & 782 & 0.75 & 5 \\
\hline 4 & Inlet & 755 & $+1-$ & 769 & 0.74 & 5 \\
\hline $5^{2}$ & Mid-Res & -100 & $+1-$ & 95 & 0.61 & 5 \\
\hline 6 & Mid-Res & -46 & $+1-$ & 77 & 0.51 & 4 \\
\hline 10 & Near dam & 100 & $+1-$ & 83 & 0.81 & 4 \\
\hline 11 & Near dam & 157 & $+1-$ & 73 & 0.93 & 4 \\
\hline
\end{tabular}

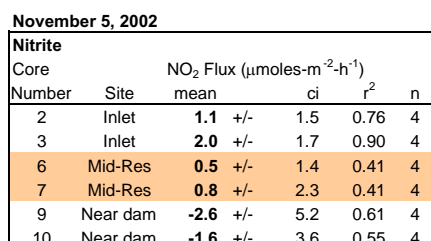

\begin{tabular}{|c|c|c|c|c|c|c|}
\hline \multicolumn{6}{|c|}{ Nitrate plus Nitrite } & \\
\hline \multirow{2}{*}{$\begin{array}{l}\text { Core } \\
\text { Number }\end{array}$} & \multirow[b]{2}{*}{ Site } & \multicolumn{4}{|c|}{$\mathrm{NO}_{3}$ Flux $\left(\mu\right.$ moles $\left.-\mathrm{m}^{-2}-\mathrm{h}^{-1}\right)$} & \\
\hline & & mean & & $\mathrm{ci}$ & $r^{2}$ & \\
\hline 2 & Inlet & -5.4 & $+1-$ & 23.9 & 0.24 & \\
\hline 3 & Inlet & 15.4 & $+1-$ & 82.2 & 0.18 & 4 \\
\hline 6 & Mid-Res & -39.0 & $+1-$ & 56.6 & 0.75 & 4 \\
\hline 7 & Mid-Res & 10.7 & $+1-$ & 56.4 & 0.19 & 4 \\
\hline 9 & Near dam & 217.8 & $+1-$ & 413.3 & 0.64 & \\
\hline
\end{tabular}

\begin{tabular}{|c|c|c|c|c|c|c|}
\hline & \\
\hline \multirow{2}{*}{$\begin{array}{l}\text { Ammoni } \\
\text { Core } \\
\text { Number }\end{array}$} & \multicolumn{6}{|c|}{$\mathrm{NH}_{4}$ Flux $\left(\mu\right.$ moles $\left.-\mathrm{m}^{-2} \mathrm{~h}^{-1}\right)$} \\
\hline & \multirow{2}{*}{$\frac{\text { Site }}{\text { Inlet }}$} & \multirow{2}{*}{$\begin{array}{r}\text { mean } \\
207\end{array}$} & \multirow[b]{2}{*}{$+1-$} & \multirow{2}{*}{$\begin{array}{r}\mathrm{ci} \\
129\end{array}$} & & \\
\hline 2 & & & & & & 4 \\
\hline 3 & Inlet & 154 & $+1-$ & 120 & 0.91 & 4 \\
\hline 6 & Mid-Re & 124 & $+1-$ & 206 & 0.70 & 4 \\
\hline 7 & Mid-Res & 211 & $+1-$ & 95 & 0.97 & 4 \\
\hline & Near d & 112 & $+1-$ & 1157 & 0.06 & \\
\hline
\end{tabular}

\begin{tabular}{|c|c|c|c|c|c|c|}
\hline \multicolumn{6}{|c|}{ Dissolved Inorganic Nitrogen (DIN) } & \\
\hline \multirow{2}{*}{$\begin{array}{l}\text { Core } \\
\text { Number }\end{array}$} & \multicolumn{6}{|c|}{ DIN Flux $\left(\mu\right.$ moles $\left.-m^{-2}-h^{-1}\right)$} \\
\hline & Site & mean & & $\mathrm{ci}$ & $r^{2}$ & \\
\hline 2 & Inlet & 201 & $+1-$ & 109 & 0.96 & \\
\hline 3 & Inlet & 169 & $+1-$ & 190 & 0.84 & \\
\hline 6 & Mid-Res & 93 & $+1-$ & 243 & 0.49 & \\
\hline 7 & Mid-Res & 68 & $+1-$ & 90 & 0.78 & \\
\hline 9 & Near dam & 331 & $+1-$ & 1504 & 0.24 & \\
\hline 10 & Near dam & -4 & $+1-$ & 58 & 0.04 & \\
\hline
\end{tabular}

\begin{tabular}{|c|c|c|c|c|c|c|}
\hline \multicolumn{2}{|c|}{ Orthophosphate } & \multirow{2}{*}{\multicolumn{4}{|c|}{$\mathrm{PO}_{4}$ Flux $\left(\mu\right.$ moles $\left.-\mathrm{m}^{-2}-\mathrm{h}^{-1}\right)$}} & \multirow[b]{3}{*}{$\mathrm{n}$} \\
\hline Core & & & & & & \\
\hline Number & Site & mean & & $\mathrm{ci}$ & $r^{2}$ & \\
\hline 2 & Inlet & 0.40 & +- & 0.61 & 0.73 & 4 \\
\hline 3 & Inlet & 0.16 & +- & 0.58 & 0.33 & 4 \\
\hline 6 & Mid-Res & 0.55 & $+1-$ & 1.16 & 0.59 & 4 \\
\hline 7 & Mid-Res & 0.51 & $+1-$ & 1.55 & 0.41 & 4 \\
\hline 9 & Near dam & -0.18 & $+1-$ & 1.89 & 0.05 & 4 \\
\hline 10 & Near dam & 0.33 & $+1-$ & 1.13 & 0.35 & 4 \\
\hline
\end{tabular}

\begin{tabular}{|c|c|c|c|c|c|c|}
\hline \\
\hline \multirow{2}{*}{$\begin{array}{l}\text { Silica } \\
\text { Core } \\
\text { Number }\end{array}$} & \multicolumn{6}{|c|}{ Si Flux $\left(\mu\right.$ moles $\left.-m^{-2}-h^{-1}\right)$} \\
\hline & Site & mean & & $\mathrm{ci}$ & $r^{2}$ & $\mathrm{n}$ \\
\hline 2 & Inlet & 52 & $+1-$ & 166 & 0.22 & 4 \\
\hline 3 & Inlet & -52 & $+1-$ & 29 & 0.90 & 4 \\
\hline 6 & Mid-Res & 86 & $+1-$ & 38 & 0.94 & 4 \\
\hline 7 & Mid-Res & 160 & $+1-$ & 121 & 0.84 & 4 \\
\hline 9 & Near dam & -213 & $+1-$ & 178 & 0.81 & 4 \\
\hline 10 & Near dam & 39 & $+1-$ & 475 & 0.04 & 4 \\
\hline
\end{tabular}

Water-column Dissolved Nutrients (micromolar) April 24, 2002

\begin{tabular}{ll|r|r|r|r|r|r|r|r|} 
& Relative & Depth & & Nitrate + & Ortho- & & Inorganic \\
Site & Depth & $(\mathrm{m})$ & Nitrite & Nitrite & $\begin{array}{r}\text { Molar } \\
\text { phosphate }\end{array}$ & Silica & Ammonia & Nitrogen & N:P Ratio \\
\hline Inlet & Surface & 1 & 0.19 & 3.3 & 0.02 & 149 & 1.57 & 4.88 & 244 \\
& Mid & 14 & 0.08 & 3.2 & 0.02 & 166 & 1.66 & 4.86 & 243 \\
& Deep & 28 & 0.20 & 15.7 & 0.08 & 177 & 0.62 & 16.33 & 204 \\
Mid-Res & Surface & 1 & 0.21 & 3.5 & 0.00 & 145 & 1.02 & 4.48 & \\
& Mid & 12 & 0.38 & 15.2 & 0.02 & 175 & 0.45 & 15.69 & 785 \\
& Deep & 24 & 0.08 & 21.6 & 0.16 & 181 & 0.14 & 21.76 & 136 \\
\multirow{2}{*}{ Near dam } & Surface & 1 & 0.20 & 3.6 & 0.00 & 149 & 1.25 & 4.86 & \\
& Mid & 21 & 0.15 & 4.7 & 0.00 & 163 & 1.47 & 6.16 & \\
& Deep & 43 & 0.14 & 17.0 & 0.03 & 178 & 0.23 & 17.23 & 574
\end{tabular}

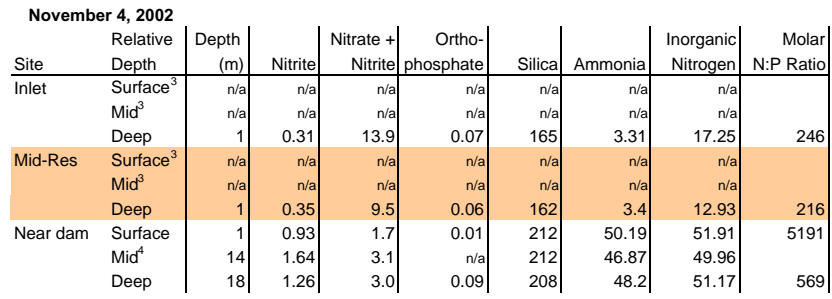

${ }^{1}$ Definitions for abbreviations used in this table:

Inlet $=\quad$ Bear River inlet site

Mid-Res $=\quad$ mid-reservoir site

Near dam $=\quad$ deep, near-dam site

$\mathrm{ci}=\quad 95$-percent confidence interval

$\mathrm{r}^{2}=\quad$ coefficient of determination for flux regression

$n=\quad$ analytical replicates used in flux determination

$n g-\mathrm{m}^{-2}-\mathrm{d}^{-1}=\quad$ nanograms per square meter per day

umoles $-m^{-2} h^{-1}=$ micromoles per square meter per hour

$\mathrm{m}=\quad$ meters

n/a $=\quad$ not applicable or not available

${ }^{2}$ For mid-reservoir site in April 2002, Core 5 was anomalous in terms of routinely non-linear time series for all solutes except silica.

${ }^{3}$ Site depth was only 2 meters to accommodate the draft of the sampling vesse

${ }^{4}$ In contrast to other mid-depth sampling (typically half of overall site depth), this depth was selected just above the oxycline (Fig. 4) 


\begin{tabular}{|c|c|c|c|c|c|c|c|c|c|c|c|c|c|c|c|}
\hline \multicolumn{2}{|c|}{$\begin{array}{l}\text { April 24, } 2002 \\
\text { Core }\end{array}$} & \multicolumn{3}{|c|}{ Sulfide Flux (nmoles- $\left.m^{-2}-h^{-1}\right)$} & \multirow[b]{2}{*}{ Site ave. } & \multirow[b]{2}{*}{ r-squared } & \multirow{2}{*}{\multicolumn{2}{|c|}{$\begin{array}{l}\text { Pore-water } \\
\text { Sulfide }^{2}(\mu \mathrm{M})\end{array}$}} & \multirow[b]{2}{*}{ S.D. } & \multirow{2}{*}{$\begin{array}{r}\text { Bottom- } \\
\text { water } \\
\text { Sulfide }^{3}(\mathrm{nM})\end{array}$} & \multirow{2}{*}{$\begin{array}{c}\text { Concentration } \\
\text { Gradient } \\
\left(\mathrm{nM}-\mathrm{cm}^{-1}\right)\end{array}$} & \multirow{2}{*}{$\begin{array}{r}\text { Distance } \\
(\mathrm{cm})\end{array}$} & \multirow{2}{*}{$\begin{array}{r}\text { Calculated } \\
\text { Diffusive Flux } \\
\left(n \text { nmoles}^{4}-m^{-2}-h^{-1}\right)\end{array}$} & \multirow{2}{*}{$\begin{array}{r}\text { Measured } \\
\text { Sulfide Flux } \\
\left(n \text { moles }-\mathrm{m}^{-2}-\mathrm{h}^{-1}\right)\end{array}$} & \multirow[t]{2}{*}{$\begin{array}{r}\text { Map code } \\
\text { (Fig. 1) }\end{array}$} \\
\hline Number & Site $^{1}$ & mean & & $\mathrm{ci}$ & & & & & & & & & & & \\
\hline 2 & Inlet & 427.7 & $+1-$ & 33.6 & & 0.97 & 8 & & & & & & & & \\
\hline 4 & Inlet & 535.5 & $+1-$ & 64.5 & 481.6 & 0.94 & 8 & 0.0 & 0.0 & 3.93 & -2 & 2 & -1 & 419 & 1 \\
\hline 5 & Mid-Res & 323.7 & $+1-$ & 29.5 & & 0.96 & 8 & & & & & & & & \\
\hline 6 & Mid-Res & 382.6 & $+1-$ & 42.3 & 353.1 & 0.94 & 8 & 1.6 & 1.3 & 4.47 & 798 & 2 & 287 & 424 & 2 \\
\hline 10 & Near dam & 287.1 & $+1-$ & 46.7 & & 0.92 & 9 & & & & & & & & \\
\hline 11 & Near dam & 296.4 & $+1-$ & 14.3 & 291.8 & 0.99 & 9 & 0.1 & 0.0 & 3.51 & 48 & 2 & 17 & 616 & 3 \\
\hline
\end{tabular}

\begin{tabular}{|c|c|c|c|c|c|c|c|c|c|c|c|c|c|c|c|}
\hline \multirow{2}{*}{\multicolumn{8}{|c|}{$\begin{array}{l}\text { November 4, } 2002 \\
\text { Core }\end{array}$}} & \multirow{2}{*}{\multicolumn{2}{|c|}{$\begin{array}{l}\text { Pore-water } \\
\text { Sulfide }^{2}(\mu \mathrm{M})\end{array}$}} & \multirow{2}{*}{$\begin{array}{r}\text { Bottom- } \\
\text { water }\end{array}$} & \multicolumn{2}{|l|}{ Concentration } & \multirow{3}{*}{$\begin{array}{r}\text { Calculated } \\
\text { Diffusive Flux } \\
\left(n \text { moles- } \mathrm{m}^{-2}-\mathrm{h}^{-1}\right)\end{array}$} & \multirow{3}{*}{$\begin{array}{r}\text { Measured } \\
\text { Sulfide Flux } \\
\left(\mathrm{nmoles}-\mathrm{m}^{-2}-\mathrm{h}^{-1}\right)\end{array}$} & \multirow{3}{*}{$\begin{array}{r}\text { Map code } \\
\text { (Fig. 1) }\end{array}$} \\
\hline & & & $(\mathrm{nm}$ & & & & & & & & Gradient & Distance & & & \\
\hline Number & Site & $\frac{\text { mean }}{4459}$ & +1 & $\frac{\mathrm{ci}}{260}$ & Site ave. & r-squared & $\frac{n}{8}$ & Site ave. & S.D. & Sulfide $^{3}(\mathrm{nM})$ & $\left(\mathrm{nM}-\mathrm{cm}^{-1}\right)$ & & & & \\
\hline $\begin{array}{l}2 \\
3\end{array}$ & Inlet & 518.8 & $+1-$ & 61.2 & 482.3 & 0.94 & 8 & 0.4 & 0.1 & 0 & 200 & 2 & 72 & 419 & $1^{\prime}$ \\
\hline 6 & Mid-Res & 570.4 & $+1-$ & 23.5 & & 0.99 & 8 & & & & & & & & \\
\hline 7 & Mid-Res & 491.8 & $+1-$ & 21.7 & 531.1 & 0.99 & 8 & 0.8 & 0.2 & 0 & 400 & 2 & 144 & 424 & $2^{\prime}$ \\
\hline 9 & Near dam & 1188.0 & $+1-$ & 68.4 & & 0.98 & 9 & & & & & & & & \\
\hline 10 & Near dam & 1178.5 & $+1-$ & 35.8 & 1183.3 & 0.99 & 9 & 0.4 & 0.1 & 0 & 200 & 2 & 72 & 616 & 3 \\
\hline
\end{tabular}

${ }^{1}$ Definitions for abbreviations used in this table:

$\begin{array}{ll}\text { Inlet }= & \text { Bear River inlet site } \\ \text { Mid-Res }= & \text { mid-reservoir site } \\ \text { Near dam }= & \text { deep, near-dam site } \\ \text { Site ave. }= & \text { site average } \\ \mathrm{ci}= & \text { 95-percent confidence interval } \\ \mathrm{r} \text {-squared }= & \text { coefficient of determination for flux regression } \\ \mathrm{n}= & \text { analytical replicates used in flux determination } \\ \mathrm{cm}= & \text { centimeter } \\ \mathrm{nmoles}-\mathrm{m}^{-2}-\mathrm{h}^{-1}= & \text { nanomoles per square meter per hour } \\ \mu \mathrm{M}= & \text { micromoles per liter } \\ \mathrm{nM}= & \text { nanomoles per liter }\end{array}$

${ }^{2}$ Porewater sulfides were determined by ion-selective electrode.

${ }^{3}$ The zero value for bottom-water sulfide indicates a concentration not statistically different than zero (or $<2 \mathrm{nM}$ ) with the voltammetric analysis.

${ }^{4}$ Diffusive flux was based on a diffusion coefficient $=$ $1.00 \mathrm{E}-05 \mathrm{~cm}^{2} \mathrm{~s}^{-1}$ (Li and Gregory, 1974) 
Table 8. Benthic flux values and water-column concentrations for dissolved organic carbon (DOC) at Camp Far West Reservoir, CA

\section{April 24, 2002}

\begin{tabular}{|rcrrrr|}
\hline $\begin{array}{r}\text { Benthic Flux } \\
\text { Core } \\
\text { Number }\end{array}$ & Site & \multicolumn{2}{c|}{$\begin{array}{c}\text { DOC Flux } \\
\left(\mu \text { moles- }{ }^{-2}-h^{-1}\right)\end{array}$} \\
\hline 2 & Inlean & $\mathbf{5 7}+/-$ & 68 & 0.04 & $\mathbf{n}$ \\
4 & Inlet & $\mathbf{1 6 7 + / -}$ & 41 & 0.42 & 14 \\
5 & Mid-Res & $\mathbf{- 2 0 3 + / -}$ & 28 & 0.64 & 15 \\
6 & Mid-Res & $\mathbf{- 1 1 4 + / -}$ & 19 & 0.47 & 17 \\
10 & Near dam & $\mathbf{2 4 2 + / -}$ & 31 & 0.80 & 12 \\
11 & Near dam & $\mathbf{3 7 3 + / -}$ & 42 & 0.74 & 15 \\
\hline
\end{tabular}

\begin{tabular}{|c|c|c|c|c|c|c|}
\hline \multicolumn{7}{|l|}{ Water Column } \\
\hline Site & $\begin{array}{r}\text { Depth } \\
\text { (relative) }\end{array}$ & $\begin{array}{r}\text { Depth } \\
(\mathrm{m})\end{array}$ & $\begin{array}{l}\text { DOC } \\
(\mu \mathrm{M})\end{array}$ & & $\begin{array}{r}\text { ci } \\
(\mu \mathrm{M})\end{array}$ & $\mathrm{n}$ \\
\hline \multirow[t]{3}{*}{ Inlet } & Surface & 1 & 170.4 & $+/-$ & 3.3 & 4 \\
\hline & Mid-depth & 14 & 126.2 & $+1-$ & 2.5 & 5 \\
\hline & Deep & 28 & 159.8 & $+/-$ & 0.8 & 4 \\
\hline \multirow[t]{3}{*}{ Mid-Res } & Surface & 1 & 162.5 & $+1-$ & 1.2 & 3 \\
\hline & Mid-depth & 12 & 150.3 & $+1-$ & 0.9 & 3 \\
\hline & Deep & 24 & 173.8 & $+1-$ & 0.4 & 3 \\
\hline \multirow[t]{3}{*}{ Near dam } & Surface & 1 & 185.0 & $+/-$ & 1.9 & 4 \\
\hline & Mid-depth & 21 & 185.8 & $+1-$ & 3.2 & 3 \\
\hline & Deep & 43 & 184.3 & $+1-$ & 0.7 & 4 \\
\hline
\end{tabular}

\section{November 4, 2002}

\begin{tabular}{|c|c|c|c|c|c|}
\hline $\begin{array}{r}\text { Benthic Flux } \\
\text { Core } \\
\text { Number }\end{array}$ & Site & \multicolumn{2}{|c|}{$\begin{array}{c}\text { DOC Flux } \\
\left(\mu \text { moles }-\mathrm{m}^{-2}-\mathrm{h}^{-1}\right)\end{array}$} & r-squared & $\mathbf{n}$ \\
\hline 2 & Inlet & $36+/-$ & 15 & 0.23 & 13 \\
\hline 3 & Inlet & $17+/-$ & 32 & 0.01 & 14 \\
\hline 6 & Mid-Res & $-23+/-$ & 23 & 0.04 & 15 \\
\hline 7 & Mid-Res & $-9+1-$ & 81 & 0.00 & 12 \\
\hline 9 & Near dam & $452+/-$ & 47 & 0.80 & 14 \\
\hline 10 & Near dam & $584+/-$ & 51 & 0.82 & 15 \\
\hline
\end{tabular}

\begin{tabular}{|c|c|c|c|c|c|c|}
\hline \multicolumn{7}{|l|}{ Water Column } \\
\hline Site & $\begin{array}{r}\text { Depth } \\
\text { (relative) }\end{array}$ & $\begin{array}{r}\text { Depth } \\
(\mathrm{m})\end{array}$ & $\begin{array}{r}\text { DOC } \\
(\mu \mathrm{M})\end{array}$ & & $\begin{array}{r}c i \\
(\mu \mathrm{M})\end{array}$ & $\mathbf{n}$ \\
\hline \multirow{3}{*}{ Inlet } & Surface & $\mathrm{n} / \mathrm{a}^{3}$ & $n / a^{3}$ & & $n / a^{3}$ & \\
\hline & Mid-depth & $n / a^{3}$ & $\mathrm{n} / \mathrm{a}^{3}$ & & $n / a^{3}$ & \\
\hline & Deep & 1 & 222.4 & $+/-$ & 0.2 & 3 \\
\hline \multirow[t]{3}{*}{ Mid-Res } & Surface & $n / a^{3}$ & $n / a^{3}$ & & $n / a^{3}$ & \\
\hline & Mid-depth & $n / a^{3}$ & $\mathrm{n} / \mathrm{a}^{3}$ & & $n / a^{3}$ & \\
\hline & Deep & 1 & 210.6 & $+/-$ & 3.5 & 4 \\
\hline \multirow{3}{*}{ Near dam } & Surface & 1 & 198.6 & $+/-$ & 3.2 & 4 \\
\hline & Above oxycline $^{4}$ & 14 & 193.7 & $+/-$ & 4.6 & 4 \\
\hline & Deep & 18 & 187.0 & $+/-$ & 2.6 & 4 \\
\hline
\end{tabular}

${ }^{1}$ Definitions for abbreviations used in this table:

$$
\begin{aligned}
& \text { Inlet }= \\
& \text { Mid-Res }= \\
& \text { Near dam }= \\
& \text { Site ave. }= \\
& \mathrm{ci}= \\
& \mathrm{r} \text {-squared }= \\
& \mathrm{m}= \\
& \mathrm{n}= \\
& \mu \mathrm{moles}-\mathrm{m}^{-2}-\mathrm{h}^{-1} \\
& \mu \mathrm{M}=
\end{aligned}
$$

\section{Bear River inlet site}

mid-reservoir site

deep, near-dam site

site average

95-percent confidence interval

coefficient of determination for flux regression

meter

analytical replicates used in flux determination

micromoles of DOC (in terms of carbon) per square meter per hour

micromoles of DOC (in terms of carbon) per liter

${ }^{2}$ All 12 hours used in DOC flux calculations

${ }^{3}$ Not available because the site depth was only 2 meters to accommodate the draft of the sampling vessel

${ }^{4}$ For its potential chemical significance, mid-depth was taken just above the oxycline. 
Table 9. Water-column concentrations (mean and deviation) of photosynthetic pigments and stable isotopic and elemental composition of suspended particulate material (SPM) in Camp Far West reservoir.

\begin{tabular}{|c|c|c|c|c|c|c|c|c|c|c|c|}
\hline \multirow{3}{*}{ October 30, 2001} & \multirow[b]{3}{*}{ Inlet } & \multirow{2}{*}{\multicolumn{2}{|c|}{$\begin{array}{c}\text { Chlorophyll-a } \\
\left(\mu \mathrm{g}-\mathrm{L}^{-1}\right)\end{array}$}} & \multirow{2}{*}{\multicolumn{2}{|c|}{$\begin{array}{c}\text { Pheophytin } \\
\left(\mu \mathrm{g}-\mathrm{L}^{-1}\right)\end{array}$}} & \multirow{3}{*}{$\begin{array}{c}\text { Pheo/Chl } \\
0.290\end{array}$} & \multirow{3}{*}{$\frac{\text { Chl/(Chl + Pheo) }}{0.775}$} & \multicolumn{4}{|c|}{ Suspended Particulate Material (SPM) } \\
\hline & & & & & & & & \multicolumn{2}{|c|}{$\delta^{13} \mathrm{C}$} & $\delta^{15} \mathrm{~N}$ & Molar C:N \\
\hline & & 13.2 & \pm 0.4 & 3.8 & \pm 0.1 & & & -31.07 & \pm 0.22 & $4.81 \pm 0.31$ & $7.95 \pm 0.01$ \\
\hline & Mid-Res & 10.5 & \pm 0.8 & 2.9 & \pm 0.0 & 0.278 & 0.783 & -30.93 & \pm 0.03 & $6.35 \pm 0.65$ & $8.15 \pm 0.18$ \\
\hline & Near dam & 6.8 & \pm 0.1 & 2.5 & \pm 0.1 & 0.367 & 0.732 & -30.67 & \pm 0.13 & $6.88 \pm 0.01$ & $8.57 \pm 0.46$ \\
\hline \multirow[t]{3}{*}{ February 13, 2002} & Inlet & 8.7 & \pm 0.2 & 1.9 & \pm 0.3 & 0.222 & 0.819 & -33.23 & \pm 0.02 & $10.64 \pm 0.01$ & $6.08 \pm 0.03$ \\
\hline & Mid-Res & 9.7 & \pm 0.1 & 2.1 & \pm 0.3 & 0.214 & 0.824 & -33.80 & \pm 0.30 & $7.45 \pm 1.45$ & $6.37 \pm 0.24$ \\
\hline & Near dam & 11.1 & \pm 1.0 & 2.3 & \pm 0.1 & 0.203 & 0.831 & -33.52 & \pm 0.28 & $6.57 \pm 0.15$ & $6.37 \pm 0.04$ \\
\hline \multirow[t]{3}{*}{ April 23, 2002} & Inlet & 2.6 & \pm 0.1 & 0.4 & \pm 0.0 & 0.170 & 0.855 & -28.65 & \pm 0.07 & $1.94 \pm 0.19$ & $7.14 \pm 0.12$ \\
\hline & Mid-Res & 1.6 & \pm 0.2 & 0.2 & \pm 0.0 & 0.103 & 0.906 & -28.24 & \pm 0.13 & $3.14 \pm 0.37$ & $8.78 \pm 0.16$ \\
\hline & Near dam & 1.9 & \pm 0.1 & 0.3 & \pm 0.0 & 0.158 & 0.863 & -27.75 & \pm 0.05 & $3.65 \pm 0.36$ & $8.20 \pm 0.02$ \\
\hline \multirow[t]{3}{*}{ August 6, 2002} & Inlet & 4.3 & \pm 0.2 & 2.3 & \pm 0.1 & 0.521 & 0.658 & & & & \\
\hline & Mid-Res & 3.3 & \pm 0.2 & 1.7 & \pm 0.2 & 0.522 & 0.659 & & & & \\
\hline & Near dam & 3.3 & \pm 0.1 & 0.9 & \pm 0.3 & 0.279 & 0.786 & & & & \\
\hline \multirow[t]{3}{*}{ November 5, 2002} & Inlet & 30.4 & \pm 0.6 & 18.0 & \pm 0.2 & 0.590 & 0.629 & & & & \\
\hline & Mid-Res & 19.7 & \pm 0.4 & 9.7 & \pm 0.2 & 0.494 & 0.669 & & & & \\
\hline & Near dam & 12.6 & 0.0 & 6.6 & \pm 0.1 & 0.526 & 0.655 & & & & \\
\hline \multirow[t]{3}{*}{ January 29, 2003} & Inlet & 4.4 & \pm 0.2 & 2.7 & \pm 0.1 & 0.621 & 0.617 & & & & \\
\hline & Mid-Res & 16.8 & \pm 2.7 & 8.4 & \pm 0.6 & 0.510 & 0.663 & & & & \\
\hline & Near dam & 11.0 & \pm 0.2 & 6.6 & \pm 0.3 & 0.597 & 0.626 & & & & \\
\hline
\end{tabular}

${ }^{1}$ Definitions for abbreviations used in this table:

Inlet $=$

Mid-Res =

Near dam $=$

$\mu \mathrm{g}-\mathrm{L}^{-1}=$

$\mathrm{Pheo} / \mathrm{Chl}=$

$\mathrm{Chl} /(\mathrm{Chl}+\mathrm{Pheo})=$
Bear River inlet site

mid-reservoir site

deep, near-dam site

micrograms per lite

concentration ratio of pheophytin over chlorophyll-a

concentration ratio of chlorophyll-a over the sum of chorophyll-a and pheophytin 
Table 10. Dissolved-oxygen (DO) fluxes at Camp Far West Reservoir

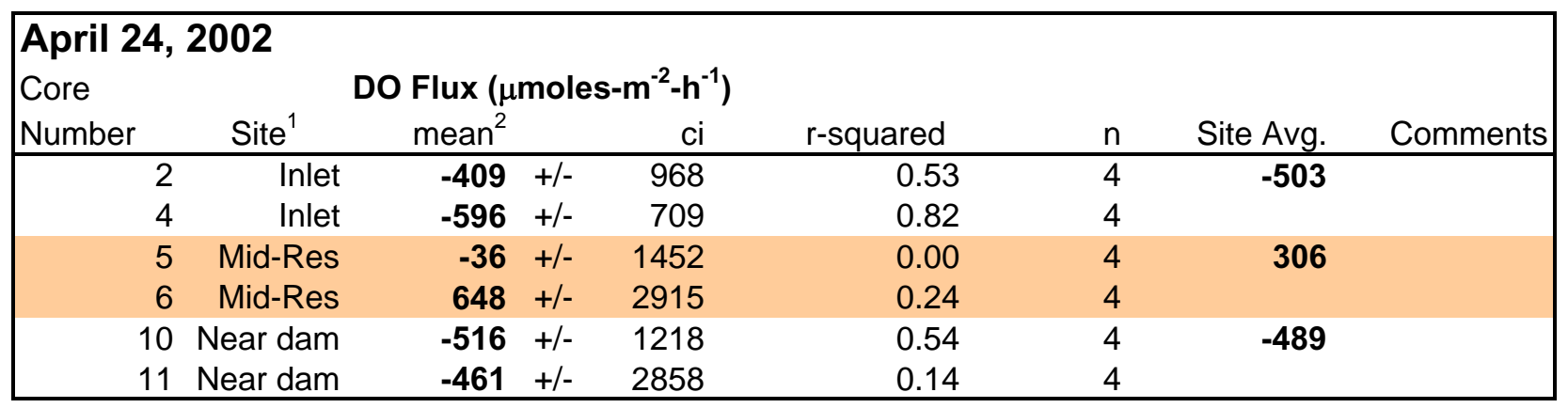

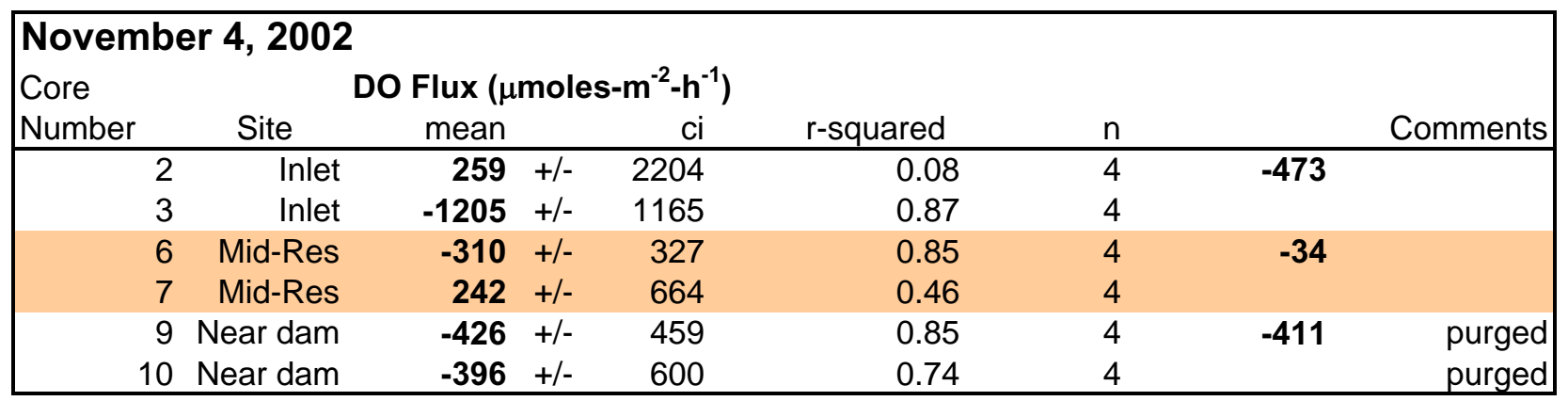

${ }^{1}$ Definitions for abbreviations used in this table:

$\begin{array}{ll}\text { Inlet }= & \text { Bear River inlet site } \\ \text { Mid-Res }= & \text { mid-reservoir site } \\ \text { Near dam }= & \text { deep, near-dam site } \\ \mu \text { moles- } \mathrm{m}^{-2}-\mathrm{h}^{-1}= & \text { micromoles of dissolved oxygen per square meter per hour } \\ \mathrm{ci}= & \begin{array}{l}\text { 95-percent confidence interval } \\ \mathrm{r} \text {-squared }=\end{array} \\ \mathrm{n}= & \begin{array}{l}\text { coefficient of determination for flux regression } \\ \text { analytical replicates used in flux determination }\end{array}\end{array}$

${ }^{2}$ Negative fluxes indicate consumption by the sediment 
Table 11. Water-column concentrations for dissolved (0.2-micrometer filtered) trace metals from Camp Far West Reservoir

April 24, 2002

\begin{tabular}{|c|c|c|c|c|c|c|c|c|c|c|c|}
\hline \multirow{4}{*}{ Inlet $^{1}$} & & $\begin{array}{c}\text { Depth } \\
(\mathrm{m})\end{array}$ & \multirow{2}{*}{$\begin{array}{r}\mathbf{M n}^{\mathbf{2}} \\
(\mathrm{nM}) \\
13.0\end{array}$} & $\begin{array}{r}\mathbf{Z n} \\
(\mathrm{nM})\end{array}$ & $\begin{array}{r}\mathbf{C d} \\
(\mathrm{nM})\end{array}$ & $\begin{array}{r}\mathbf{N i} \\
(\mathrm{nM})\end{array}$ & $\begin{array}{r}\mathbf{C u} \\
(\mathrm{nM})\end{array}$ & $\begin{array}{r}\mathbf{P b} \\
(\mathrm{nM})\end{array}$ & $\begin{array}{r}\text { Co } \\
(n M)\end{array}$ & $\begin{array}{r}\mathbf{V} \\
(\mathrm{nM})\end{array}$ & \multirow{2}{*}{$\begin{array}{r}\mathbf{F e} \\
(\mathrm{nM}) \\
\mathrm{n} / \mathrm{a}\end{array}$} \\
\hline & Surface & 1 & & 6.0 & 0.033 & 17.0 & 29.1 & 0.031 & 0.57 & 12.8 & \\
\hline & Mid-depth & 14 & 23.4 & 8.6 & 0.023 & 19.0 & 13.4 & 0.037 & 0.44 & 9.5 & $\mathrm{n} / \mathrm{a}$ \\
\hline & Deep & 28 & 135.4 & 23.5 & 0.067 & 19.9 & 28.5 & 0.031 & 0.56 & 11.2 & $\mathrm{n} / \mathrm{a}$ \\
\hline \multirow[t]{3}{*}{ Mid-Res } & Surface & 1 & 7.5 & 6.7 & 0.033 & 16.1 & 30.1 & 0.047 & 0.56 & 13.8 & $\mathrm{n} / \mathrm{a}$ \\
\hline & Mid-depth & 12 & 12.0 & 38.9 & 0.078 & 19.5 & 40.6 & 0.053 & 0.57 & 11.5 & $\mathrm{n} / \mathrm{a}$ \\
\hline & Deep & 24 & 23.7 & 23.2 & 0.053 & 18.6 & 28.8 & 0.031 & 0.55 & 11.6 & $\mathrm{n} / \mathrm{a}$ \\
\hline \multirow[t]{3}{*}{ Near dam } & Surface & 1 & 8.0 & 8.2 & 0.038 & 16.3 & 29.6 & 0.047 & 0.52 & 12.7 & 660 \\
\hline & Mid-depth & 21 & 7.8 & 13.3 & 0.040 & 18.5 & 22.1 & 0.076 & 0.45 & 10.6 & 689 \\
\hline & Deep & 43 & 23.1 & 50.7 & 0.112 & 20.1 & 45.2 & 0.050 & 0.54 & 11.1 & 748 \\
\hline \multicolumn{12}{|c|}{ November 4, 2002} \\
\hline & & & Mn & Zn & Cd & $\mathbf{N i}$ & $\mathrm{Cu}$ & $\mathrm{Pb}$ & Co & V & $\mathrm{Fe}$ \\
\hline \multirow{4}{*}{ Near dam } & & & (nM) & (nM) & $(\mathrm{nM})$ & (nM) & $(\mathrm{nM})$ & $(\mathrm{nM})$ & $(\mathrm{nM})$ & $(\mathrm{nM})$ & $(\mathrm{nM})$ \\
\hline & Surface & 1 & 120,000 & 34.4 & 0.087 & 31.0 & 9.7 & 0.053 & 38.76 & 37.9 & 891 \\
\hline & Above oxycline & 4 & 121,000 & 124.7 & 0.355 & 58.0 & 66.0 & 4.347 & 52.50 & 101.6 & 12896 \\
\hline & Deep & 18 & 118,000 & 1878.7 & 0.383 & 4.4 & 11.3 & 0.518 & 30.92 & 40.3 & 1778 \\
\hline \multicolumn{3}{|c|}{ Near-dam site comparison ratios } & Mn & $\mathrm{Zn}$ & Cd & $\mathrm{Ni}$ & $\mathrm{Cu}$ & $\mathbf{P b}$ & Co & $\mathbf{V}$ & $\mathrm{Fe}$ \\
\hline Nov/Apr & Surface & & 15012.1 & 4.2 & 2.3 & 1.9 & 0.3 & 1.1 & 74.2 & 3.0 & 1.3 \\
\hline \multirow[t]{2}{*}{ ratio } & Middle & & 15468.9 & 9.3 & 9.0 & 3.1 & 3.0 & 57.3 & 116.0 & 9.6 & 18.7 \\
\hline & Deep & & 5120.3 & 37.1 & 3.4 & 0.2 & 0.2 & 10.3 & 57.2 & 3.6 & 2.4 \\
\hline \multirow{3}{*}{$\begin{array}{r}\text { Deep/Surface } \\
\text { ratio }\end{array}$} & April & & 2.9 & 6.2 & 2.9 & 1.2 & 1.5 & 1.1 & 1.0 & 0.9 & 1.1 \\
\hline & November & & 1.0 & 54.6 & 4.4 & 0.1 & 1.2 & 9.8 & 0.8 & 1.1 & 2.0 \\
\hline & Temporal ratio $^{3}$ & & 0.3 & 8.8 & 1.5 & 0.1 & 0.8 & 9.2 & 0.8 & 1.2 & 1.8 \\
\hline
\end{tabular}

${ }^{1}$ Definitions for abbreviations used in this table:

$\begin{array}{ll}\text { Inlet }= & \text { Bear River inlet site } \\ \text { Mid-Res }= & \text { mid-reservoir site } \\ \text { Near dam }= & \text { deep, near-dam site } \\ \text { nM } & \text { nanomoles per liter }\end{array}$

${ }^{2}$ In the interest of simplicity, confidence intervals are not given for these data. For general reference, tabulated concentrations reflect the mean of at least 4 analytical replicates with a 95 -percent confidence interval $10 \%$ or less of the mean.

${ }^{3}$ Temporal ratio $=$ the deep/surface ratio in November divided by the deep/surface ratio in April;

this is used to demonstrate the temporal increase in concentration at depth relative to the surface. 
Table 12. Implications for Upstream Management

Water Column Dissolved Zinc Gradients ${ }^{1}$

\begin{tabular}{|c|c|c|c|c|c|c|c|c|}
\hline Date & $\begin{array}{l}\text { Bottom-water } \\
\text { Depth (m) }\end{array}$ & $\begin{array}{r}\text { Bottom-water } \\
\mathrm{Zn}(u \mathrm{M})\end{array}$ & $\begin{array}{l}\text { Layer Top } \\
\text { Depth (m) }\end{array}$ & $\begin{array}{r}\text { Layer Top } \\
\text { Zn (uM) }\end{array}$ & $\begin{array}{r}\Delta C \\
(u M)\end{array}$ & $\begin{array}{r}\Delta \mathbf{z} \\
(\mathrm{m})\end{array}$ & $\begin{array}{r}\Delta C / \Delta z \\
\left(u M-\mathrm{cm}^{-1}\right)\end{array}$ & $\begin{array}{r}\text { Flux } \\
\text { (umole } \mathrm{m}^{-2} \mathrm{~h}^{-1} \text { ) }\end{array}$ \\
\hline $4 / 24 / 2002$ & 45 & 0.050 & 1 & 0.008 & 0.043 & 44 & $9.73 \mathrm{E}-06$ & $3.5 \mathrm{E}-02$ \\
\hline $11 / 4 / 2002$ & 19 & 1.878 & 16 & 0.125 & 1.752 & 3 & $5.84 \mathrm{E}-03$ & $2.1 \mathrm{E}+01$ \\
\hline
\end{tabular}

Back Calculation of Pore-water Zinc Concentration ${ }^{3}$

\begin{tabular}{|c|c|c|c|c|}
\hline Date & $\begin{array}{r}\text { Flux } \\
\left(\mu \text { mole } \mathrm{m}^{-2} \mathrm{~h}^{-1}\right) \\
\end{array}$ & $\begin{array}{r}\text { Layer Thickness } \\
(\mathbf{c m})\end{array}$ & $\begin{array}{r}\Delta \mathrm{C} \\
(\mu \mathrm{M})\end{array}$ & $\begin{array}{l}\text { Estimated Pore-water } \\
\text { Concentrations }(\mu \mathrm{M})\end{array}$ \\
\hline $4 / 24 / 2002$ & $3.5 \mathrm{E}-02$ & 2 & 0.2 & 0.2 \\
\hline $11 / 4 / 2002$ & $2.1 \mathrm{E}+01$ & 2 & 116.8 & 118.7 \\
\hline
\end{tabular}

${ }^{1}$ A vertical eddy diffusivity of $0.1 \mathrm{~cm}^{2} \mathrm{~s}^{-1}$ was assumed (Mortimer, 1942; Lewis, 1982; Imberger, 1998).

${ }^{2}$ Definitions for abbreviations used in this table:

$$
\begin{array}{ll}
\mathrm{m}= & \text { meter } \\
\mu \mathrm{M}= & \text { micromoles per liter } \\
\mathrm{cm}= & \text { centimeter } \\
\mathrm{m}^{2}= & \text { square meter } \\
\mathrm{h}= & \text { hour } \\
\Delta \mathrm{C}= & \text { change in concentration } \\
\Delta \mathrm{z}= & \text { change in depth }
\end{array}
$$

\footnotetext{
${ }^{3}$ Diffusion coefficient of $1 \times 10^{-5} \mathrm{~cm}^{2} \mathrm{~s}^{-1}$ was assumed (Li and Gregory, 1974).
} 